\author{
UNIVERSIDADE DE SÃO PAULO \\ FACULDADE DE FILOSOFIA, LETRAS E CIÊNCIAS HUMANAS \\ DEPARTAMENTO DE GEOGRAFIA \\ PROGRAMA DE PÓS-GRADUAÇÃO EM GEOGRAFIA HUMANA
}

\title{
ZONEAMENTO ANTRÓPICO-AMBIENTAL DO MUNICÍPIO DE IPORÃ DO OESTE-SC: CONTRIBUIÇÃO PARA A REFLEXÃO E TOMADA DE DECISÕES NO ÂMBITO DAS MICROBACIAS HIDROGRÁFICAS
}


UNIVERSIDADE DE SÃO PAULO

FACULDADE DE FILOSOFIA, LETRAS E CIÊNCIAS HUMANAS

DEPARTAMENTO DE GEOGRAFIA

PROGRAMA DE PÓS-GRADUAÇÃO EM GEOGRAFIA HUMANA

\section{ZONEAMENTO ANTRÓPICO-AMBIENTAL DO MUNICÍPIO DE IPORÃ DO OESTE-SC: CONTRIBUIÇÃO PARA A REFLEXÃO E TOMADA DE DECISÕES NO ÂMBITO DAS MICROBACIAS HIDROGRÁFICAS}

Rosangela Lurdes Spironello

Tese apresentada ao Programa de Pós-Graduação em Geografia Humana, do Departamento de Geografia da Faculdade de Filosofia, Letras e Ciências Humanas da Universidade de São Paulo, para a obtenção do título de Doutor(a) em Ciências: Concentração: Geografia Humana.

Orientador: prof. Dr. Mário de Bisai 


\section{DEDICATÓRIA!}

Dedico esta pesquisa ao meu filho Matheus Henrique, luz da minha vida. 


\section{AGRADECIMENTOS}

- Ao Prof. Dr. Mário De Biasi, pela confiança depositada e por acreditar que esta caminha seria possível;

- Ao professor Dr. Roberto Cassol, pela paciência e encorajamento no momento de nossas conversas;

- À Universidade de São Paulo, Faculdade de Filosofia, Letras e Ciências Humanas por mais uma oportunidade de alçar novos vôos;

- Aos professores do Departamento de Geografia pelos ensinamentos e exemplos de trabalho sério;

- Aos meus pais e irmãos, pela força e carinho dedicados;

- Ao meu marido Nelson, presença constante nessa caminhada, obrigada pela paciência, compreensão e estímulo;

- Aos meus amigos e amigas Sandra, Liane, e Ivaniza pelo incentivo e força nesta caminhada;

- A minha grande amiga Isabel, profissional dedicada e sempre a disposição para a elaboração dos produtos cartográficos;

- A todos que de uma ou de outra forma colaboraram para que este objetivo fosse alcançado, meu muito obrigada. 


\section{RESUMO}

Dentre, os mecanismos voltados ao planejamento ambiental na atualidade e possíveis de serem implantados na gestão territorial, o Zoneamento-AntrópicoAmbiental tem se mostrado como um instrumento estratégico nas tomadas de decisões, o qual busca compatibilizar o desenvolvimento socioeconômico e manter ou preservar a qualidade ambiental de um determinado território. Nesse contexto, a presente pesquisa teve como objetivo elaborar uma proposta de ZoneamentoAntrópico-Ambiental para o Município de Iporã do Oeste-SC, a partir da caracterização e análise dos fatores socioeconômicos e ambientais juntamente com as perspectivas da população local. O embasamento teórico foi fundamentado na abordagem sistêmica. Metodologicamente a pesquisa centrou-se na proposta de Libault (1971), o qual aborda os quatro níveis da pesquisa geográfica. Para a elaboração do Zoneamento-Antrópico-Ambiental do Município de Iporã do Oeste-SC, foram delimitadas duas microbacias hidrográficas com base no Projeto Microbacias II, a microbacia hidrográfica do Lajeado Pirapó (MHLP) e a microbacia Hidrográfica do Lajeado Esperança, (MHLE), as quais apresentaram particularidades (relevo, uso da terra e localização) e relevância socioeconômica para o contexto local. Os resultados compreenderam a elaboração de diferentes produtos cartográficos (uso da terra, declividade, hipsometria, legislação e conflitos ambientais), confeccionados a partir do software Spring 4.2.1. Tais produtos foram sobrepostos gerando três zonas de uso e ocupação para ambas as microbacias. As zonas definidas foram: Zona de Uso e Ocupação Moderada (ZUOM); Zona de Uso e Ocupação Restrita (ZUOR) e Zona de Uso e Ocupação Controlada (ZUOC). A ZUOR predomina nas duas microbacias com um total de $54,66 \%$ de $2.176,09$ ha da MHLP e, $41,96 \%$ de $2.823,85$ da MHLE. A partir daí, cada zona foi caracterizada, destacando as potencialidades e limitações existentes, gerando um cenário atual e a incentivar, a partir das perspectivas ou projetos elencados pela população residente em cada microbacia. A proposta pretende contribuir para a discussão e a reflexão sobre as formas atuais e potenciais de uso e ocupação do espaço, orientando as tomadas de decisões por parte dos planejadores e pesquisadores, juntamente com a comunidade local, visando assim, o desenvolvimento socioeconômico e o equilíbrio do sistema socioambiental como um todo.

Palavras-chave: zoneamento-antrópico-ambiental, planejamento ambiental, uso da terra. 


\begin{abstract}
Among, the mechanisms returned to the environmental planning at the present time and possible of they be implanted in the territorial administration, the zoning-entropicenvironmental has shown as a strategic instrument in the decisions-making, which it looks for compatibiling the socioeconomic development and to maintain or to preserve the environmental quality of a certain territory. In that context, to present research it had as objective elaborates a proposal of Zoning-Entropic-environmental for the Municipal district of Iporã of West-SC, starting from the characterization and analysis of the socioeconomic and environmental factors together with the perspectives of the local population. The theoretical basement was based in the systemic approach. Methodologically the research was centered in the Libault proposal (1971), which approaches the four levels of the geographical research. For the elaboration of the Zoning-Entropic-environmental of the Municipal district of Iporã of West-SC, two micro basin hydrographic were delimited with base in the Micro basins Project II, the micro basin hydrographic of Lajeado Pirapó (MHLP) and the micro basin Hydrographic of the Lajeado Esperança, (MHLE), which presented particularities (relieve, earth using and location) and socioeconomic relevance for the local context. The results understood the elaboration of different cartographic products (earth using, steepness, hypsometry, legislation and environmental conflicts), made starting from the software Spring 4.2.1. Such products were put upon generating three use areas and occupation for both micro basins. The defined areas were: Use Area and Moderate Occupation (ZUOM); Use Area and Restricted Occupation (ZUOR) and Use Area and Controlled Occupation (ZUOC). ZUOR prevails in the two micro basins with a total of $54,66 \%$ of $2.176,09$ of the MHLP and, 41 , and $96 \%$ of $2.823,85$ of MHLE. Since then, each area was characterized, detaching the potentialities and existent limitations, generating a current scenery and to motivate, starting from the perspectives or developed projects for the resident population in each micro basin. The proposal intends to contribute for the discussion and the reflection about the current forms and use potentials and occupation of the space, guiding the decisions-making on the part of the planners and researchers, together with the local community, seeking like this, the socioeconomic development and the balance of the system socio-environmental as a completely.
\end{abstract}

Key-words: zoning-entropic-environmental, environmental planning, earth using. 


\section{LISTA DE ILUSTRAÇÕES}

Figura 01 - Esquema de relações entre os elementos de um Geossistema proposto por Bertrand (1971)

Figura 02 - Conjunto de rochas basálticas, constituição geológica predominante da área de estudo. Corte no estrato, - proximidade da comunidade de Taipa Alta.

Figura 03 - (a) Vista da Serraria de Reinoldo Ruchel com moinho, carpintaria e beneficiamento de madeira (b) Serraria de Reinaldo Ruschel \& 50 Cia.

Figura 04 - Vista parcial do parque de exposições da Linha FAIC, Iporã no ano de 1972

Figura 05 - Madeireira Grasel - beneficiamento de madeiras, inaugurada em 1999.

Figura 06 - Móveis Indekol LTDA. Inaugurada em 1999

Figura 07 - Metalúrgica Querência-fabricação de esquadrias em geral. Inaugurada no ano de 2000

Figura 08 - (a) Canteiro com mudas de fumo cultivadas para posterior plantio e (b) Vista parcial de uma área de fumo plantada 57

Figura 09 - Produção de frangos em sistema de parceria................................ 59

Figura 10 - Criação de gado de leite. 59

Figura 11 - Fluxograma envolvendo as etapas metodológicas para a elaboração da proposta de Zoneamento-Antrópico-Ambiental para as microbacias hidrográficas do Lajeado pirapó e Lajeado Esperança.

Figura 12 - Mapa de uso da terra do Município de Iporã do Oeste - 1978........ 75

Figura 13 - Mapa de uso da terra do Município de Iporã do Oeste - 1997........ 77

Figura 14 - Mapa de uso da terra do Município de Iporã do Oeste - 2007........ 81

Figura 15 - Mapa clinográfico do Município de Iporã do Oeste - SC................... 83

Figura 16 - Mapa das microbacias hidrográficas do Município de Iporã do Oeste-SC

Figura 17 - Produção de pêssego na microbacia do Lajeado Pirapó, Iporã do Oeste-SC. 
Figura 18 - Área florestada na microbacia do Lajeado esperança, Iporã do Oeste-SC

Figura 19 - (a) produção de milho (b) produção de fumo na microbacia do Lajeado esperança

Figura 20 - Mapa de uso da terra da microbacia hidrográfica do Lajeado Pirapó-Iporã do Oeste-SC

Figura 21 - Mapa de uso da terra da microbacia hidrográfica do Lajeado Esperança-Iporã do Oeste-SC

Figura 22 - Mapa clinográfico da microbacia hidrográfica do Lajeado PirapóIporã do Oeste-SC

Figura 23 - Mapa clinográfico da microbacia hidrográfica do Lajeado Esperança-Iporã do Oeste-SC

Figura 24 - Mapa hipsométrico da microbacia hidrográfica do Lajeado PirapóIporã do Oeste-SC

Figura 25 - Mapa hipsométrico da microbacia hidrográfica do Lajeado Esperança-Iporã do Oeste-SC

Figura 26 - Mapa de legislação da microbacia hidrográfica do Lajeado Pirapó-Iporã do Oeste-SC

Figura 27 - Área de cultivo de milho até próximo a margem esquerda do Lajeado Pirapó, no Município de Iporã do Oeste-SC.

Figura 28 - Mapa de conflitos ambientais na microbacia hidrográfica do Lajeado Pirapó-Iporã do Oeste-SC.

Figura 29 - Mapa de legislação da microbacia hidrográfica do Lajeado Esperança-Iporã do Oeste-SC

Figura 30 - Mapa de conflitos ambientais na microbacia hidrográfica do Lajeado Esperança-Iporã do Oeste-SC

Figura 31 - Mapa de zonas homogêneas da microbacia hidrográfica do Lajeado Pirapó-Iporã do Oeste-SC.

Figura 32 - Mapa de zonas homogêneas da microbacia hidrográfica do Lajeado Esperança-Iporã do Oeste-SC. 


\section{LISTA DE TABELAS}

Tabela 01 - População por faixa etária no Município de Iporã do Oeste no

Tabela 02 - Tabela 02 - Distribuição das classes de uso da terra no Município de Iporã do Oeste no ano de 1978.

Tabela 03 - Distribuição das classes de uso da terra no Município de Iporã do Oeste no ano de 1997

Tabela 04 - Classes de uso da terra no Município de Iporã do Oeste nos períodos de 1978, 1997 e 2007.

Tabela 05 - Classes de declividade do Município de Iporã do Oeste-SC.

Tabela 06 - Uso da terra na microbacia hidrográfica do Lajeado Pirapó, Município de Iporã do Oeste-SC

Tabela 07 - Classes de declividades nas microbacias hidrográficas dos Lajeados Pirapó e Esperança, Município de Iporã do Oeste-SC...

Tabela 08 - Classes hipsométricas da microbacia hidrográfica do Lajeado

Pirapó, Município de Iporã do Oeste-SC.

Tabela 09 - Classes hipsométricas da microbacia hidrográfica do Lajeado Pirapó, Município de Iporã do Oeste-SC.

Tabela 10 - Zonas homogêneas delimitadas na microbacia hidrográfica do Lajeado Pirapó, Município de Iporã do Oeste-SC.

Tabela 11 - Zonas homogêneas delimitadas na microbacia hidrográfica do Lajeado Pirapó, Município de Iporã do Oeste-SC. 


\section{LISTA DE QUADROS}

Quadro 01 - Culturas temporárias no Município de Iporã do Oeste no ano de 2002.

Quadro 02 - Número de estabelecimentos por tamanho no período compreendido entre 1975 e 1995 no Município de Iporã do Oeste$\mathrm{SC}$

Quadro 03 Classes de declividade definidas para a pesquisa

Quadro 04 - Uso da terra X Áreas de Preservação Permanente na microbacia hidrográfica do Lajeado Pirapó, Município de Iporã do Oeste-SC.

Quadro 05 - Uso da terra X Áreas de Preservação Permanente na microbacia hidrográfica do Lajeado Esperança, Município de Iporã do OesteSC

Quadro 06 - Caracterização da zona de uso e ocupação moderada na microbacia hidrográfica do Lajeado Pirapó-Iporã do Oeste-SC..........

Quadro 07 - Caracterização da zona de uso e ocupação restrita na microbacia hidrográfica do Lajeado Pirapó-Iporã do Oeste-SC

Quadro 08 - Caracterização da zona de uso e ocupação controlada na microbacia hidrográfica do Lajeado Pirapó-Iporã do Oeste-SC

Quadro 09 - Proposta de Zoneamento-Antrópico-Ambiental para a ZUM na microbacia hidrográfica do Lajeado Pirapó-Iporã do Oeste-SC.

Quadro 10 - Proposta de Zoneamento-Antrópico-Ambiental para a ZUR na microbacia hidrográfica do Lajeado Pirapó-Iporã do Oeste-SC

Quadro 11 - Proposta de Zoneamento-Antrópico-Ambiental para a ZUC na microbacia hidrográfica do Lajeado Pirapó-Iporã do Oeste-SC..........

Quadro 12 - Caracterização da zona de uso e ocupação moderada na microbacia hidrográfica do Lajeado Esperança-Iporã do Oeste-SC...

Quadro 13 - Caracterização da zona de uso e ocupação controlada na microbacia hidrográfica do Lajeado Esperança-Iporã do Oeste-SC...

Quadro 14 - Caracterização da zona de uso e ocupação restrita na microbacia hidrográfica do Lajeado Esperança-Iporã do Oeste-SC...

Quadro 15 - Proposta de Zoneamento-Antrópico-Ambiental para a ZUOM na microbacia hidrográfica do Lajeado Esperança-Iporã do Oeste-SC... 
Quadro 16 - Proposta de Zoneamento-Antrópico-Ambiental para a ZUOR na microbacia hidrográfica do Lajeado Esperança-Iporã do Oeste-SC... 145

Quadro 17 - Proposta de Zoneamento-Antrópico-Ambiental para a ZUOC na microbacia hidrográfica do Lajeado Esperança-Iporã do Oeste-SC... 148 


\section{SUMÁRIO}

2 - EMBASAMENTO TEÓRICO E METODOLÓGICO.

2.1 - PLANEJAMENTO E A QUESTÃO AMBIENTAL: REFLEXOS DA OCUPAÇÃO HISTÓRICA.

2.2 - PLANEJAMENTO SOCIOESPACIAL E SUA RELAÇÃO COM A GEOGRAFIA

2.2.1 - Zoneamento-Antrópico-Ambiental como proposta metodológica de gestão do espaço geográfico do Município de Iporã do Oeste-SC. 28

2.3 - O GEOSSISTEMA COMO ABORDAGEM TEORICO-METODOLOGICA NAS PESQUISA DE PLANEJAMENTO SOCIO ESPACIAL

3 - CARACTERIZAÇÃO GERAL DA ÁREA DE ESTUDO.

3.1 - FATORES FÍSICOS, SOCIAIS E ECONÔMICOS DA ÁREA DE ESTUDO

3.2 - CONSIDERAÇÕES Á RESPEITO DO PROCESSO DE OCUPAÇÃO DO ESPAÇO CATARINENSE.

3.3 - PROCESSO DE FORMAÇÃO TERRITORIAL E CARACTERIZAÇÃO SOCIECONOMICA DO MUNICÍPIO DE IPORÃ DO OESTE-SC.

4 - MATERIAIS E MÉTODOS. 62

4.1 - MATERIAIS. 62

4.2 - PROCEDIMENTOS METODOLÓGICOS. 62

4.2.1 - Elaboração dos mapas de uso da terra do Município de Iporã do Oeste-SC.

4.2.2 - Elaboração dos mapas de uso da terra das microbacias hidrográficas do Lajeado Pirapó e Lajeado Esperança

4.2.3 - Elaboração do mapa clinográfico do Município de Iporã do OesteSC.

4.2.4 - Elaboração dos mapas clinográficos das microbacias hidrográficas do Lajeado Pirapó e Lajeado Esperança 
4.2.5 - Elaboração dos mapas hipsométricos das microbacias 68 hidrográficas do Lajeado Pirapó e Lajeado Esperança.

4.2.6 - Elaboração dos mapas de legislação das microbacias hidrográficas do Lajeado Pirapó e Lajeado Esperança

4.2.7 - Elaboração dos mapas de conflitos ambientais das microbacias hidrográficas do Lajeado Pirapó e Lajeado Esperança

4.2.8 - Zoneamento-Antrópico-Ambiental (ZAA) das microbacias hidrográficas dos Lajeados Pirapó e Lajeado Esperança..

5 - ANÁLISES E DISCUSSÕES DOS RESULTADOS

73

5.1 - USO DA TERRA NO MUNICÍPIO DE IPORÃ DO OESTE-SC. 73

5.2 - ZONEAMENTO-ANTRÓPICO-AMBIENTAL DAS MICROBACIAS HIDROGRÁFICAS DO MUNICIPIO DE IPORÃ DO OESTE-SC.

5.2.1 - Aspectos socioeconômicos e ambientais das microbacias hidrográficas do Lajeado Pirapó (MHLP) e Lajeado Esperança (MHLE)..

5.2.2 - mapeamento do uso da terra e de declividades das microbacias hidrográficas do Lajeado Pirapó e Lajeado Esperança.....

5.2.2.1 - Áreas de preservação Permanente (APP) X uso da terra na microbacia hidrográfica do Lajeado Pirapó.

5.2.2.2 - Áreas de preservação Permanente (APP) X uso da terra na microbacia hidrográfica do Lajeado Esperança.

5.3 - PROPOSTA DE ZONEAMENTO-ANTRÓPICO-AMBIENTALPARA AS MICROBACIAS HIDROGRÁFICAS DO LAJEADO PIRAPÓ E LAJEADO ESPERANÇA

5.3.1 - Zoneamento-Antrópico-Ambiental da microbacia hidrográfica do Lajeado Pirapó.

5.3.1.1 - Zonas homogêneas $X$ perspectivas da população na microbacia hidrográfica do Lajeado Pirapó.

5.3.2 - Zoneamento-Antrópico-Ambiental da microbacia hidrográfica do Lajeado Esperança.

5.3.2.1 - Zonas homogêneas $X$ perspectivas da população na microbacia hidrográfica do Lajeado Esperança..... 
6 - CONSIDERAÇÕES FINAIS.

152

BIBLIOGRAFIA 


\section{1 - INTRODUÇÃO}

O espaço geográfico mundial, em seu conjunto, vem sendo continuamente transformado pelas ações e atividades humanas. As transformações socioespaciais resultam na necessidade de organizar o espaço geográfico diante do acelerado processo de globalização. Neste contexto, se inserem não somente as nações e os estados, mas especialmente, as regiões e os municípios, os quais necessitam organizar-se internamente para participar das mudanças ditadas pelas políticas socioeconômicas, que ora são impelidas pela globalização.

Com a necessidade de atender a demanda de recursos naturais e/ou econômicos para a população, que é crescente, estratégias de desenvolvimento foram implantadas em grande escala, até meados da década de 1970, sem levar em consideração as conseqüências negativas, principalmente com relação ao meio ambiente.

Nas últimas décadas, a temática ambiental tornou-se um dos principais focos de discussão não apenas entre os pesquisadores, os planejadores e os políticos, mas também em todos os segmentos da sociedade. Esta discussão estimulou, conforme Christofoletti (1999, p. 157), "a necessidade de se conciliar as atividades socioeconômicas com as potencialidades e restrições ambientais...", visando a recuperação e manutenção dos recursos naturais para as gerações futuras. Foi dado início efetivamente aos debates sobre o tema em questão, e ter uma consciência maior sobre as implicações relacionadas ao crescimento demográfico, a demanda por novos espaços e a exploração dos recursos naturais.

Atualmente, sabe-se que o desafio maior é aliar o crescimento econômico à manutenção dos recursos naturais de forma adequada e racional. Esse desafio exige o devido conhecimento do espaço geográfico de forma eficiente, e que possibilite a implantação de políticas de planejamento tanto ambiental quanto produtivo, para que as tomadas de decisões sejam também adequadas às propostas e objetivos de conservação do meio físico, econômico e social. Para isso, é necessário que as pesquisas e trabalhos sejam desenvolvidos em conjunto, aliando as mais diversas áreas do conhecimento, entre elas a Geografia, que sempre teve o espaço geográfico como objeto de estudo e está, indubitavelmente, ligada com esta problemática. 
Neste sentido do conhecimento geográfico, ressalta-se a importância da relação entre a Geografia e a Cartografia, por meio das diversas técnicas e métodos de representações dos fenômenos espaciais.

A utilização de produtos cartográficos, especificamente nas pesquisas ambientais, possibilita uma sistematização do conhecimento geográfico, pois entende-se que os mapas não são apenas produtos cartográficos onde nos quais são registrados e armazenados os dados e as informações. Os mapas também são instrumentos de pesquisas fundamentais que servem de apoio ao planejamento adequado do espaço geográfico em suas diferentes escalas.

Todavia, o sensoriamento remoto e os Sistemas de Informações Geográficas - SIG, têm contribuído de forma significativa para o avanço do conhecimento, com a elaboração de produtos que nos permitem realizar inúmeras análises e, posteriormente, obter uma síntese da realidade pesquisada. Assim, os dados e/ou informações são extraídos de tecnologias ligadas ao Geoprocessamento, ou seja, de imagens orbitais e suborbitais onde são adquiridos, armazenados e manipulados de forma cada vez mais rápida e precisa. Dessa forma, trata-se de recursos que estão auxiliando no desenvolvimento de programas de planejamento em diferentes escalas.

Entende-se também que o desenvolvimento tecnológico é necessário para o avanço do conhecimento. Porém, de nada adianta elaborar projetos e pesquisas: "Se os planejadores desconhecerem as implicações da qualidade, grandeza e dinâmica dos elementos ambientais..."Christofoletti (1999, p. 165). Por isso, se faz necessário pensar e planejar o espaço geográfico a partir da realidade local, conhecendo-se os aspectos físicos, socioeconômicos, culturais, ambientais e políticos. Para que isso seja possível, a participação efetiva da comunidade no planejamento e nas tomadas de decisões é fundamental, para que se tenha melhores condições de vida e um aproveitamento adequado dos recursos naturais renováveis ou não.

Sabe-se, no entanto, que a maioria dos problemas socioambientais decorre da falta de um planejamento estratégico, ou seja, de medidas que contemplem a dinâmica socioespacial. Neste sentido, a identificação de zonas homogêneas numa determinada área é fundamental para instrumentalizar, otimizar e orientar as ações de manejo e gestão dos recursos naturais, além de apoiar na elaboração de objetivos e diretrizes para o planejamento e para as políticas públicas em qualquer 
esfera de governo, sendo, neste projeto, veiculado de forma mais direta ao governo municipal.

Conforme esclarece Missio (2003, p. 12):

A elaboração e proposição de diretrizes estratégicas, relacionadas a um projeto específico ou a um espaço delimitado política ou morfologicamente, fornecem indicadores para as tomadas de decisão, pois têm o objetivo de prevenir a dilapidação das potencialidades do ambiente físico, fornecendo informações adequadas sobre as possíveis conseqüências nefastas que poderão se desenvolver se tais diretrizes não forem implementadas.

Diante dessa reflexão, a presente pesquisa busca o entendimento das diversas formas de uso e ocupação do espaço e, tem como temática central, o Zoneamento-Antrópico-Ambiental como proposta de gestão e ordenamento territorial do Município de Iporã do Oeste-SC, tendo como objeto de estudo, as microbacias hidrográficas do Lajeado Pirapó e do Lajeado Esperança.

Assim, buscou-se investigar o espaço geográfico do Município de Iporã do Oeste, Estado de Santa Catarina, em face da escassez de estudos e pesquisas com relação à utilização dos recursos naturais, bem como, da organização econômica e social. A ausência de conhecimento sobre as potencialidades ambientais, econômicas e sociais desse município dificulta o planejamento e a tomada de decisões. Dentre as raras informações conhecidas sobre o referido município, faz parte, o mapeamento de uso da terra realizado por Spironello $(2001,2002)$. A autora constatou que o Município de Iporã do Oeste possui hoje uma cobertura florestal (mata nativa e exótica) de 5.625,43 ha, o que corresponde a $28,1 \%$ da área do município, considerando-se que a sua área total abrange 20.009,62 ha. Ainda foi verificado pela autora a intensificação no uso e ocupação da terra pelas atividades destinadas à agricultura no município em áreas de relevo acentuado, restringindo o seu uso.

Considerando que o município tem na produção de milho, de feijão, de trigo e de fumo, e na criação de aves, de suínos e de bovinos de leite a base de sua economia, necessário se faz pensar em medidas mitigadoras para corrigir os impactos ambientais que ora ocorrem neste espaço. 
Conhecendo a realidade da área de estudo, ressalta-se a necessidade de encontrar caminhos para potencializar os fatores socioeconômicos e ambientais, com vistas a reduzir os conflitos existentes nessas três esferas. Com base nesse entendimento e na problematização do tema em estudo, a presente pesquisa tem como objetivo geral: elaborar uma proposta de zoneamento a partir de elementos físicos e antrópicos, para o Município de Iporã do Oeste a partir de microbacias; e como objetivos específicos apresenta-se os seguintes: - identificar, caracterizar e analisar os diferentes usos da terra e os conflitos ambientais decorrentes principalmente da ação antrópica; elaborar um banco de dados geográfico em formato digital, com informações referentes aos diferentes usos da terra e potencialidades do meio físico, para servir de subsídios a diversas pesquisas de planejamento ambiental e econômico; definir unidades geográficas espaciais viáveis, visando o desenvolvimento e o crescimento local, no âmbito das microbacias hidrográficas inseridas no Município de Iporã do Oeste; indicar em cada unidade geográfica espacial delimitada, a natureza e a intensidade de programas e ações necessários de recuperação de áreas potencialmente conflitantes; contribuir com subsídios ao debate e a discussão sobre a aplicabilidade de políticas de manejo e gestão adequada do espaço geográfico do município em questão.

Essa proposta servirá de instrumento de planejamento territorial do município. Assim, a elaboração de diferentes produtos cartográficos como, cartas de uso da terra, clinográfica, hipsometria, legislação, entre outras, apoiarão ações e estratégias à implementação de políticas de gerenciamento dos recursos naturais e econômicos de forma adequada e racional. Também auxiliará na elaboração futura de um plano diretor agrícola para o município, proposta inédita no Estado de Santa Catarina.

Com isso, a população urbana e em especial a rural será beneficiada, e suas atividades poderão ser direcionadas, objetivando novas alternativas de renda, visando o desenvolvimento local sem que o meio físico sofra conseqüências danosas. 


\section{2 - EMBASAMENTO TEÓRICO E METODOLÓGICO}

\section{1 - PLANEJAMENTO E A QUESTÃO AMBIENTAL: REFLEXOS DA OCUPAÇÃO HISTÓRICA}

No contexto atual, falar de planejamento e análise ambiental requer necessariamente que se faça uma retrospectiva sobre a formação socioespacial e a questão ambiental no Brasil. Pois, através de uma análise espaço-temporal, tem-se condições de entender a dinâmica das relações que se estabelecem entre o homem x natureza e a própria apropriação do espaço pela sociedade.

Vale ressaltar, porém, que mesmo trabalhando as questões ambientais em diferentes níveis de escala, e sabendo que os elementos físicos e humanos se interrelacionam é importante, ter bem claro que cada realidade é sentida e percebida de forma particular.

Nesse sentido, Becker (1999, p. 310), em suas colocações, deixa claro que: "Em uma abordagem de caráter geográfico referente à questão ambiental, tendo como base o território brasileiro, deve partir daqueles processos sócioespaciais que a essa escala se mostram responsáveis pelos graves problemas ambientais que ali se configuram e que se mostram cada vez mais fortes nos dias atuais" [grifo nosso].

É notório que muitos dos problemas socioambientais no Brasil têm seus reflexos na própria história. História esta de exploração e apropriação do espaço, com objetivos meramente econômicos e políticos, elencados principalmente por uma elite dominante, a qual detém o poder.

Nesse sentido, compreende-se que o Estado-nação se coloca como ator fundamental no processo de apropriação da natureza. Essa apropriação é percebida de forma bem evidente através da delimitação de fronteiras entre diferentes Estadosnações. Assim, de acordo com Becker (1999), as relações sociais que se estabelecem dentro de um determinado território é que irão desvendar como, por que, por quem e para quem a natureza é apropriada.

A história do Brasil nos mostra que no século $\mathrm{XVI}$, o que movia o país era a conquista de novos espaços e a apropriação dos recursos naturais de uso da terra. 
O pau-brasil naquele momento histórico foi o principal alvo do "saque" por parte dos colonizadores.

A partir de 1530, o modo de apropriação do espaço brasileiro ganha uma nova característica, o sistema de plantation, voltado para a exportação. O principal produto produzido era a cana-de-açucar, a qual tinha grande aceitação no mercado europeu (BECKER, 1999).

Outras características marcaram a formação socioespacial do território brasileiro, vinculando a questão ambiental, ainda na fase colonial: a forte concentração de terras, o tratamento exploratório dos nativos e a desigualdade na distribuição da população. Isso encontra-se refletido na nossa história até os dias atuais.

No século XIX, em meio a grandes acontecimentos como a Revolução Industrial e a difusão de idéias liberais, novas concepções foram se firmando no contexto global e o Brasil, consequentemente, passou a sentir os resultados dessas mudanças. Em função das pressões para que ocorresse a abolição da escravatura, foi promulgada a Lei de Terras em 1850. Esta Lei foi implantada com o objetivo de suprir a necessidade de mão-de-obra naquele momento de transição do trabalho escravo para o trabalho assalariado, favorecendo o poder e o domínio dos grandes latifundiários, conforme nos esclarece Becker (1999).

Conforme destaca a autora acima citada, o estado nesta época impedia a apropriação da terra, o que transformava-a numa mercadoria, assim, quem quisesse ter acesso a mesma, poderia fazê-lo através da compra. Essa atitude tornava praticamente impossível a aquisição de terras por parte dos imigrantes, permanecendo desta forma, como rélis empregados ou assalariados dos grandes latifundiários.

Situação diferente ocorre na Região Sul do Brasil, onde o governo por questões estratégicas e geopolíticas, passa a incentivar a ocupação do espaço geográfico, partindo das áreas florestadas do Planalto Meridional, constituindo as pequenas propriedades, as quais são as características principais da estrutura fundiária dessa região.

Já na década de 30, do século passado, em meio a uma crise mundial, percebe-se uma nova reorganização do espaço brasileiro, assumindo características de urbano-industrial, onde a região sudeste assume o posto de pólo industrial do país. Esse avanço urbano-indusrial se estende para as décadas seguintes de nossa 
história, mostrando, por outro lado, a fragilidade da burguesia industrial. Dessa forma, o Estado passa a centralizar o poder, construindo estradas, instalando novas indústrias, ampliando a rede de transportes e comunicações, mas sempre preservando os interesses das empresas agroexportadoras (BECKER, 1999).

Com isso crescem as cidades, bem como a demanda por produtos e bens de consumo, forçando a expansão de áreas cultiváveis, principalmente para o interior do país. Essa busca por áreas para cultivo passa a gerar sérias conseqüências aos recursos naturais, uma vez que o desmatamento de grandes áreas de florestas, como a da Amazônia, começa ser pleiteado de forma indiscriminada, sem planejamento prévio.

Voltando-se à região Sul do Brasil, mais precisamente no Estado de Santa Catarina, as características de ocupação do espaço, pelos colonizadores, começam a se moldar pelo litoral, se estendendo para o Planalto e por fim o Oeste Catarinense, com a vinda dos colonizadores europeus, alemães e italianos. Vale lembrar, porém, que esta porção do espaço já era ocupada anteriormente por indígenas, das tribos Kaingangs e Xoklengs, as quais foram praticamente dizimadas com o processo de colonização. Também foi muito significativa a presença dos caboclos nessa região. A relação que estas etnias tinham com a natureza e com os recursos naturais era de harmonia, uma vez que, se vivia inicialmente da caça e da pesca, com a prática de uma agricultura de subsistência, o sentimento capitalista não se encontrava empregnado neles.

Depois que os "gringos"1 chegaram na região do oeste catarinense, o espaço geográfico passou a sofrer gradativas alterações. O desejo de encontrar a terra prometida e buscar o desenvolvimento, com melhores condições de vida, estava bastante presente.

Começou-se então o processo de desmatamento e conseqüente implantação de serrarias para beneficiamento da madeira, a qual era exportada também para a Argentina, através do Rio Uruguai. Paralelamente, houve a introdução da prática agrícola de forma mais intensa, produzindo diversos produtos como o feijão, o milho, a mandioca, a batata entre outros. Atualmente os recursos naturais encontram-se depredados e a área de florestas no Estado de Santa Catarina não ultrapassa os $20 \%$.

\footnotetext{
${ }^{1}$ Denominação dada pelo escritor Poli em seu artigo "O caboclos" publicado em 1995 na revista CEON.
} 
Diante da problemática social, econômica e ambiental, que se configura não só no estado de Santa Catarina, mas também em todo o Brasil, percebe-se que o contingente de pessoas que saem das áreas rurais em direção aos grandes centros urbanos, bem como para outras regiões através das fronteiras agrícolas, está aumentando gradativamente. Estados como o Pará, Rondônia e Acre, bem como em áreas do cerrado brasileiro, atualmente, são os alvos de muitos grupos de famílias. Estes espaços são propícios para a extração de madeira, pela sua abundância, prática da agricultura e a criação de gado.

Isso deixa claro que a falta de oportunidade e de planejamento, faz com que muitas pessoas se desloquem de um lugar para outro na busca de melhores condições de vida, o que na maioria das vezes, acaba se tornando em opções frustradas, piorando ainda mais as condições sociais e econômicas.

É necessário que se mude esse contexto e se comece a pensar em estratégias coerentes de planejamento e gestão dos recursos naturais, para manter as pessoas em seus espaços de produção, tendo condições dignas de vida, para que no futuro outras pessoas possam também usufruir desses recursos que ainda existem.

\section{2 - PLANEJAMENTO SOCIOESPACIAL E SUA RELAÇÃO COM A GEOGRAFIA}

Planejar o espaço geográfico na busca de um ambiente equilibrado para os seres vivos sempre se fez presente na espécie humana, desde os povos nômades até as civilizações mais recentes. Com o passar do tempo, as necessidades e a demanda da população pelos recursos naturais foram aumentando, fazendo com que o homem se apropriasse ainda mais da natureza sem se preocupar com a sua depredação e conseqüências futuras.

$\mathrm{Na}$ pré-história, mesmo que instintivamente, os povos nômades se relacionavam com o espaço de uma forma menos comprometedora, isto é, utilizavam-se do solo, da água e da vegetação conforme havia a necessidade da sobrevivência, e o deslocamento de um lugar para outro permitia que a natureza se reconstituísse para fornecer novamente a alimentação à população.

Com a fixação do homem num determinado espaço, este teve que se organizar e "...ficar mais atento aos limites dos recursos disponíveis, bem como ao 
tempo que a natureza levava para a sua reposição" (FRANCO, 2001, p. 34). Assim, planejar o espaço e a utilização dos recursos naturais (como o solo, água, vegetação, etc...), passou a ser uma necessidade, principalmente pelo fato de estarem fixados num território. É importante destacar aqui, que planejar o espaço naquela época não considerava que, no futuro, o crescimento exagerado da população e o consumo em larga escala de tais recursos, levariam à depredação, esgotamento e a limitação dos mesmos.

Essa apropriação do espaço e da natureza como um todo se acentua a partir do momento em que o homem descobre novos territórios, com o advento das grandes navegações. Com isso, Franco (2001, p. 35), complementa dizendo que o homem perde a "...noção de escala de recursos, achando de maneira infantil, que poderia "gastar infinitamente". Conforme a autora citada, essa apropriação dos recursos naturais se acentua a partir do século XVII, e posteriormente com a Revolução Industrial.

Diante dessas colocações e certos de que nesse momento histórico tem-se uma realidade ambiental complexa, torna-se necessário pensar em se conservar e equilibrar o espaço geográfico de forma "sustentável"2 para que as gerações futuras possam usufruir de forma adequada os recursos naturais ainda existentes.

No entanto, é necessário criar uma consciência ecológica e ambiental com relação ao espaço ao qual o homem está inserido. Para tal, o homem precisa refletir sobre a sua atuação enquanto agente modificador do espaço geográfico, e entender também que o ato de planejar esse espaço requer um conhecimento mínimo sobre os elementos constituintes do mesmo, como sua organização econômica, social, ambiental, etc.

Mas afinal, o que significa planejar? A denominação do termo planejar vem do ato de designar, projetar, estabelecer plano, enfim, o planejamento é uma projeção das ações que se quer executar num determinado espaço e num determinado tempo, atendendo com isso, as necessidades de um público alvo ${ }^{3}$. Assim, o planejamento é fundamental porque ordena e orienta as tomadas de decisões, sejam no âmbito político, econômico, social e ambiental.

\footnotetext{
${ }^{2}$ Sustentável - entende-se e define-se o termo sustentável como sendo a forma uso de um espaço sem degradar o mesmo, garantindo a sobrevivência da população e das futuras gerações.

${ }^{3}$ Aurélio, B. H. F. (2004).
} 
Assim, uma pesquisa de planejamento deve levar em consideração alguns encaminhamentos lógicos, como: Identificações de necessidades e objetivos isto significa, fazer um levantamento das "...necessidades e aspirações da população, bem como levantar dados sobre os potenciais e as limitações dos fatores físico-topográficos por meio de diagnósticos participativos" (VIEIRA, 1995, p. 64). O mesmo autor ainda destaca que a identificação de problemas e alternativas são realizadas, tendo como base, no registro do que a população percebe, nas atitudes e valores concebidos dos diversos segmentos da sociedade envolvidos, desde empresas públicas, privadas, grupos políticos, organizações da sociedade civil e grupos informais.

Nesse sentido, a pesquisa não necessita ser tão exaustiva se há um conhecimento prévio do espaço a ser estudado, isto é, se o pesquisador conhece o lugar e tem uma bagagem teórica sobre o tema abordado e sobre a área a ser pesquisada, o processo de identificação, levantamento e análises dos dados pode se tornar mais rápida, e por que não eficiente, contribuindo para a tomada de decisões.

Posteriormente, deve-se levar em consideração a análise de problemas e busca de alternativas - isto pode ser realizado por meio da avaliação de impactos ambientais. A avaliação de impactos ambientais “... constitui-se em um conjunto de operações designadas para identificar, predizer, analisar e comunicar informações importantes, a respeito dos impactos relativos ao estado do meio ambiente e sobre a qualidade de vida das populações, causados por projetos, programas e até políticas de desenvolvimento regional mal elaborados". (VIEIRA, 1995, p. 66-67); implementação e monitoramento de estratégias regionais - conforme 0 autor citado, isso significa: “..internalizar a questão do planejamento - econômico ou ambiental - não só como uma tentativa de se adicionar mais um setor suplementar de política pública a um dispositivo institucional enrijecido em seus objetivos estratégicos, métodos de análise e intervenção, mas trata-se sim, em algo mais profundo. Implica no redirecionamento da própria organização dos sistemas produtivos e distributivos".

Assim, entende-se que o planejamento requer uma revisão constante das etapas, para que as ações sejam executadas de forma a atender aos objetivos propostos. Pois, conforme Ferreira (1994, p. 58) deixa claro que: "O difícil não é saber planejar. É conhecer o que se planeja”. 
Com base nessas colocações, pretende-se centrar o foco de nossa análise no planejamento ambiental, não significando que os demais setores de análise (territorial, social, político e econômico) ficarão de lado, pois sabe-se que estes fazem parte do processo de discussão, cada qual com sua parcela de contribuição, numa dinâmica espaço-temporal. Vale destacar, porém, que a Geografia como ciência exerce um papel significativo nessas discussões, por compreender e analisar o espaço geográfico de uma forma crítica e sistematizada.

Sabe-se, no entanto, que o termo "planejamento ambiental" tem sido utilizado de forma bastante expressiva pelos pesquisadores e profissionais que atuam na área, principalmente nas últimas décadas em função das constantes discussões referente à problemática ambiental. Porém, é importante deixar claro que para este termo são atribuídas inúmeras definições, em que cada autor o define e o estabelece de acordo com o objetivo da análise.

Nesse sentido, pode se destacar as contribuições de Silva e Santos (2004, p.223) quando os mesmos deixam claro que:

Planejamento ambiental é um processo contínuo que envolve coleta, organização e análise sistematizada das informações, por meio de procedimentos e métodos, para se chegar a decisões ou escolhas acerca das melhores alternativas para o aproveitamento dos recursos disponíveis em função de suas potencialidades, e com a finalidade de atingir metas específicas no futuro, tanto em relação aos recursos naturais quanto à sociedade.

Outra importante definição é trazida por Santos (2004, p. 28), quando a autora afirma que:

O planejamento ambiental fundamenta-se na interação e integração dos sistemas que compõem o ambiente. Tem o papel de estabelecer as relações entre os sistemas ecológicos e os processos da sociedade, das necessidades socioculturais a atividades e interesses econômicos, a fim de manter máxima integridade possível dos seus elementos componentes.

Nessa perspectiva, de acordo com a colocação, pode-se compreender que o planejamento ambiental é pensado e projetado dentro de uma abordagem holística 
do espaço, por relacionar e integrar todos os elementos da natureza e a própria sociedade.

Franco (2001, p. 35) considera que o planejamento ambiental:

...é todo o planejamento que parte da valoração e conservação das bases naturais de um dado território como base de auto-sustentação da vida e das interações que a mantém, ou seja, das relações ecossistêmicas.

A autora destaca também que o planejamento “...pressupõe três princípios de ação humana sobre os ecossistemas: os princípios da preservação, da recuperação e da conservação do meio ambiente" (2001, p. 36). O primeiro deles pressupõe que o espaço geográfico delimitado deva permanecer intocado pelo homem, servindo somente como áreas de reservas e banco genético para pesquisas futuras. Nesse contexto, podem-se citar o Pantanal e regiões da Amazônia, como espaços que mantêm um equilíbrio maior dos ecossistemas.

A recuperação ambiental são áreas que sofreram alterações por parte do homem e que necessitam ser recuperadas, como, por exemplo, mata ciliar degradada. E por fim, o princípio da conservação ambiental, pressupõe que o espaço geográfico pode ser utilizado pelo homem, desde que provoque o mínimo de degradação possível. Em outras palavras, pode se definir o termo conservação como a utilização racional de qualquer recurso natural, possibilitando que este garanta a sua auto sustentação ou renovação.

Dando seqüência, Botelho (1999) define planejamento ambiental como sendo um processo racional de tomada de decisões sobre um determinado espaço, sugerindo que se obtenha uma maior reflexão sobre todos os aspectos, sejam eles de ordem socioeconômica ou ambiental, os quais dão um norte para as ações futuras, tanto numa escala local ou até mesmo a global.

Novamente Botelho (1999), destaca que no planejamento ambiental, devese considerar e analisar os aspectos físicos geográficos, como o relevo, solo, geologia, hidrografia e vegetação, bem como os aspectos econômicos, políticos e sociais de um país, estado, região, município, etc. Nesse contexto, o planejamento ambiental, deve ser pensado e projetado no intuito de promover o desenvolvimento 
de um determinado território, sem que os recursos naturais e a qualidade ambiental sejam prejudicados.

Outra contribuição importante é trazida por Moraes (2002, p. 24), quando o mesmo diz que: "É impossível fazer planejamento ambiental sem uma articulação intersetorial no nível de governo inicialmente, não se pode pensar o manejo de uma determinada área sem levar em conta os planos e programas setoriais incidentes sobre ela". Por isso, planejar os espaços, respeitando as particularidades dos projetos e legislação, contribui significativamente para a adequação dos mesmos e a manutenção dos recursos naturais existentes.

A Lei no 6.938/81 menciona o termo qualidade ambiental e, para uma melhor compreensão desta toma-se o conceito adotado por Botelho \& Silva (2004, p. 154), quando os mesmos dizem que:

É preciso entender qualidade ambiental como reflexo da ação do homem sobre o espaço e seus componentes em um dado momento. [...] $A$ Qualidade ambiental deve ser encarada não só como somatório das qualidades de cada um dos componentes do meio, mas como condição essencialmente ligada à qualidade de vida das populações.

Portanto, há a necessidade de se pensar projetos nesse nível, por equipes multidisciplinares e interdisciplinares, para que todos os aspectos ou fatores possam ser considerados e avaliados, dentro de uma concepção holística, lembrando que estes devem estar amparados sob uma metodologia de análise.

Nessa perspectiva, a Geografia, como as demais ciências, por meio de seus métodos de abordagem, procura desenvolver as análises e promover as discussões, demonstrando uma preocupação iminente, principalmente no que diz respeito às questões ambientais, uma vez que o homem como parte integrante deste processo, necessita dos recursos naturais para sobreviver, promover a sua manutenção e a das gerações futuras. Assim sendo, quando se fala em questões ambientais “... é necessário pensar-se no todo (o natural e o social) e de que modo esse todo se manifesta na sociedade" (ROSS, 1995, p.66). Por isso, a necessidade de se compreender a realidade que nos cerca de forma abrangente, holística, numa perspectiva inter e multidisciplinar. 
Nesse preâmbulo, as projeções de ações para o futuro, vinculadas à natureza e a sociedade, devem estar inclusive atreladas a uma política de planejamento estratégico, a qual promova o desenvolvimento da sociedade minimizando os danos provocados aos recursos naturais.

Conforme esclarece Ross, (1995, p.66):

\begin{abstract}
Nesta direção é importante ressaltar que as análises ambientais na abordagem geográfica são excelente suporte técnico-científico para a elaboração dos Zoneamentos ambientais e Sócio-econômicos, que por sua vez dão suporte as políticas de planejamento [...] em qualquer nível de gerenciamento ou [...] em qualquer território político administrativo..." como um município, por exemplo (grifo nosso).
\end{abstract}

Com base nessas colocações, pode-se dizer que ao se planejar um determinado espaço de forma ordenada, o homem cria condições para manter um equilíbrio do sistema ao qual está inserido. Isso conseqüentemente reverterá em qualidade ambiental e de vida para toda a população (BOTELHO \& SILVA, 2004, p. 154).

\title{
2.2.1 - Zoneamento-Antrópico-Ambiental como proposta voltada à gestão do espaço geográfico do Município de Iporã do Oeste-SC
}

\footnotetext{
O zoneamento deve ser a conseqüência do planejamento. Um planejamento mal-estruturado, mal fundamentado poderá ensejar um zoneamento incorreto e inadequado (MACHADO, 1999, p. 126).
}

Um município quando da elaboração dos planos de desenvolvimento, deve levar em conta as legislações implementadas nas esferas superiores, ligadas ao Estado e a União. Quando se destaca a questão de políticas ambientais de recuperação e manutenção dos recursos naturais, se deve dar especial atenção à questão de zoneamentos em áreas agrícolas e urbanas.

De acordo com as colocações Cassol (1996), o termo zonear é um conceito geográfico, que significa dividir o espaço em zonas ou áreas com características 
específicas. Assim, o modelo de zoneamento depende, sobretudo, dos objetivos e da natureza dos indicadores e interações empregados no processo de análise espacial.

Smanio (1999, p. 92), destaca que o zoneamento: “...consiste em dividir o território em parcelas nas quais se autorizam determinadas atividades, ou se interditam o exercício de outras atividades...”. Desta forma, o zoneamento tem o papel de estabelecer as áreas prioritárias para determinados tipos de usos, considerando sempre o planejamento prévio, pensado e estruturado de forma eficiente.

Pode-se dizer ainda que o zoneamento, seja um instrumento técnico e político do planejamento, o qual visa implementar novos padrões de utilização do espaço geográfico, conservando este para as gerações futuras.

Nesta perspectiva, Rosa (1995, p.16), também destaca que, o objetivo principal de realizar um zoneamento em uma determinada área, num primeiro momento, é classificar e dividir o espaço com base em fatores ecológicos, econômicos e sociais, conduzindo posteriormente, ao cruzamento das informações, identificando assim, diferentes zonas ou áreas homogêneas, com seus problemas específicos, que serão objetos de proposta e de ordenamento do espaço geográfico. Num segundo momento, o objetivo do zoneamento tem em vista a organização adequada do espaço dentro de cada unidade homogênea estabelecida, com a indicação de áreas possíveis de serem utilizadas e as que serão destinadas à preservação, levando em consideração os princípios das leis ambientais e do Código Florestal na Lei no 4.771 de 1965, principalmente no que diz respeito ao seu Artigo $2^{0}$.

Assim, são várias as definições estabelecidas para se zonear uma determinada região, porém, o que se deve levar em conta é o objetivo principal de cada zoneamento e o conteúdo existente no mesmo. Por isso, tanto o Zoneamento Ambiental (ZA), o Zoneamento-Ecológico-Econômico (ZEE), quanto o ZoneamentoAntrópico-Ambiental (ZAA) são pensados e elaborados, visando atender determinados objetivos e necessidades, buscando conservar os recursos naturais e possibilitando uma melhor qualidade de vida para a população.

Alguns autores como Sanchéz e Silva (1995, p. 48), destacam que: 
A função principal do Zoneamento Ambiental é ordenar a diversidade de sistemas naturais, definindo a compartimentalização e comportamentos dessa diversidade, para que as diferentes ofertas da natureza deixem de ser estimadas como objetos imediatos de consumo e sejam valorizadas como expressões sensíveis de uma dinâmica, cuja compreensão condiciona a sustentabilidade do desenvolvimento.

Os mesmos autores ainda salientam que o ZA é uma ferramenta importante para projetar um território, uma vez que, é um documento estratégico que ordena a ocupação do espaço geográfico de forma "sistemática e prospectiva", buscando evitar o choque ou os conflitos entre os fatores ecológicos e sociais em função de apropriações do espaço de forma inadequada.

Considerando ainda as definições sobre as diferentes formas de zoneamento, pode-se dizer que o Zoneamento-Ecológico-Econômico (ZEE) é definido como um instrumento estratégico de planejamento municipal, regional e gestão territorial, tendo o intuito de contribuir para a implementação de ações que visem à prática de um desenvolvimento "sustentável"4.

Sendo assim, a elaboração ou a estruturação do ZEE envolve a realização de estudos sobre sistemas socioambientais, as potencialidades e as limitações que 0 espaço geográfico apresenta, envolvendo não somente os recursos naturais, mas principalmente as relações estabelecidas entre a sociedade e o meio ambiente. Em outras palavras, o ZEE deve abranger no seu conteúdo uma visão sistêmica e holística do espaço geográfico, a qual possibilite a análise de causa e efeito dos elementos físicos e humanos em suas relações de interdependência.

Por outro lado, fica claro que para se colocar em prática um zoneamento, deve-se respeitar a legislação vigente, desde as esferas superiores, adaptando-o para atender as necessidades e a realidade local. Neste sentido, o Decreto de $\mathrm{N}^{\circ}$ 4.297 de 10 de Julho de 2002, no seu Art. $3^{\circ}$, do Governo Federal, deixa claro que o ZEE deve:

... organizar, de forma vinculada, as decisões dos agentes públicos e privados quanto a planos, programas, projetos e atividades que, direta ou indiretamente, utilizem recursos naturais, assegurando a plena manutenção do capital e dos serviços ambientais dos ecossistemas.

\footnotetext{
${ }^{4}$ Del Prette (2007) http://www.abrasil.gov.br/avalppa/RelAvalPPA2002/content/av prog/186/prog186.htm Acesso
} em 15 de Agosto de 2007. 
Como parágrafo único do referido Decreto, tem-se o seguinte: "O ZEE, na distribuição espacial das atividades econômicas, levará em conta a importância ecológica, as limitações e as fragilidades dos ecossistemas, estabelecendo vedações, restrições e alternativas de exploração do território e determinando, quando for o caso, inclusive a relocalização de atividades incompatíveis com suas diretrizes gerais".

Nesse sentido, Moraes (2002, p. 24) complementa dizendo que, “...um zoneamento-ecológico-econômico deve ser visto como um plano de desenvolvimento regional e não como uma ação exclusiva do 'setor' ambiental da administração pública". Por isso, a participação da população também se faz importante nesse processo, pois estes são os agentes que estarão diretamente envolvidos na busca do desenvolvimento.

De modo geral, (WANDERLEY, 1998, p. 87) destaca também que: o "zoneamento-ecológico-econômico é a representação final do uso projetado para cada zona delimitada, onde constam os usos permitidos, os usos proibidos, as propostas de desenvolvimento, bem como as medidas essenciais para a viabilização para cada uma dessas zonas".

Em outras palavras, pode-se inferir que o ZEE, implica num reordenamento do espaço geográfico, bem como das atividades humanas sobre ele, possibilitando a criação ou até mesmo a ampliação de espaços ecologicamente equilibrados e economicamente viáveis, não perdendo de vista, obviamente, a sustentabilidade .

O Zoneamento-Antrópico-Ambiental é o resultado da análise integrada dos fatores físicos, econômicos, sociais e culturais, representado por meio de zonas homogêneas, envolvendo além dos recursos naturais, as perspectivas da sociedade em relação ao espaço geográfico ocupado.

Em outras palavras, acrescenta-se que o ZAA busca dividir o espaço geográfico em zonas homogêneas, a partir dos caracteres físicos, identificando as potencialidades e limitações existentes para posterior cruzamento com as informações econômicas e sociais, no intuito de organizar as áreas de forma ordenada, possibilitando o crescimento e o desenvolvimento econômico-social sem perder de vista a conservação dos recursos naturais.

Assim, o modelo de zoneamento que se propõem, constitui-se em um ordenamento do espaço geográfico a partir das microbacias hidrográficas 
delimitadas na área do Município de Iporã do Oeste-SC, baseado na identificação e caracterização dos fatores físicos, econômicos, sociais e culturais.

$\mathrm{Na}$ verdade, o ZAA, não apresenta significativas diferenças em relação ao ZEE. O ZAA, nesta concepção, visa estabelecer uma relação entre os fatores físicos e humanos, para a partir daí discutir e propor formas de uso e utilização do espaço geográfico adequadas as potencialidades físicas, econômicas e sociais existentes. Nesse contexto, serão levados em consideração, a partir do ZA, os projetos ou perspectivas da população com relação ao espaço ao qual se encontram inseridas. Por isso, um zoneamento quando bem elaborado passa a refletir a realidade do espaço geográfico, dentro das potencialidades e das restrições de uso.

Sendo para fins de planejamento estratégico e auxílio nas tomadas de decisões, o ZAA terá como resultado produtos cartográficos em escalas compatíveis com os objetivos de cada projeto. Dessa forma, ZAA elaborado tanto em escala macroregional, regional ou local deverá apresentar um conteúdo claro e objetivo, que atenda às necessidades de conservação dos recursos naturais e de desenvolvimento econômico e social.

Contudo, sabe-se que independente do tipo de zoneamento todos podem servir de instrumento estratégico para a tomada de decisões, ou seja, devem ser referência e instrumento para o planejamento e gestão dos recursos naturais, econômicos e ambientais, identificando as potencialidades e as limitações de cada região, orientando os projetos e os investimentos para que sejam elaborados de acordo com a vocação natural e econômica de cada espaço geográfico delimitado.

É importante reforçar também, que a participação da sociedade nas discussões a respeito do planejamento ordenação de determinadas áreas é de fundamental importância, uma vez que a mesma está diretamente inserida e envolvida no processo de ocupação e transformação desse espaço. Assim, o conhecimento a respeito da dinâmica local, permite pensar um espaço geográfico mais equilibrado e, sobretudo conservado, para que as gerações futuras possam usufruir.

A partir dessa reflexão, torna-se importante ressaltar que uma das formas de se planejar e elaborar um Zoneamento-Antrópico-Ambiental de um determinado território é por meio de estudos com as bacias ou microbacias hidrográficas. Concebida dentro da abordagem sistêmica como uma célula de análise, a microbacia reflete a realidade, a interdependência dos elementos que constituem o 
meio físico e o meio socioeconômico, permitindo que as informações sejam levantadas, analisadas e interpretadas de forma integrada (SPIRONELLO, 2002).

Sabe-se que inúmeras são as conceituações definidas pelos autores na área, e uma delas é extraída de Botelho (1999, p. 271), a qual aborda o conceito de bacia hidrográfica ou de microbacia como sendo: “...a área da superfície terrestre drenada por um rio principal e seus tributários, sendo limitada pelos divisores de água". A autora diz ainda que a bacia hidrográfica é uma célula natural e pode ser delimitada sobre uma base cartográfica que contenha cotas altimétricas, como por exemplo, as cartas topográficas.

Rocha (1997, p. 73), define a bacia hidrográfica como sendo: “... a área que drena as águas das chuvas por ravinas, canais e tributários para um curso principal, com vazão efluente convergindo para uma única saída". O autor destaca ainda que o conceito de microbacia é o mesmo que o de bacia hidrográfica, acrescido de que o deságüe se dá em outro rio, porém, com dimensões menores, podendo chegar até 20.000 ha.

Ainda com relação às dimensões estabelecidas das bacias e microbacias, Botelho \& Silva (2004, p.158), verificaram que através de trabalhos consultados, as bacias hidrográficas possuem dimensões que variam de entre 5 e $100.000 \mathrm{~km}^{2}$. Já as microbacias apresentam dimensões entre 20 e $50 \mathrm{~km}^{2}$. Dessa forma, os autores citados deixam claro que a microbacia é uma unidade básica para o planejamento ambiental.

O termo microbacia foi adotado para a referida pesquisa, por abranger a extensão territorial definida acima, e também por atender as características dos projetos desenvolvidos pela Epagri, órgão responsável pelo desenvolvimento de programas de planejamento agrícola no Estado de Santa Catarina, os quais adotam a mesma definição, face a realidade socioespacial existente nesse território.

Nesse preâmbulo, complementando as afirmações acima, pode-se dizer que as bacias ou microbacias hidrográficas podem ser entendidas como uma unidade natural onde os processos de relação e inter-relação se dão de forma dinâmica. Ela deve abranger uma área grande o bastante para identificar as relações e inter-relações que se estabelecem entre os elementos do meio físico e do meio social, para que os resultados de uma pesquisa, voltados principalmente ao planejamento ambiental e produtivo, sejam significativos (SPIRONELLO, 2002, p.14). 
Por outro lado, é importante destacar que “... os problemas gerenciais de uma bacia hidrográfica englobam uma multiplicidade de fatores [...] dentre eles podese destacar os sociais, econômicos e ambientais, e somente poderão ser adequadamente avaliados mediante uma abordagem sistêmica" (LANNA, 1995, p.53).

Hodiernamente, a população mundial está frente a uma realidade complexa e caótica no que diz respeito, principalmente, aos recursos hídricos. Pode-se afirmar com propriedade que essa realidade, crítica por sinal, é reflexo da falta de um planejamento adequado. O que era no princípio um recurso natural renovável poderá se tornar um recurso não renovável, finito, aqui algumas décadas se não forem tomadas medidas de recuperação e manejo.

Sabe-se, no entanto, que o Estado de Santa Catarina, em especial a região Oeste e Extremo Oeste, estão com os mananciais de água seriamente comprometidos em função, principalmente, do alto índice de contaminação dos recursos hídricos, por esgotos sanitários urbanos, desmatamento, exposição de nascentes, dejetos de suínos, entre outros, conforme destaca Botelho \& Silva (2004, p. 172). Os autores chamam a atenção sobre a grande quantidade de suínos, os quais ficam concentrados em pequenas áreas, elevando o acúmulo de dejetos. É destacado ainda que o poder poluente dos dejetos de suínos pode alcançar até 12 vezes mais em volume (litros) do que o esgoto produzido pelo homem.

Isso mostra uma realidade complexa, pois além do lençol subterrâneo estar contaminado, o solo é outro componente que fica altamente comprometido. Análises de água realizadas na região, revelam que mais de $80 \%$ das amostras apresentaram níveis de contaminação por coliformes fecais ${ }^{5}$. Logo, essa questão nos remete a outros infinitos problemas como o da saúde da população, pois a mesma, na maioria das vezes, acaba consumindo a água sem um tratamento adequado, principalmente no interior dos municípios da região Oeste e Extremo Oeste Catarinense.

Ante ao exposto há que se frisar que, nos últimos anos, tornou-se comum em épocas de estiagem a disputa pelos mananciais de água, o que vem comprometendo ainda mais esta questão, pois sabe-se que são várias as destinações de uso para esse recurso e uma delas é para à dessedentação de animais (suínos e aves).

\footnotetext{
${ }^{5}$ Informações obtidas junto ao Laboratório de Biologia da Universidade do Oeste de Santa Catarina Campus de São Miguel do Oeste-SC, na data de 20 de outubro de 2004.
} 
Por outro lado, em várias microbacias hidrográficas a escassez é um fato evidente. Spironello (2002), exemplifica o fato pela realidade apresentada pelo Rio Antas, o qual faz divisa com a área em estudo, o Município de Iporã do Oeste. Este rio apresenta uma situação preocupante, porém, só é mais crítica a realidade do Rio Macaco Branco, próximo ao Município de Tunápolis-SC, onde cerca de $70 \%$ da água disponível já seria utilizada.

Diante destas constatações fica clara a necessidade de:

...se planejar e gerenciar melhor os recursos naturais, entre eles os recursos hídricos, por isso, o manejo integrado de bacias hidrográficas é uma dessas formas. No entanto, o planejamento de bacias hidrográficas não deve ser pensado de forma isolada, as interações deverão ocorrer entre as demais microbacias vizinhas, o meio urbano, propriedades rurais etc., podendo alcançar diferentes escalas não só em nível municipal, regional, estadual, mas também nacional (SPIRONELLO, 2002, p. 15).

Nesse contexto, o Estado de Santa Catarina, desde 1991, vem desenvolvendo projetos de recuperação e manejo de microbacias. A necessidade de implantação desses projetos surgiu frente à grande problemática que o Estado vinha enfrentando, como: a degradação do solo, baixa produtividade nas lavouras e a altíssima contaminação dos recursos hídricos. Inicialmente, foi implantado o Projeto Microbacias I, em julho de 1991, o qual tinha como meta atender 520 microbacias ao longo de oito anos, findando em 1999 com 534 microbacias trabalhadas, conforme informações extraídas de Farah \& Barboza, (2000, p. 05).

Pensando em contribuir com a redução da degradação ambiental e a melhoria da qualidade ambiental e de vida da população localizada na zona rural, deu-se início ao Projeto Microbacias II, no ano de 2002. Este teve como meta atender 880 microbacias distribuídas em 293 municípios, priorizando alguns princípios básicos, como:

\footnotetext{
Assegurar aos agricultores mecanismos de apoio que promovam a melhoria da renda, da habitação, da qualidade do meio ambiente e sua sustentabilidade; priorizar os municípios com maior concentração de agricultores periféricos e em transição 1 e com maior grau de degradação ambiental; promover a capacitação dos diferentes atores envolvidos;
} 
implementar estratégias que permitam a participação dos beneficiários no processo de construção, execução e avaliação. ${ }^{5}$

Desta forma, o Município de Iporã do Oeste foi contemplado com cerca de $2 / 3$ das microbacias hidrográficas que se encontram inseridas na área de abrangência do município, isto é, das nove microbacias delimitadas, seis foram escolhidas dentro dos requisitos estabelecidos pelo projeto para serem trabalhadas. Assim, as microbacias hidrográficas delimitadas já estão em fase de implantação, de medidas preventivas de minimização de impactos ambientais, restando três microbacias para serem trabalhadas fora do Projeto Microbacias II. A escolha das seis microbacias hidrográficas se deu com base nas prioridades, ou seja, as que apresentaram maiores problemas de ordem ambiental, social e econômica.

Vale destacar que inúmeras são as vantagens da implantação deste tipo de projeto como: melhoria na qualidade e disponibilidade de água, na renda das famílias rurais, na habitabilidade rural, propriedades rurais reconvertidas, preservação da biodiversidade. Além disso, pode-se trabalhar visando o planejamento participativo, promovendo também a educação ambiental não só nas escolas entre alunos e professores, mas inclusive junto aos produtores rurais que estão ligados diretamente com 0 uso e ocupação desse espaço (JORNAL SCRURAL, 2002, p. 11).

Diante dessas colocações, fica evidente a importância de se planejar o espaço geográfico de forma racional, procurando juntamente com o poder público municipal, órgãos competentes e a comunidade, numa ação de parceria, apoiada nas leis ambientais, a busca de ações e/ou soluções viáveis, que sejam ambientalmente corretas no manejo e conservação dos recursos naturais.

\subsection{O GEOSSISTEMA COMO ABORDAGEM TEÓRICO-METODOLÓGICA NAS PESQUISAS DE PLANEJAMENTO SOCIOESPACIAL}

\footnotetext{
${ }^{5}$ Informações obtidas no site < http://www.fatma.sc.gov.br/projetos/convenio microbaciasll.htm > Acesso em 21/10/05.
} 
As pesquisas relacionadas às questões ambientais não são novidades no campo da Geografia, uma vez que o espaço geográfico sempre foi objeto de estudo para os geógrafos. É claro que inicialmente, as pesquisas eram envolvidas por um arcabouço teórico-metodológico diferente dos atuais.

Com base nisso, pode-se dizer que a Geografia desde o seu surgimento como ciência, passou por algumas mudanças conceituais e de paradigmas. Hoje, os pesquisadores procuram orientar suas pesquisas com base numa proposta teórica e metodológica, que atenda aos objetivos delineados.

A adoção de uma abordagem teórico-metodológica para orientar as reflexões sobre a pesquisa é de fundamental importância, uma vez que dá um caráter de cientificidade e seriedade aos trabalhos e pesquisas elaborados.

Uma das abordagens que surgiu com a Nova Geografia, na década de 60 do século passado, foi a Teoria Geral dos Sistemas. Apesar de a referida teoria ter sido introduzida em várias ciências, foi na Geografia, inclusive, que a visão sistêmica ganhou atenção especial. De acordo com Ribeiro de Melo (2004), havia uma preocupação em focalizar as questões geográficas sob a perspectiva sistêmica, e essa preocupação é que promoveu e possibilitou a dinamização e o desenvolvimento da Nova Geografia. A abordagem sistêmica também possibilitou a reformulação de conceitos, tornando as análises, principalmente de cunho ambiental, mais críticas.

Deve-se lembrar, no entanto, que esta visão de estudar o espaço geográfico de forma integrada, holística, vem desde a época de Alexandre Von Humboldt (1769/1859). Este, mesmo sendo naturalista, demonstrava a preocupação com as conexões existentes entre os elementos constituintes do espaço geográfico (TROPPMAIR, 2000).

Porém, foi no contexto histórico da Nova Geografia, que esta ciência passa a absorver o conteúdo dessa Teoria e adquirir uma nova cara diante da perspectiva de análise e discussão sobre a ocupação do espaço geográfico. Assim, nas suas discussões, todas as questões ligadas à natureza e à sociedade, entre elas, as questões ambientais passaram a receber "... uma abordagem fortemente carregada pela teoria dos sistemas, resultando em sua modelização e numerização" (MENDONÇA 1998, p. 30).

Com isso, os computadores ganharam espaço no auxílio às pesquisas e os trabalhos de campo foram substituídos pelos trabalhos em laboratório. Nesse 
sentido, dá-se maior importância aos procedimentos dedutivos do que aos indutivos, isto é, trabalha-se com um empirismo mais abstrato ao invés de se trabalhar com um empirismo concreto, palpável, perceptível (SPIRONELLO, 2002).

Com a evolução e ampliação da Teoria Geral dos Sistemas, vários autores foram formando conceitos e se configurando nesta abordagem dentro da Geografia Física, entre eles pode-se citar: Sotchava (1968, 1977), Bertrand (1971), Tricart (1977), Christofoletti (1999), Monteiro (2000) e Troppmair (2000). Tais autores trazem nas suas abordagens pontos em comum, bem como, contrapontos que fazem com que as discussões se ampliem.

O paradigma sistêmico na Geografia é de fundamental importância, pois participa ativamente das inter-relações que se estabelecem entre os elementos físicos e humanos, e procura se projetar numa dinâmica funcional e estrutural.

Portanto, pode-se dizer que, a conectividade é o princípio do estudo de sistemas. Ao se estudar um determinado espaço, a análise deve ocorrer entre todos os elementos constituintes do mesmo, caso contrário, não se avançará além dos limites da descrição. Por isso, a relação entre os fatos ou elementos é que vai estabelecer a concretude, uma vez que a realidade é uma soma de ligações complexas.

Dessa forma, o geossistema consegue estabelecer esta conexão, interagindo com seus elementos constituintes, numa dinâmica espaço-tempo. Essa dinâmica gerada pelo geossistema forma hierarquias em sua organização, podendo se estender desde a escala local até o global, isto é, dentro desta escala de abordagem pode-se partir de estudos com microbacias de algumas dezenas e centenas de hectares, até realizar estudos abrangendo o planeta.

Bertrand (1971), quando fala sobre o geossistema diz que este corresponde ao resultado da combinação de fatores geomorfológicos, climáticos e hidrológicos, bem como, de uma exploração biológica do espaço (solo, fauna e flora). Assim, o geossistema atinge seu clímax quando há um equilíbrio entre o potencial ecológico e a exploração biológica, consistindo em um complexo essencialmente dinâmico no tempo e no espaço. A estes dois fatores vem acrescida a ação antrópica.

Por apresentar uma dinâmica interna, o geossistema não possui uma homogeneidade fisionômica, e conforme reforça Bertrand (1971), a maior parte do tempo o geossistema é formado por paisagens diferentes, as quais representam 
diversos estágios de evolução dentro de um geossistema (SPIRONELLO, 2002, p. 07-08).

Nessa perspectiva, a Figura 01 mostra o esboço metodológico da definição do geossistema, elaborado pelo autor.

Clima-Hidrografia-Geomorfologia

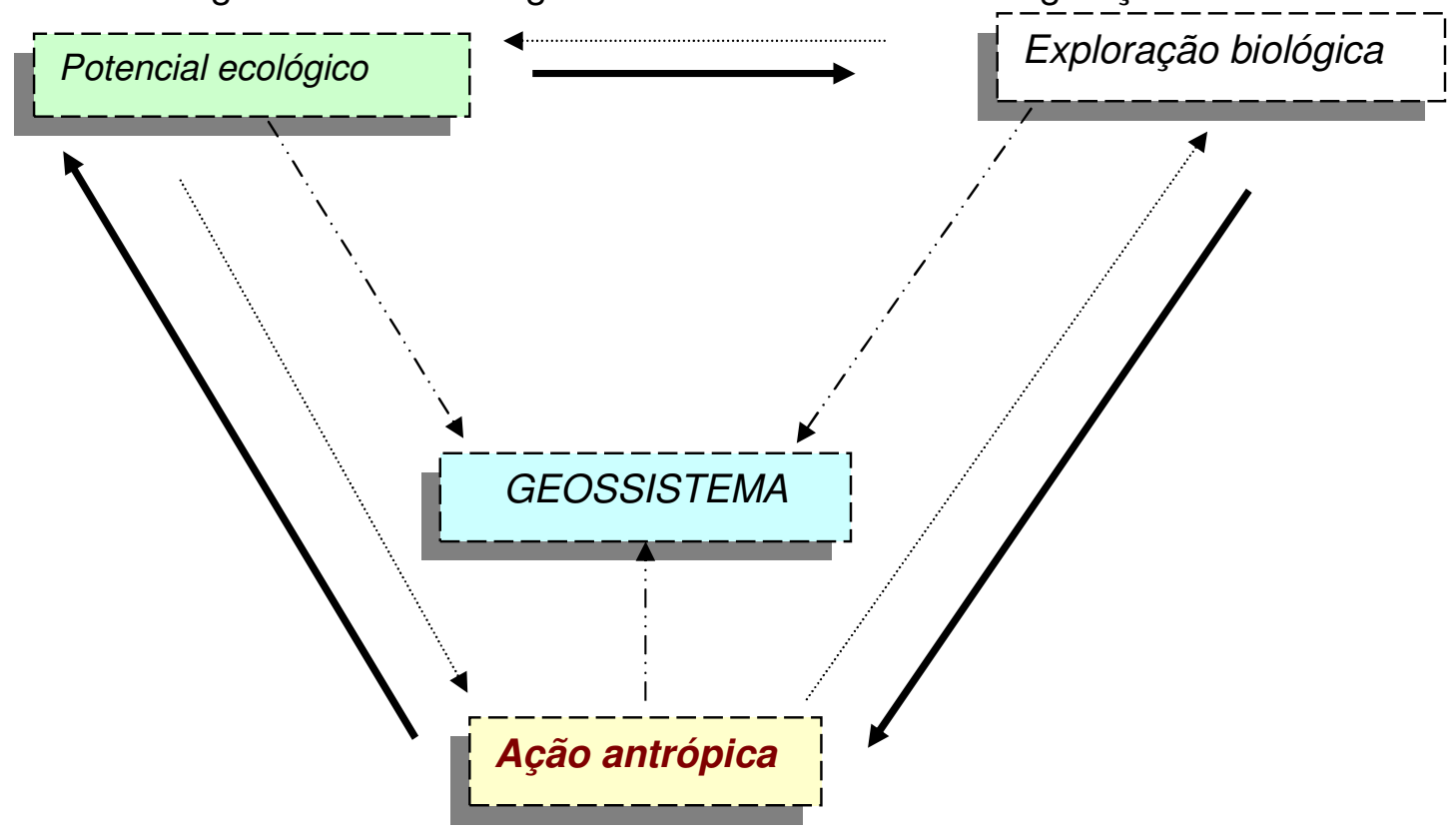

Figura 01 - Esquema de relações estabelecidas entre os elementos de um Geossistema proposto por Bertrand (1971).

Sotchava (1977, p. 9), introduz o conceito de geossistema dizendo que: "Geossistemas são uma classe peculiar de sistemas dinâmicos abertos e hierarquicamente organizados". Em suas considerações, o autor diz que o elemento básico para a classificação do geossistema é o espaço e que a escala de análise pode variar do global até o local.

Sotchava recebe algumas críticas dos colegas pesquisadores, por ressaltar que o geossistema, na sua concepção, é entendido como um fenômeno natural e que a dinâmica estabelecida por esta abordagem é o resultado das conexões que se estabelecem no seu interior.

Apesar de a abordagem geossistêmica dentro da Geografia também ter sofrido críticas de alguns pesquisadores no decorrer das últimas décadas, sua 
distribuição tem sido significativa para a Geografia Física, principalmente para pesquisas voltadas às análises ambientais e ao planejamento (MONTEIRO, 2000).

Com base nisso, Troppmair (2000, p. 38) acrescenta dizendo que:

...o estudo dos geossistemas conquistou importância e aplicação crescente, buscando entre outros objetivos, a conservação, o uso racional dos recursos naturais e o desenvolvimento do espaço geográfico, beneficiando, com isso, toda a biosfera, em especial a sociedade humana.

Dessa forma, o uso da abordagem teórico-metodológica - geossistema abre um leque significativo quando se pensa na utilização prática de seus resultados. O mesmo permite realizar estudos e levantar problematizações numa perspectiva de inter-relação entre o homem e a natureza.

Decorrente disso, o geossistema dentro da Geografia permite também que por meio de sua abordagem se possa trabalhar numa escala espaço-temporal, tendo a Cartografia como ciência interligada na elaboração dos produtos cartográficos, analisando e projetando alternativas de otimização dos problemas levantados.

Deste modo, entendendo-se que o meio físico é um sistema que resulta da interação entre os fatores físicos, socioeconômicos e culturais, destaca-se que a abordagem sistêmica é a metodologia que responde aos objetivos da referida pesquisa. A interação e a interdependência entre os elementos acima citados, conduzem com clareza a capacidade de observação e de explicação dos processos da dinâmica socioespacial que se estabelece no geossistema num determinado espaço geográfico. 


\section{3 - CARACTERIZAÇÃo GERAL DA ÁREA DE ESTUDO}

\section{1 - FATORES FÍSICOS, SOCIAIS E ECONÔMICOS DA ÁREA DE ESTUDO}

A área de estudo, o Município de Iporã do Oeste - SC, localiza-se a aproximadamente $780 \mathrm{~km}$ de Florianópolis, $30 \mathrm{~km}$ da divisa com a Argentina e cerca de $30 \mathrm{~km}$ da divisa com o Rio Grande do Sul. Localizado entre as coordenadas $27^{\circ}$ 37' 54" Latitude Sul e 520 16' 52" Longitude Oeste, Iporã do Oeste integra a Microrregião da $\mathrm{AMEOSC}^{6}$, a qual abrange um total de 19 municípios.

O Município de Iporã do Oeste está localizado na zona agroecológica 2C, conforme estudos realizados pela Epagri (1999, p. 178), o clima é classificado como "...mesotérmico brando". Conforme o autor citado, "...a temperatura média anual varia de $17,9^{\circ} \mathrm{C}$ a $19,8^{\circ} \mathrm{C}$ ". As médias máximas de temperatura situam-se em torno de $26,3^{\circ} \mathrm{C}$, e as médias mínimas térmicas predominam entre $12,9^{\circ} \mathrm{C}$ a $14,0{ }^{\circ} \mathrm{C}$. A precipitação média anual na zona agroecológica $2 \mathrm{C}$ é de 1.430 a $2.020 \mathrm{~mm}$. A umidade relativa do ar está entre $77 \%$ a $82 \%$.

De acordo com as informações extraídas da Epagri (1999, p. 178), "Pode ocorrer, em termos normais, de 5 a 12 geadas por ano". A insolação varia de 2.117 a 2.395 horas. Sabe-se, no entanto, que estes dados estão sofrendo alterações de forma constante no decorrer dos anos, em função principalmente das alterações climáticas globais (que se mostra através do fenômeno El Nino e La Ninã), os quais, juntamente com as mudanças do microclima regional provocam, em determinadas épocas do ano, mais especificamente nos meses de dezembro a fevereiro, períodos de estiagem, causando transtornos a toda a população. Diminuindo o regime de chuvas nessa época, altera consideravelmente o fluxo de água dos rios, açudes e poços, os quais são a principal fonte hídrica para o abastecimento da população e dessedentação de animais (aves, suínos e bovinos).

No que tange aos aspectos geológicos, Epagri (1999) destaca que o Município de Iporã do Oeste, o qual faz parte da zona agroecológica 2C, encontra-se inserido dentro da Formação Serra Geral, pertencente ao grupo geológico São Bento. Vale lembrar, no entanto, que: “...a área recoberta por este evento vulcânico

\footnotetext{
${ }^{6}$ Associação dos Municípios do Extremo Oeste de Santa Catarina.
} 
abrange 52\% do Estado de Santa Catarina" (Epagri, 1999, p. 180). As rochas são oriundas de eventos vulcânicos, e conforme expressa o Instituto de Planejamento e Economia Agrícola, (1990), a região é constituída de rochas eruptivas básicas, intermediárias e ácidas, conjunto ígneo denominado Serra Geral. A Figura 02 mostra o conjunto de rochas basálticas, estrutura geológica predominante na área de estudo.

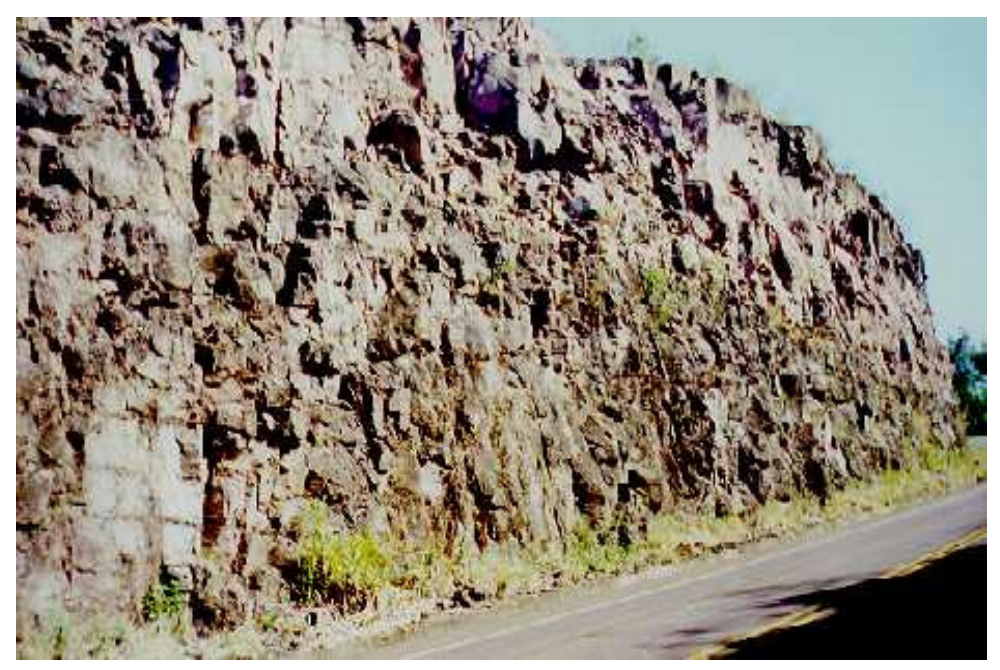

Figura 02 - Conjunto de rochas basálticas, constituição geológica predominante da área de estudo. Corte no estrato, - proximidades da comunidade de Taipa Alta.

Organização: Rosangela L. Spironello, Jan/2005.

No que se refere aos aspectos litológicos, na região do Extremo Oeste Catarinense há o predomínio do basalto, assim, os solos que compõe a área do Município de Iporã do Oeste são derivados de rochas efusivas básicas e ácidas, conforme já destacado acima. Desta forma, os solos apresentam a seguinte classificação, de acordo com (PUNDEK \& MOLINARI, 2001). Cambissolos, Gleissolos, Latossolos, Neossolos e Nitossolos.

Cambissolos - "São solos constituídos por material mineral com horizonte B, incipiente imediatamente abaixo do horizonte $A$ ou horizonte hístico com espessura inferior a $40 \mathrm{~cm}$;

Gleissolos - "Solos constituídos por material mineral com horizonte glei imediatamente abaixo do horizonte A, com menos de $40 \mathrm{~cm}$ de espessura; ou horizonte glei começando dentro de $50 \mathrm{~cm}$ da superfície do solo; ou ainda horizonte glei começando a profundidade entre 50 e $125 \mathrm{~cm}$ desde que imediatamente abaixo 
de horizonte A ou $E$ (gleizados ou não). Não apresenta horizonte B textural com mudança textural abrupta coincidente com o horizonte glei";

Latossolos - "Solos constituídos por material mineral, apresentando horizonte $B$ latossólico imediatamente abaixo de qualquer tipo de horizonte $A$, dentro de $200 \mathrm{~cm}$ da superfície do solo ou dentro de $300 \mathrm{~cm}$, se o horizonte A apresenta mais de $150 \mathrm{~cm}$ de espessura";

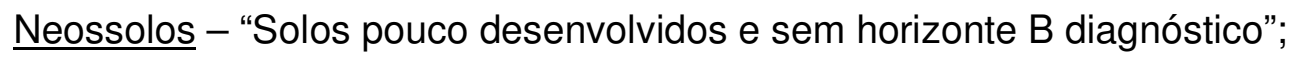

Nitossolos - "Solos constituídos por material mineral que apresentam horizonte $\mathrm{B}$ nítico, com argila de atividade baixa imediatamente abaixo do horizonte A, ou dentro dos primeiros $50 \mathrm{~cm}$ do horizonte B".

Conforme destaca o (INSTITUTO DE PLANEJAMENTO E ECONOMIA AGRíCOLA, 1990). Os aspectos geomorfológicos desta região englobam duas unidades, a saber: O Planalto Dissecado Rio Iguaçu/Rio Uruguai e Planalto dos Campos Gerais, os quais pertencem ao domínio morfoestrutural das Bacias e Coberturas Sedimentares.

Nesse sentido, o Planalto Dissecado do Rio Iguaçu/Rio Uruguai, no qual se encontra inserida a área de estudo, ocupa uma área significativa, com altitudes que variam de 1000 metros na porção leste e 300 metros na porção oeste no limite internacional com a Argentina. De modo geral, o relevo da região apresenta acentuadas dissecações, ou seja, elevadas altitudes e vales profundos, com vertentes escalonadas formando patamares (INSTITUTO DE PLANEJAMENTO E ECONOMIA AGRÍCOLA, 1990). Da mesma forma Epagri (1999, p.179), complementa dizendo que: "A forma de relevo é dada por um interflúvio estreito de topo plano ou levemente convexizado, interrompido por uma vertente de forte declividade, como escarpa, apresentando degraus que configuram patamares".

No que se refere à hidrografia, os principais cursos d'água que drenam a região do Extremo Oeste catarinense são: o Rio Uruguai, Rio Peperi-Guaçu e o Rio Antas. O Rio Uruguai faz divisa entre o Estado de Santa Catarina e Estado do Rio Grande do Sul e encontra-se localizado a uma distância aproximada de $30 \mathrm{~km}$ do Município de Iporã do Oeste. Historicamente, esse rio teve uma participação decisiva no processo de ocupação da região, pois serviu de portão principal para a passagem dos colonos oriundos do Estado do Rio Grande do Sul, no início do século passado, e também de meio de transporte para a exportação de madeira para o país vizinho, a Argentina. 
Apesar de apresentar em sua configuração um percurso sinuoso em função das características topográficas da região, é um dos únicos rios que em alguns trechos possibilita a navegação. O Rio Peperi-Guaçu, o qual faz divisa entre o Brasil e a Argentina, tem sua nascente no Município de Dionísio Cerqueira-SC, desaguando assim, no Rio Uruguai. Este, não oferece condições de navegação em seu leito, face a irregularidade e a sinuosidade do seu curso (SPIRONELLO, 2002). Pode-se dizer também que, em épocas de estiagem, o Pereri-Guaçu é um importante fornecedor de água para o abastecimento de aviários e chiqueirões em toda a região do extremo oeste catarinense.

O Rio Antas, em termos de volume e vazão de água é menor que os rios acima citados, não apresentando uma importância comercial - de locomoção significativa, porém, apresenta um potencial ambiental relativamente grande, com espécies diversificadas de peixes que vão se juntar com as demais espécies que povoam o curso d'água do Rio Uruguai.

De modo geral, a hidrografia na região apresenta características semelhantes nos seus cursos, com a presença de corredeiras, pequenas cachoeiras, dado que, a unidade geomorfológica constitui-se de um relevo dissecado com vales profundos. Quanto ao padrão de drenagem, os rios localizados em toda a região do Extremo Oeste Catarinense, podem ser classificados como de padrão dendrítico. Christofoletti (1974, p. 82), define o padrão como dendrítico porque: "...em seu desenvolvimento assemelha-se à configuração de uma árvore", isto é, o curso principal corresponde ao tronco de uma árvore, e seus afluentes, aos galhos, que se distribuem por todas as direções sobre a superfície do terreno, formando ângulos agudos com graduação variada.

Em Iporã do Oeste, os Rios, Lajeados e Arroios que drenam o município não apresentam importância considerável no contexto regional, pois os cursos d'água são de pequeno porte. Os principais rios são: O Rio Antas já mencionado acima, Lajeados Vorá, Jundiá e Pirapó. O Rio Antas localiza-se na porção leste do município, fazendo divisa com o município de Riqueza. O Lajeado Vorá, afluente do Rio Antas, faz divisa com o Município de Descanso, na porção norte. O Lajeado Pirapó, afluente do Rio Macaco Branco, contorna suas águas na porção norte do município e faz divisa com o Município de Descanso e Santa Helena. Este Lajeado, por sua vez, é o que fornece a água para a população urbana do município. Já os Lajeados Jundiá e das Letras fazem divisa com o Município de Tunápolis. 
A vegetação que cobre o espaço geográfico do Oeste Catarinense era composta, inicialmente, pelas seguintes regiões fitoecológicas: "a Região de Savanas (Campos do Planalto) com diversas formações campestres, situadas em regiões de relevo mais suave; Floresta Ombrófila Mista (Floresta de Araucárias) com domínio em relevo que varia de 500 a 600 metros de altitude; Floresta Estacional Decidual (Floresta Caducifólia) a qual penetra-se na bacia do Uruguai em relevo abaixo dos 500/600 metros de altitude" (Atlas Geográfico de Santa Catarina, 1989).

Nesse contexto, a FUNDAÇÃO DE AMPARO À TECNOLOGIA E MEIO AMBIENTE - Fatma (1978) destaca que, inicialmente a vegetação que cobria o extremo oeste catarinense, no qual se encontra inserido o Município de Iporã do Oeste, era composta de dois principais tipos florestais: a Floresta Subtropical da Bacia do Uruguai com a presença da Grápia (Apuleia leiocarpa), Guajuvira (Patagonula americana), Angico (Parapiptadenia rígida), Cedro (Cedrela fissilis), Louro (Cordia trichotoma), e Canelas (Ocotea spp.e Nectranda spp); e a Floresta de Araucária do Extremo-Oeste, com submata onde tinha-se a predominância do Angico (Parapiptadenia rígida), da Grápia (Apuléia leiocarpa), da Guajuvira (Patagonula americana) e das Canelas (Nectandra ssp)". Nos dias atuais, tais espécies encontram-se em extinção no local, ou com a presença de algumas poucas remanescentes, conseqüência do processo de colonização empreendido na região no início do século passado. AB' SABER (2003), situa esta região na classificação paisagística dos domínios de natureza do Brasil, como o domínio dos Planaltos de Araucárias.

Nesse contexto, Spironello $(2001,2002)$ realizou estudos sobre o Município de Iporã do Oeste e constatou que a cobertura florestal existente é de aproximadamente $5.625,43$ ha, ou $28,1 \%$ da área total do município. Nesta classificação estão incluídas, a mata nativa, a exóticas, a capoeira e os capoeirões. Embora o município apresente uma porcentagem considerada de florestas, acredita-se que a região possa apresentar a mesma realidade, uma vez que, tem-se assistido certo abandono de algumas propriedades, por parte de famílias de agricultores descapitalizados. Essa condição de total descapitalização do campo faz com que tal espaço seja esquecido, e assim, sem a atuação do homem, a natureza de forma graciosa dá conta de buscar a sua recomposição. 


\section{2 - CONSIDERAÇÕES À RESPEITO DO PROCESSO DE OCUPAÇÃO DO ESPAÇO CATARINENSE}

Conhecer o processo de ocupação do espaço, geográfico ao qual a sociedade encontra-se inserida, é de fundamental importância para entender a atual organização socioespacial, abrangendo desde os seus fatores políticos, econômicos, sociais e ambientais.

No que diz respeito ao processo de colonização do Estado de Santa Catarina, este envolveu três grandes regiões em épocas distintas: o litoral; o planalto e o oeste (meio e extremo oeste).

Conforme Espírito Santo (1999, p. 45): “...a ocupação do litoral iniciou-se com a chegada dos vicentistas, no século XVII. Oriundos de São Vicente e Piratininga, São Paulo, estes se instalaram na llha de São Francisco, em Desterro (Florianópolis), bem como em Laguna". Representavam as bases para a conquista portuguesa no Sul. Para organizar sua produção, que era de subsistência, essa população procurava solos agrícolas de baixada, onde, produziam farinha de mandioca, algodão, cana-de-açúcar, peixe seco, entre outros.

Os açorianos foram o segundo grupo a chegar ao Estado, por volta do século XVIII. Estes ocuparam Desterro e o Continente. A população era constituída basicamente de pequenos agricultores e pescadores. A atividade da pesca tinha uma importância significativa para os açorianos, uma vez que era a base de sua economia. De acordo com a autora acima citada, tanto os vicentistas quanto os açorianos enfrentaram as mesmas dificuldades em busca do desenvolvimento. $O$ atraso científico cultural dificultava ou até mesmo impedia a implementação de atividades ligadas a manufatura, sem falar das próprias dificuldades impostas pela metrópole.

No século XIX, tem-se a penetração dos colonizadores europeus, incentivados pelo governo imperial, com o objetivo de preencher um vazio populacional. Nessa época, os alemães, italianos e poloneses foram as principais etnias que se instalaram no litoral e regiões adjacentes. Com isso, várias cidades foram fundadas, como: Joinville, Blumenau, Brusque, Nova Trento, Criciúma, Itajaí, entre outras. Algumas colônias, em especial as alemães nessa época, receberam ajuda financeira de organizações privadas, contribuindo assim para 0 avanço econômico e social da região. 
A segunda região a ser povoada foi o planalto catarinense, por volta de 1720. Inicialmente, esta região servia apenas de rota para o transporte do gado gaúcho que era conduzido ao Centro-Oeste e Sudeste do país para ser comercializado. Essa rota ficou conhecida de acordo com (INSTITUTO DE PLANEJAMENTO E ECONOMIA AGRÍCOLA, 1990) como "Caminhos do Sul". Ainda conforme o autor citado, ao longo deste caminho, vários povoados foram surgindo, dando origem a várias cidades, dentre elas: Lages, Curitibanos e Campos Novos.

Mais tarde, outras frentes se instalaram na região, todas com o objetivo de se dedicarem ao pastoreio, dando origem a uma estrutura fundiária baseada no latifúndio. O coronelismo se destacava, o dono da fazenda era quem detinha o poder sobre qualquer tomada de decisão.

Baseado no latifúndio e com os sistemas de posses dos caboclos (etnia que já habitava a região antes da vinda dos tropeiros e colonizadores de descendência européia), o planalto catarinense norteou o seu desenvolvimento até o início do século XX. As atividades econômicas que predominavam eram as criações de gado, a extração de erva-mate e da madeira (INSTITUTO DE PLANEJAMENTO E ECONOMIA AGRÍCOLA, 1990).

Conforme destaca o autor, para facilitar o escoamento dos produtos de erva-mate e madeira do Estado do Rio Grande do Sul, Santa Catarina e Paraná, ao mercado consumidor da região Sudeste do Brasil, principalmente, em 1893, foi autorizada a construção da estrada de ferro São Paulo-Rio Grande.

Foi, porém, a partir da construção da estrada de ferro, no período entre 1907 a 1910, que o processo colonizador ocorreu, o qual significou o marco da colonização no oeste catarinense. Piazza (1983), em suas colocações nos diz que, a empresa responsável pela construção da estrada de ferro no trecho que abrangia a área de Santa Catarina foi a Brazil Railway, tendo como subsidiária a Brazil Development \& Colonization, a qual recebeu do Governo Federal como pagamento em forma de concessão, quinze quilômetros de terras em cada lado da ferrovia. Essa concessão conforme destaca Silva (1987, p. 14), “...foi atribuída a título de indenização pelas despesas feitas com a construção da Rede Ferroviária para colonizar dentro de 50 anos, que espirou mais ou menos pelos anos de quarenta e poucos...".

Assim, essa concessão foi permitida, sendo apropriada pela empresa sem levar em consideração alguma posse anterior ou títulos legais já existentes, ou seja, 
desconsiderou que ali viviam pessoas (caboclos) que tinham um vínculo harmônico com a natureza.

Em função da construção da estrada de ferro, um contingente significativo de pessoas foi trazido para trabalhar, favorecendo a mistura entre as raças (índios, caboclos e brancos). A heterogeneidade social, resultante do processo de ocupação das terras nesta região, vai refletir num grande conflito conhecido como a Guerra do Contestado. Esta guerra acabou por eliminar grande parte dos posseiros e caboclos, favorecendo o avanço das empresas colonizadoras a partir de 1917.

Finalizada a questão do Contestado, por volta de 1917, o governo do Estado de Santa Catarina tratou de criar condições necessárias para que a região do meio e extremo oeste fosse colonizada. Os primeiros municípios a serem implantados foram: Chapecó e Cruzeiro (Joaçaba) em 1917. Com a instalação de novos municípios e comarcas judiciárias, a conquista dessa região passou a se fundamentar, estendendo-se até a década de 60 do século passado. Nesta região, a principal atividade desenvolvida pelos colonizadores, inicialmente, era a criação de porco tipo banha e além de se dedicarem às culturas de subsistência, com a produção de milho, batata e feijão.

Com relação ao Extremo Oeste de Santa Catarina, as áreas inicialmente povoadas foram às margens do Rio Uruguai, com posterior interiorização, dando origem a vários povoados como; Mondaí e de Pinhal, denominado hoje de Iporã do Oeste.

\section{3 - PROCESSO DE FORMAÇÃO TERRITORIAL E CARACTERIZAÇÃO SOCIOECONÔMICA DO MUNICÍPIO DE IPORÃ DO OESTE-SC}

O processo histórico da formação do Município de Iporã do Oeste, inicia-se em 1919 com a colonização às margens do Rio Uruguai, termo este, originário do Guarani que significa "água dos caracóis" ou búzios (Uruguá = caracol e $Y=$ água), (JUNGBLUT apud SPIRONELLO, 2002).

De acordo com dados levantados por Piazza (1983), os primeiros colonizadores vieram das localidades de Panambi, Nonoai e Sarandi-RS. Os imigrantes descendentes destas localidades criaram a Empresa Colonizadora 
"Chapecó-Pepery", a qual passou a vender aos colonos lotes coloniais de 24,4 hectares ao valor de $3.000 \$ 000$ na época.

No ano de 1921 foi fundado o povoado de Porto Feliz, o qual denomina-se hoje Mondaí-SC. Os colonos que se instalaram nesta localidade, eram na sua maioria, de origem alemã, preferencialmente evangélica.

Iporã do Oeste, que na época da colonização pertencia ao povoado de Porto Feliz, foi colonizado inicialmente por alemães e italianos e em menor proporção por russo-ucranianos (SECRETARIA DE EDUCAÇÃO, CULTURA, DESPORTO E TURISMO, 1998).

As primeiras famílias chegaram por volta de 1925-1926 a Pinhal (hoje Iporã do Oeste), nome este, atribuído em função de extensas áreas cobertas por pinheiros - Araucária -. Os pioneiros que merecem destaque são: Balduino Wandcher, Ervino Luiz Klaesner, Eduardo Gustavo Fetter, Reinoldo Wandscheer e Walter Horst (SECRETARIA DE EDUCAÇÃO, CULTURA, DESPORTO E TURISMO, 1998).

Essas famílias, no princípio enfrentaram muitas dificuldades para conseguir os gêneros alimentícios. A aquisição era feita em Porto Feliz - Mondaí - , onde os colonos se deslocavam a cavalo por meio de pequenas aberturas na mata "picadas" -, regressando somente três dias após, contando, porém, com a dificuldade da não aquisição de certos produtos, por serem escassos. Ocorria às vezes que, muitos dos colonos comiam feijão pela parte da manhã, tarde e noite por não ter farinha. (SECRETARIA DE EDUCAÇÃO, CULTURA, DESPORTO E TURISMO, 1998).

Por outro lado, a caça era abundante naquela época, caçavam-se: antas, porcos-do-mato, veados e cotias. O porco tipo comum era criado com certa facilidade, porém, a dificuldade maior era vender.

Motivados pelo fator econômico, os colonizadores buscaram na extração da madeira de lei e na agropecuária o desenvolvimento de sua economia. A existência da mata nativa exuberante e a fertilidade do solo proporcionaram aos imigrantes calçar suas bases de produção, podendo competir até com o mercado externo, principalmente com a Argentina.

No decorrer do tempo, o setor da agricultura também ganhava destaque, onde vários produtos eram cultivados, mas a batata inglesa era o produto que tinha uma comercialização relativamente fácil, sendo vendida para os tropeiros que se 
dirigiam a Barracão-PR (SECRETARIA DE EDUCAÇÃO, CULTURA, DESPORTO E TURISMO, 1998).

Em 1929, o presidente do Estado de Santa Catarina, o Senhor Adolfo Konder, visitou a região, inclusive a localidade de Porto Feliz, e na oportunidade autorizou o início da construção da estrada de acesso a Porto Feliz - Dionísio Cerqueira-SC.

Ainda no ano de 1929, foi construída a primeira serraria que se localizava onde hoje pertence o lote de Roque A. Colling. Seus proprietários eram Cristiano Wandscher e Armindo Stangler. Inicialmente, serravam-se somente os pinheiros (Araucaria angustifolia), por ser uma espécie que havia em abundância. Cortavamse as pranchas da madeira e somente as de primeira qualidade eram exportadas. Toda madeira tinha o escoadouro pelo Rio Uruguai, partindo de Mondai até São Borja, no Rio Grande do Sul, com destino à Argentina (SECRETARIA DE EDUCAÇÃO, CULTURA, DESPORTO E TURISMO, 1998). Posteriormente, com a extinção da Araucária no município e na região, outras espécies nativas como o Cedro (Cedrela fissilis) e o Louro (Cordia trichotoma) eram serrados para a comercialização. (SPIRONELLO, 2002, p. 49).

Nesse contexto, outras serrarias vieram a se instalar em função da exuberância das matas. A Figura 03 (a) e (b) mostra algumas espécies de toras de pinheiro e angico já serradas para a fabricação de pranchas para a comercialização. Ao fundo das figuras, pode-se observar a predominância de araucárias - pinheiros espécies praticamente extintas nos dias atuais.

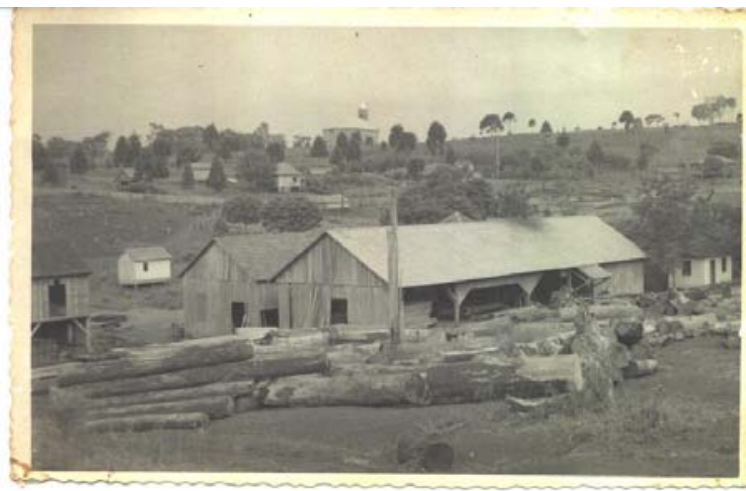

Figuras - 03 (a) - Vista da Serraria de Reinoldo Organização: Rosangela L. Spironello, Jan/2005.

Fonte: Secretaria Municipal da Educação do Município de Iporã do Oeste. de madeira.

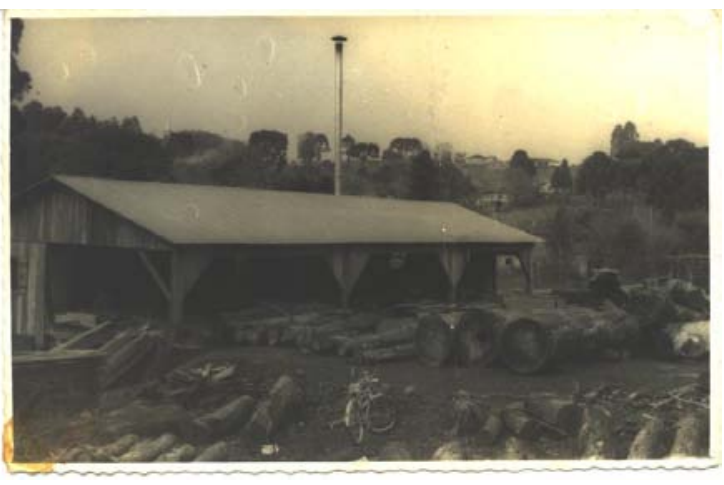

(b) Serraria de Ruschel \& Cia 
Várias foram ás dificuldades encontradas pelos colonizadores para proporcionar melhores condições de vida à população. O esforço com que se dedicavam às atividades e aos novos empreendimentos eram compensados com conquistas, como: moinho colonial, primeira casa colonial, as primeiras salas de aula, sendo ministradas aulas em Língua Alemã pelo senhor Karl Ebenau. Essa casa, por sua vez, era mantida pelo consulado alemão, com sede em Mondaí (SPIRONELLO, 2002, p. 49-50).

De acordo com a autora citada, no ano de 1934 foi construída a primeira escola com o nome de Escola Mista Territorial Pinhal, a qual foi assumida pelo governo do Estado de Santa Catarina, que na época, era coordenada pela Inspetoria de Itapiranga-SC. Posteriormente, em 1961, o prédio foi ampliado com mais salas de aula para atender a demanda da comunidade escolar.

Na década de 40 (séc. XX), Pinhal recebe o seu primeiro caminhão, o qual pertenceu à empresa de Paulo Koch de Carazinho-RS. Tal empresa fazia negócios com Frederico Kreiser.

Na trajetória histórica de Pinhal, novas conquistas se fizeram presentes década de 50-60, entre elas a instalação do primeiro aparelho telefônico à manivela, que através de um fio mantinha contato com Mondaí.

Conforme dados levantados por Piazza (c1994, p. 314-315), Pinhal tornouse distrito de Mondaí - com a denominação de Iporã, nome este derivado do dialeto indígena Guarani que significa "Água Boa" - , em 13 de novembro de 1956, aprovada pela Lei estadual número 267. Assim, foi nomeado o primeiro sub-prefeito o Sr. Walter Horst.

Vale destacar que no ano de 1960, de acordo com o recenseamento, a população localizada na sede distrital era de 434 habitantes, destes, 235 homens e 199 mulheres. Já em 1970, ainda como distrito de Mondaí, Iporã contava com um total de 6.283 habitantes, dos quais 3.334 homens e 2.929 mulheres.

Um fato interessante que marcou a trajetória histórica de Iporã foi a criação da primeira feira agropecuária industrial e comercial, na Linha Faic, a qual realizouse nas datas de 21 a 25 de julho de 1972. Conforme o regulamento da $1^{\text {a }}$ FAIC, no seu Capítulo I, Art. $3^{\circ}$, essa feira tinha como objetivos:

a) - Proporcionar aos pecuaristas e agricultores a oportunidade de visualização ampla do estágio tecnológico que atingimos, bem como o 
confronto dos métodos de trabalho e aferição de seus rendimentos através do exame dos espécimes expostos;

b) - Demonstrar a quem possa interessar o conhecimento atualizado da economia rural catarinense, as realizações e possibilidades deste estado, promovendo intercâmbio econômico interno e com as demais Unidades da federação;

c) - Atrair capitais de investimentos nessas atividades agropecuárias, bem como para a implantação de novas indústrias, incentivando, ainda, a ampliação das já existentes;

d) - Incentivar o intercâmbio das classes rurais, provando de que pela cooperação e boa vontade é possível ao homem rural desempenhar o papel que a ele está reservado;

e) - Fomentar o melhoramento da produção, através de prêmios, troféus [...]. Regulamento da $1^{\text {a }}$ FAIC, 1972, folha 1.

Esse evento contou com a participação de expositores de bovinos, suínos, aves, coelhos, agricultura, indústria e comércio. Pelos objetivos acima descritos, constados no regulamento da $1^{\mathrm{a}}$ feira, pode-se perceber que, ao menos no papel, havia uma preocupação em promover o desenvolvimento local tanto dos agricultores, como dos comerciantes do distrito, na época. A feira agropecuária industrial e comercial infelizmente não teve continuidade nos anos seguintes, por falta de incentivo e perseverança das pessoas envolvidas com os setores de desenvolvimento.

Para a época, pode-se dizer que esse evento era considerado como um dos maiores eventos de abrangência regional e estadual. A Figura 04 mostra a vista parcial do parque de exposições.

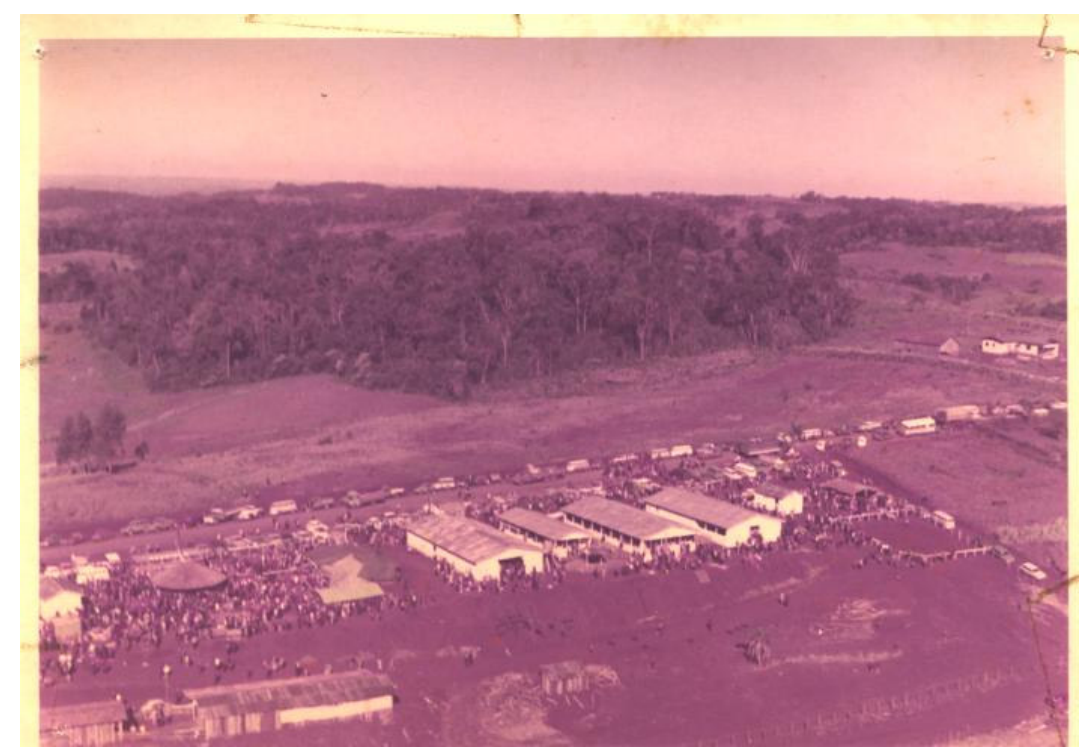

Figura 04 - Vista parcial do parque de exposições da Linha FAIC, Iporã no ano de 1972. Organização: Rosangela L. Spironello, Jan/2005.

Fonte: Secretaria Municipal da Educação do Município de Iporã do Oeste. 
No ano de 1980 foi instalada a Paróquia Nossa Senhora da Mercês, contando na época com dezessete comunidades já formadas, surgindo anos mais tarde seis novas comunidades. O primeiro Padre foi Luiz Heinen.

No ano de 1984, com a organização e a conscientização popular, a autonomia político-administrativa começou a ser conquistada. Esta autonomia somente é conquistada, em 04 de Janeiro de 1988, pela Lei № 1.098, com a emancipação do município. Nesse mesmo ano, o nome de Iporã foi alterado por meio de um plebiscito, optando-se por Iporã do Oeste. No dia 01 de Junho de 1989, Severino Seger toma posse como o primeiro prefeito eleito do município, (SECRETARIA DE EDUCAÇÃO, CULTURA, DESPORTO E TURISMO, 1998).

Com a emancipação, o Município de Iporã do Oeste passa a se desenvolver sobre uma base sólida, tendo uma população comprometida com o potencial que este possui. É um município de pequeno porte com uma população total de 7.877 habitantes, de acordo com os dados levantados pelo IBGE (2000). Deste total em $2000,5.026$, ou seja, $63,80 \%$ estavam residindo na zona rural e 2.851 ou $36,19 \%$, residentes na zona urbana. Ainda conforme o IBGE (2000), 4.005, ou seja, 50,84\% são do sexo masculino e 3.872 , ou $49,15 \%$ do sexo feminino. O Município de Iporã do Oeste sofreu um decréscimo na taxa de crescimento da população em relação a 1996, de aproximadamente - $0,13 \%$, ou seja, naquela época contava com uma população total de 7.914 .

Essa queda da população no município é reflexo do que vem acontecendo em toda a região oeste do Estado de Santa Catarina. Acredita-se que vários são os fatores que explicam esta migração, principalmente do campo para a cidade. Fontana (2001, p. 49), em suas colocações, destaca algumas das causas e conseqüências desse processo migratório: na agricultura, ocorre a introdução de novas tecnologias, substituindo o trabalho humano pelas máquinas, sendo um exemplo a criação de frangos no sistema de agroindústrias.

Nos pequenos centros urbanos da região - e do município - ocorre que não há opções de trabalho para absorver a procura e os salários pagos na maioria das vezes, são insuficientes para a manutenção de uma família, por menor que ela seja. São poucas as indústrias instaladas que conseguem dar conta de absorver tal demanda e pagar um salário digno para o empregado.

Dessa forma, principalmente os jovens, saem de seu espaço construído e migram em busca de alternativas de trabalho: na construção civil, indústria, 
comércio, prestação de serviço, doméstica e estudos em centros maiores, como Chapecó-SC, Florianópolis-SC, Blumenau-SC, Curitiba-PR, São Paulo-SP e Porto Alegre-RS, ou até mesmo para outros países, como a Alemanha e Áustria, por exemplo.

O Instituto de Planejamento e Economia Agrícola (2005), com base no Levantamento Agropecuário de Santa Catarina (2002-2003), apresenta alguns dados sobre o Município de Iporã do Oeste, confirmando a afirmativa acima. Do total de 81 estabelecimentos pesquisados, sendo ouvido um total de 107 informantes, com relação ao número de pessoas que migraram nos últimos três anos, segundo o destino tomado -, constatou-se que 32 pessoas migraram para a área urbana do município, 26 se dirigiram para municípios vizinhos, 14 pessoas se deslocaram para outras regiões do Estado, 7 para os Estados da Região Sul do Brasil, 23 para outros Estados, quatro para outros países e um não declarado.

Outra característica que reflete a diminuição da população no Município de Iporã do Oeste é a redução do número de filhos por família.

O Censo Demográfico do IBGE (2000) traz alguns dados interessantes a respeito da população por faixa etária no município, conforme pode-se observar na Tabela 01.

Tabela 01 - População por faixa etária no Município de Iporã do Oeste no ano de 2000.

\begin{tabular}{ccc}
\hline Faixa etária (anos) & Número de pessoas & $\%$ \\
\hline $0-4$ & 664 & 8,42 \\
$5-9$ & 795 & 10,10 \\
$10-19$ & 1.541 & 19,57 \\
$20-29$ & 1.108 & 14,06 \\
$30-39$ & 1.274 & 16,17 \\
$40-49$ & 1.093 & 13,88 \\
$50-59$ & 635 & 8,07 \\
+ de 60 & 767 & 9,73 \\
\hline TOTAL & 7.877 & 100 \\
\hline
\end{tabular}

Fonte: Dados do Censo Demográfico 2000.

Organização: Rosangela L. Spironello, Jan/2005.

Do total de 7.877 habitantes, o maior percentual de idade encontra-se na faixa de 10 a 19 anos, com 19,57\% do total, enquanto que o menor índice encontrase na faixa de 50 a 59 anos, perfazendo um total de 8,07\%. (IBGE, 2000 apud Spironello, 2002, p. 53).

No que se refere a área da saúde, o Município de Iporã do Oeste possui um hospital com 32 leitos, inaugurado no ano de 2003, amplamente equipado para 
atender a população do município e eventualmente pessoas dos municípios vizinhos. Se considerássemos o total da população de Iporã do Oeste e a quantidade de leitos existentes, ter-se-ia um total de 246,15 habitantes/leitos.

Quanto aos profissionais da saúde, o município conta atualmente com cinco médicos e sete dentistas, os quais atendem não só a população do município, mas a população de toda a região do Extremo Oeste Catarinense. Conforme dados levantados junto à Secretaria da Saúde (2005), dos médicos, três são clínicos gerais, uma é pediatra e uma é ginecologista.

A expectativa de vida dos habitantes do município é considerada relativamente alta, alcançando uma média de 80 anos, o que nos leva a crer que a qualidade de vida das pessoas melhorou consideravelmente nos últimos anos. Conforme informações coletadas na Secretaria da Saúde do município, isso se deve principalmente ao acesso às informações no que diz respeito à qualidade de vida, com mudanças nos hábitos alimentares e a dedicação a mais horas de lazer, como encontro de idosos, onde são promovidas danças, jogos e outras descontrações.

$\mathrm{Na}$ área da educação, o município possui duas escolas municipais que atendem alunos da pré-escola até a $8^{a}$ série, uma escola localiza-se na área urbana do município e a outra localiza-se na comunidade de Linha Esperança, a qual absorve a maior parte dos alunos localizados no interior do município, uma vez que a mesma funciona sob o sistema de nuclearização.

Iporã do Oeste conta também com duas escolas estaduais, uma localizada no centro da cidade e a outra na comunidade de São Lourenço, as quais atendem alunos do ensino fundamental e médio, não sendo diferente com o CNEC Campanha Nacional das Escolas da Comunidade, localizado na área urbana.

Atualmente o Município de Iporã do Oeste registra um total de 24 comunidades distribuídas pelo seu interior. Essas comunidades caracterizam-se por uma pequena aglomeração de construções, entre as quais se resumem em algumas residências, um ginásio de esportes, uma igreja e uma escola. As principais comunidades são: São Vendelino, São Lourenço, Linha Aparecida, Preferido Alto e Macucozinho.

A área urbana destaca-se principalmente em relação aos usos residenciais, com a presença de comércio e prestação de serviço. Algumas indústrias se instalaram em Iporã do Oeste, recebendo incentivos por parte do poder público municipal, gerando maiores divisas para o município e absorvendo um contingente 
significativo de mão-de-obra da população residente da área urbana e da rural, bem como de toda a região. Destacam-se algumas empresas no setor de madeireira, móveis, beneficiamento de trigo e arroz. As Figuras 05, 06 e 07 são alguns exemplos de empreendimentos no município.

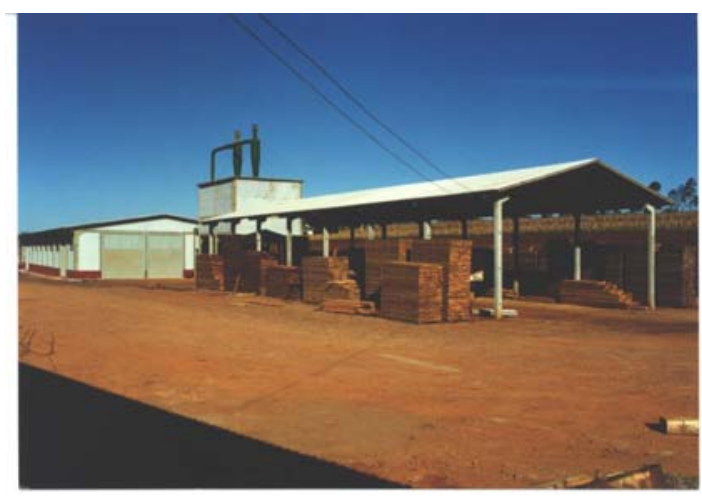

Figura 05 - Madeireira Grasel - benificiamento de madeiras, inaugurada em 1999. Organização: Rosangela L. Spironello, Jan/2005.

Fonte: Secretaria Municipal da Educação do Município de Iporã do Oeste.

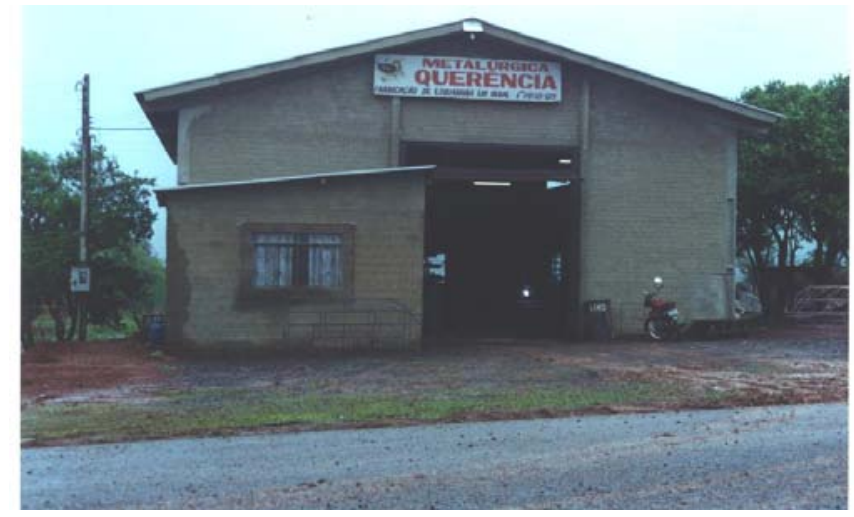

Figura 07 - Metalúrgica Querência, - fabricação de esquadrias em geral. Inaugurada no ano de 2000.

Organização: Rosangela L. Spironello, Jan/2005.

Fonte: Secretaria Municipal da Educação do Município de Iporã do Oeste.

Como os demais municípios da região do Extremo Oeste Catarinense, Iporã do Oeste tem nas atividades agropecuárias o motor propulsor da sua economia, com a produção: de milho, feijão, fumo, trigo, mandioca, cultivo de espécies frutíferas como a uva e citrus. Outras atividades como a criação de aves, suínos e bovinos de leite, garantem o desenvolvimento econômico do município. 
De acordo com os dados do Instituto de Planejamento e Economia Agrícola (2005), no Levantamento Agropecuário de Santa Catarina (2002-2003), foram produzidos no município, um total de $1.550 .090,3 \mathrm{~kg}$ de fumo, compreendendo uma área plantada de 1.096,7 ha, num total de 548 estabelecimentos. A Figura 08 (a) e (b) mostra um canteiro com as mudas cultivadas e uma área com as mudas já distribuídas na lavoura.

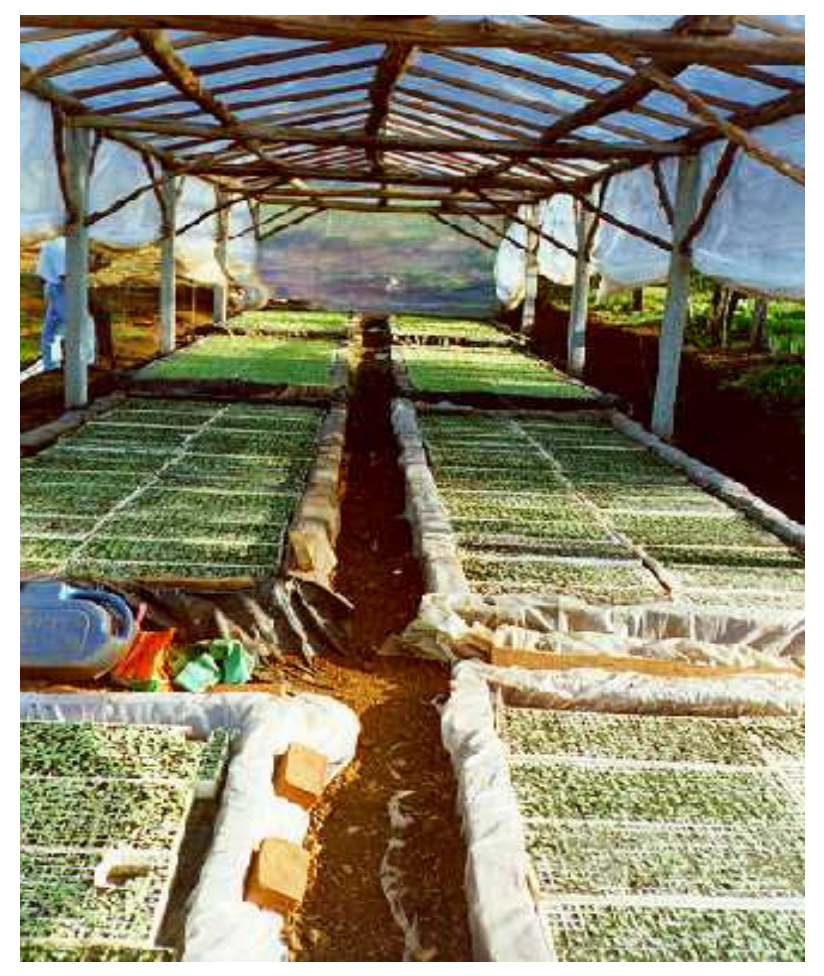

Figura 08 - (a) Canteiro com as mudas cultivadas, para posterior plantio.

Organização: Rosangela L. Spironello, Jul/2007. Fonte: Rosangela L. Spironello, Jul/2007.

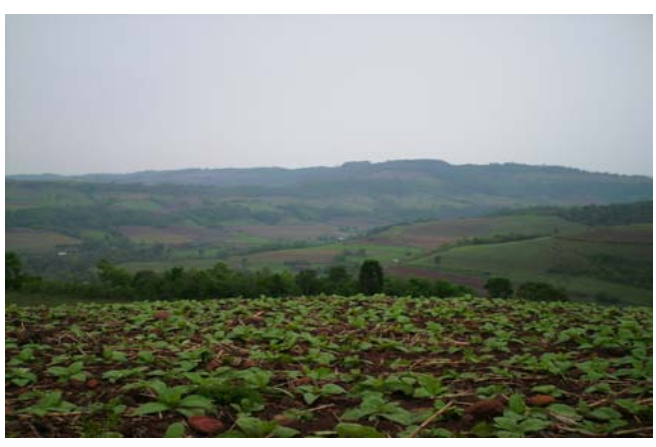

(b) Vista parcial de uma área de fumo plantada.

O milho é considerado o principal produto cultivado no município. No ano de 2002, conforme dados do $\mathrm{IBGE}^{7}$, foi produzido uma quantidade total de 27.120 toneladas de grãos. A área plantada foi de 11.300 ha, atingindo um rendimento médio de $2.400 \mathrm{~kg} / \mathrm{ha}$ de milho.

O feijão teve uma produção significativa naquele ano, com um total de 1.080 toneladas de grãos, ocupando uma área de 1.500 ha, obtendo um rendimento médio de $771 \mathrm{~kg} / \mathrm{ha}$. Outros produtos como o arroz, a mandioca, a soja e o trigo têm a sua produção em menor escala, servindo de base para a subsistência das famílias

\footnotetext{
${ }^{7}$ Informações obtidas no site < http://www.ibge.gov.br > - IBGE - Cidades@ dados do ano de 2002. Acesso em 15 de Jun/2005.
} 
produtoras, com o excedente sendo vendido no comércio local. O Quadro 01 mostra os dados sobre as culturas temporárias no município de Iporã do Oeste no ano de 2002.

Quadro 01 - Culturas temporárias no Município de Iporã do Oeste no ano de 2002.

\begin{tabular}{|l|c|c|c|}
\hline Tipo de produto & $\begin{array}{c}\text { Quantidade produzida } \\
\text { (ton) }\end{array}$ & Área plantada (ha) & $\begin{array}{c}\text { Rendimento médio } \\
\text { (Kg/ha) }\end{array}$ \\
\hline Milho (em grãos) & 27.120 & 11.300 & 2.400 \\
\hline Feijão (em grãos) & 1.080 & 1.500 & 771 \\
\hline Soja (em grãos) & 150 & 125 & 1.200 \\
\hline Trigo (em grãos) & 120 & 100 & 1.200 \\
\hline Arroz (em grãos) & 6 & 150 & 40 \\
\hline Mandioca & 1.250 & 50 & 1.250 \\
\hline
\end{tabular}

Fonte: IBGE, Produção agrícola municipal, 2002.

Organização: Rosangela L. Spironello, Jun/2005.

Com relação às culturas permanentes, o Município de Iporã do Oeste se destaca na produção de laranja e uva. Conforme as fontes do IBGE (2002), houve uma produção de 2.800 toneladas de laranja naquele ano, ocupando uma área plantada de 175 ha, atingindo assim, um rendimento médio de $16.000 \mathrm{~kg} / \mathrm{ha}$. Já a uva, obteve uma produção de 425 toneladas em 2002, numa área de 50 ha, totalizando um rendimento médio de $8.500 \mathrm{~kg} / \mathrm{ha}$.

Na pecuária, destacam-se também as atividades de criação de frangos. No ano de 2002, o Município de Iporã do Oeste contava com um total de 784.160 cabeças, incluindo aí, galos, frangos, e pintos. A maior parte da produção está vinculada ao sistema de parcerias com empresas como: a Gargill, a Aurora e a Perdigão. Nesta atividade tem-se presenciado nos últimos anos a introdução de alta tecnologia, liberando uma quantidade significativa de mão-de-obra do campo. A Figura 09 mostra a produção de frangos em sistema de parceria. 


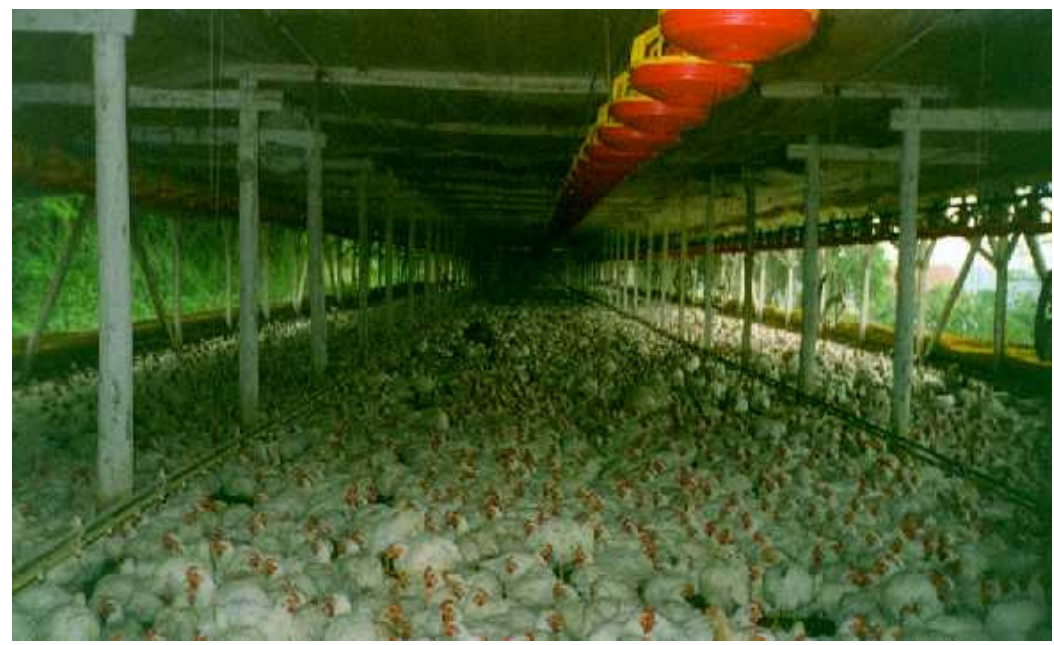

Figura 09 - Produção de frangos em sistema de parceria.

Organização: Rosangela L. Spironello. Jun/2005.

Fonte: Rosangela L. Spironello.

Outra atividade ligada ao setor de pecuária é a produção de leite. O município de Iporã do Oeste possui um total de 722 produtores, tendo sob gerenciamento um total de 4.804 vacas, que produzem anualmente, 9.691 .834 litros de leite.

Apesar de a atividade leiteira não trazer um retorno financeiro tão significativo, em função da variação de preços do produto e baixo investimento tecnológico por parte dos produtores, compreende-se que esta atividade é um complemento para a renda familiar A Figura 10 mostra o gado solto alimentando-se de pastagem.

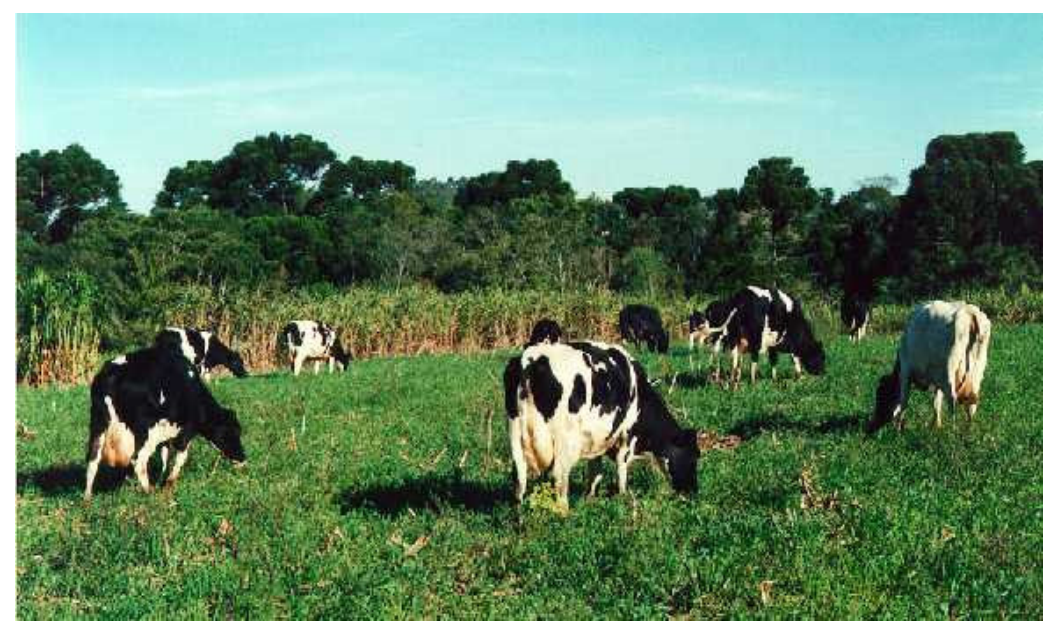

Figura 10 - Criação de gado de leite.

Organização: Rosangela L. Spironello. Jun/2005.

Fonte: Rosangela L. Spironello. 
Por outro lado, vale lembrar também que, somente alguns produtores com uma infra-estrutura mais sólida conseguem manter-se na atividade e competir no mercado.Com relação à produção de suínos, esta em outros momentos já apresentou melhores rendimentos. Com a acentuada oscilação de preços finais e a falta de uma política justa de incentivos ao produtor, houve o abandono da atividade, permanecendo nesta, somente alguns produtores com uma infra-estrutura consolidada.

No que se refere aos aspectos fundiários do município, constata-se que estes são semelhantes aos de toda a região do Extremo Oeste do Estado de Santa Catarina, com o predomínio da propriedade familiar. O Estatuto da Terra em seu Inciso II, do Artigo $4^{\circ}$, (Lei 4.504/64) define como propriedade familiar “...o imóvel rural que é direta e pessoalmente explorado pelo agricultor e sua família lhes absorva toda a força de trabalho, garantindo-Ihes a subsistência e progresso social e econômico, com área máxima fixada para cada região e tipo de exploração, e eventualmente, trabalhado com a ajuda de terceiros" ${ }^{\prime 8}$. Spironello (2002, p. 54).

Conforme a autora citada, as pequenas, médias e grandes propriedades são definidas com base no módulo fiscal, o qual serve de parâmetro para a classificação do tamanho do imóvel rural. Assim, a pequena propriedade é definida como sendo o imóvel rural de área compreendida entre 1 (um) a 4 (quatro) módulos fiscais. A média propriedade é definida como um imóvel rural de área superior a 4 (quatro) e até 15 (quinze) módulos fiscais. Sabe-se, no entanto, que cada módulo fiscal é definido pelo município, desta forma, a pequena propriedade em Iporã do Oeste abrange um total de até 80 hectares, uma vez que o módulo fiscal para o Município de Iporã do Oeste é de 20 hectares. As médias propriedades abrangem áreas de 80 a 300 hectares. Constata-se, no entanto que, ocorre o predomínio de pequenas propriedades no município e variam de 12 a 15 hectares $^{9}$.

De acordo com os dados do IBGE (2000) sobre o número de estabelecimentos por tamanho, no período compreendido entre 1975 e 1995 no Município de Iporã do Oeste, tem-se o seguinte: estabelecimentos na faixa de 10 a menos de 20 hectares, um total de 484 estabelecimentos. 372 se encontram na faixa de $<$ de 10 hectares. Os estabelecimentos de 20 a $<$ de 50 hectares constam num

\footnotetext{
${ }^{8}$ Informações coletadas do site: http://www.desenvolvimentoagrario.gov.br/faqs/incra.html\#1 em 24 de abril de 2002.

${ }^{9}$ Informações obtidas na Secretaria da Agricultura, Indústria e Comércio de Iporã do Oeste.
} 
total de 204, já os de 50 a < de 100 hectares somam um total de 14 e somente 3 se encontram na faixa de $100 \mathrm{a}<$ de 500 hectares. Esses dados totalizam 1.077 estabelecimentos em todo o município, conforme pode-se ser observado no Quadro 02.

Quadro 02 - Número de estabelecimentos por tamanho no período compreendido entre 1975 e 1995 no Município de Iporã do Oeste-SC.

\begin{tabular}{|c|c|c|c|c|c|c|c|c|c|c|c|}
\hline \multirow{2}{*}{$\begin{array}{l}\text { Tamanho } \\
\text { Período/ano }\end{array}$} & \multicolumn{2}{|c|}{$<10$ ha } & \multicolumn{2}{|c|}{$10 \mathrm{a}<20 \mathrm{ha}$} & \multicolumn{2}{|c|}{$20 \mathrm{a}<50 \mathrm{ha}$} & \multicolumn{2}{|c|}{$\begin{array}{l}50 a<100 \\
\text { ha }\end{array}$} & \multicolumn{2}{|c|}{$\begin{array}{l}100 \mathrm{a}<500 \\
\text { ha }\end{array}$} & \multirow[t]{2}{*}{ Total } \\
\hline & 75 & 95 & 75 & 95 & 75 & 95 & 75 & 95 & 75 & \begin{tabular}{|l|}
95 \\
\end{tabular} & \\
\hline $\mathrm{N}^{\circ}$ de estab. & - & 372 & - & 484 & - & 204 & - & 14 & - & 03 & 1077 \\
\hline
\end{tabular}

Fonte: IBGE, 2000.

Organização: Rosangela L. Spironello, Jan/2005.

Com base nesses dados, percebe-se que há o predomínio da pequena propriedade, a qual reflete claramente a condição do produtor. De acordo com os dados extraídos do Instituto de Planejamento e Economia Agrícola (2005), através do Levantamento Agropecuário de Santa Catarina (2002-2003, p. 39), pode-se dizer que do total de 1.053 estabelecimentos levantados, 943 são de proprietários com título de posse e 65 estabelecimentos constam sem título de posse. Na condição de arrendatários tem-se um total de 38 estabelecimentos. Já na condição de parceiros são 7 estabelecimentos na sua totalidade, não verificando-se a condição de ocupantes no município.

Essas informações mostram a condição do produtor no Município de Iporã do Oeste, onde a mão-de-obra familiar ainda é empregada, característica do modo de apropriação do espaço empregado no início da colonização em toda a região do Estado.

Apesar de ter uma estrutura e organização com base na mão-de-obra familiar, percebe-se que cada vez mais esta se encontra escassa, em função principalmente do abandono dos jovens da atividade na agropecuária, conforme já destacado anteriormente. 


\section{4 - MATERIAIS E PROCEDIMENTOS METODOLÓGICOS}

\section{1 - MATERIAIS}

Para a realização da presente pesquisa utilizou-se dos seguintes materiais: Programas: Spring 4.2.1, Word 2003, Corel Draw 12. Equipamentos: Processador Pentium 5 - 512 Mb. Equipamentos: Gravadora de CD-Rom e DVD, Drives de multimídia, Scanner de mesa, Máquina fotográfica digital.

Documentos cartográficos como: cartas topográficas adquiridas na $1^{\underline{a}}$ Divisão de Levantamentos do Exercito de Porto Alegre-RS; imagens de satélites capturadas no site do INPE (Instituto de Nacional de Pesquisas Espaciais) em São José dos Campos-SP.

\section{2 - PROCEDIMENTOS METODOLÓGICOS}

A partir da percepção e conscientização de que se necessita pensar o espaço, planejar e organizar estratégias de desenvolvimento adequado, buscou-se nesta pesquisa, apresentar uma metodologia de análise espacial por meio de zoneamento, o qual absorvesse todos os elementos constituintes do espaço geográfico (sociais, culturais, econômicos e ambientais), para assim levantar, analisar, discutir e apresentar uma proposta coerente de desenvolvimento para o Município de Iporã do Oeste-SC.

Desta forma, a presente pesquisa fundamentou-se na metodologia proposta por Libault (1971), o qual aborda "Os Quatro Níveis da Pesquisa Geográfica": Nível Compilatório, Correlatório, Semântico e Normativo. Assim sendo, serão descritas as etapas da pesquisa a seguir:

Nível Compilatório - é a fase inicial do trabalho, o qual foi feito o levantamento de campo e a obtenção de materiais, como cartas topográficas, imagens de satélites e fontes bibliográficas sobre o tema pesquisado.

Nesta fase fez-se a seleção da área de estudo, o Município de Iporã do Oeste-SC e os mapas a serem elaborados, definindo uma escala aproximada de 1 : 
110.000 para os mapas do município e 1:40:000 para mapas das microbacias hidrográficas.

A escolha do referido município como objeto de estudo desta tese, justificase pelo fato de se ter a necessidade de refletir e aprofundar as análises sobre a utilização adequada do espaço geográfico, adequando-se às potencialidades e as limitações físicas e socioeconômicas existentes na área de estudo, visando um desenvolvimento local "sustentável", com qualidade de vida para a população inserida neste espaço.

Assim, a proposta deste trabalho de pesquisa teve em vista, elaborar um Zoneamento-Antrópico-Ambiental a partir de análises das microbacias hidrográficas no município. Optou-se em trabalhar com microbacias hidrográficas por considerar que as mesmas são células espaciais básicas de análise ambiental, as quais permitem que se conheça e se avalie todos os componentes e processos que ocorrem em seu interior, de forma interligada, como um geossistema.

Por conseguinte, decidiu-se manter a divisão das microbacias estabelecidas pelo Projeto Microbacias II do Governo do Estado de Santa Catarina. O referido projeto teve início no ano de 2002 e tem a perspectiva de prorrogação até 2010 . Algumas informações a respeito das questões ambientais e socioeconômicas de parte das microbacias hidrográficas foram levantadas e já avançaram, as quais estão compiladas e fizeram parte das análises e discussões desta tese.

Posto que são no total de nove microbacias hidrográficas que cobrem a área do município, o objetivo foi fazer o levantamento das informações - fatores socioeconômicos e ambientais - , de duas microbacias com realidades parcialmente distintas no que se refere aos aspectos citados, sendo a microbacia hidrográfica do Lajeado Pirapó (MHLP) e a microbacia hidrográfica do Lajeado Esperança (MHLE).

Da mesma forma, buscou-se a partir dos trabalhos de campo e em conversas informais, contribuições e perspectivas por parte da população, para assim, operacionalizar e sistematizar a efetivação da proposta de ZoneamentoAntrópico-Ambiental, para cada unidade de análise. Assim, as etapas da elaboração do ZAA estarão descritas nos níveis a seguir, propostos por Libault (1971).

Com relação às fontes bibliográficas, bem como a documentação cartográfica necessária para o mapeamento, suas aquisições nos permitiram observar detalhes da área de estudo com relação aos fatores físicos, humanos e 
sociais, possibilitando verificar, inicialmente, a problemática que envolve esta pesquisa.

Para alicerçar as bases conceituais e temáticas da pesquisa realizou-se uma ampla revisão de literatura a respeito do processo histórico de ocupação, fatores físicos e socioeconômicos do Estado de Santa Catarina, região e município. O levantamento bibliográfico foi realizado junto aos órgãos públicos - universidades, Secretaria da Educação do Município de Iporã do Oeste, bem como pesquisas desenvolvidas pela internet.

\subsection{1 - Elaboração dos mapas de uso da terra do Município de Iporã do Oeste- SC}

Para a elaboração dos mapas de uso da terra foram utilizadas as informações do banco de dados georreferenciados, gerados por Spironello (2002) a partir do software Idrisi 3.2. As classes de uso da terra delimitadas para o mapeamento do ano de 1978 e 1997 foram: culturas (milho, feijão, soja, trigo e fumo), florestas (nativas e exóticas), campos (pastagens, vegetação arbustiva e subarbustiva), área urbana e não classificado (nuvens). Já para o mapeamento do ano de 2007 foram consideradas as classes de culturas, campos, florestas, área urbana e água (incluindo os açudes, lagos, rios e lajeados).

Para a elaboração do mapa de uso da terra do ano de 1978, a autora citada utilizou-se de fotografias aéreas infra-vermelho na escala de 1:45.000. Para a confecção do mapa de uso da terra, inicialmente, foi elaborado um mosaico aerofotogramétrico no programa Photoshop. Posteriormente, foi feita a georreferência do mesmo no programa Tnt mips, o qual foi acrescentado os vetores de rede de drenagem e rede viária, limites, nome das localidades, divisas e coordenadas UTM, que já haviam sido digitalizados. Após o georreferenciamento, este foi importado para o Idrisi 3.2, onde foi efetuada a digitalização e a quantificação das classes de usos da terra. A edição final foi feita no programa Corel Draw 10. (SPIRONELLO, 2002, p. 25-26)

Já para a elaboração do mapa de uso da terra de 1997, Spironello (2002), utilizou-se de uma imagem de satélite Landsat-5 bandas 3, 4, e 5, datada do mês de Outubro. Optou-se pela classificação digital supervisionada com o auxílio do método 
da máxima verossimilhança. Crósta (1993, p. 119) esclarece que este método é “...o método mais comum que considera a ponderação das distâncias das médias, que utiliza parâmetros estatísticos e matemáticos". Desta forma, foram coletadas aproximadamente $5 \%$ de amostras de cada categoria de uso da terra para a classificação. Os dados foram classificados e processados no Idrisi 3.2, e foram adicionados os arquivos vetoriais de estradas, drenagens e limites, além de elementos como coordenadas UTM, nome das principais comunidades, rios e divisas. A edição final do produto foi realizada no programa Corel Draw 10. É importante destacar que os mapas de uso da terra de 1978 e 1997, elaborados por Spironello (2002), foram posteriormente reeditados no software Spring 4.2.1, para ter-se um único padrão de apresentação dos produtos cartográficos.

O mapa de uso da terra de 2007, foi elaborado em meio digital, com base na imagem do satélite CBERS, de Janeiro 2007, bandas 2, 3 e 4. A composição 2, 3 e 4 foi escolhida por discriminar de maneira clara os limites entre as classes.

Para efetuar a classificação digital de imagens, inicialmente realizou-se o georreferenciamento utilizando 18 pontos de controle.

$\mathrm{Na}$ classificação da imagem optou-se pela classificação digital supervisionada e parâmetros estatísticos de Máxima Verossimilhança com classificação "pixel a pixel". Partiu-se inicialmente coletando amostras sobre a área a ser classificada, sendo que as mesmas serviram de base para que o programa realizasse a classificação.

As classes de uso da terra foram estabelecidas com base no objetivo do trabalho, o qual possibilitou identificar os principais usos da terra na área em estudo. Assim, identificou-se um total de cinco classes de uso da terra, sendo elas: culturas, campos, florestas, águas e área urbana. Vencida a etapa de classificação, partiu-se para a edição (toponímia) do mapa no Aplicativo Scarta e posteriormente, no Corel Draw 12.

\subsection{2 - Elaboração dos mapas de uso da terra das microbacias hidrográficas do Lajeado Pirapó e Lajeado Esperança.}

Para o mapeamento das microbacias hidrográficas, inicialmente, optou-se por respeitar os limites estabelecidos pelo Projeto Microbacias II, considerando os 
divisores de água. Para tal, o mapeamento foi executado de forma simples, uma vez que o município já apresentava os dados espacializados e quantificados, numa base de dados gerreferenciados. Com isso, buscou-se fazer a delimitação das microbacias hidrográficas e inserí-las nas coordenadas UTM a partir do georeferenciamento no software Spring 4.2.1. Como resultado final obteve-se, de forma particular, valores específicos de usos da terra para as referidas microbacias, dentro da mesma dinâmica de mapeamento elaborado para o município. Posteriormente, os produtos cartográficos foram editados no Corel Draw 12.

\subsection{3 - Elaboração do mapa clinográfico do Município de Iporã do Oeste-SC}

O mapa clinográfico foi elaborado com base na metodologia de De Biasi (1992). As classes usadas para o mapeamento ficaram assim definidas: < de $5 \%$, de $5-12 \%, 12-30 \%, 30-47 \%$ e > de 47\%. Para obter uma melhor definição nos dados de mapeamento das classes de declividade, Spironello (2002), elaborou o mapa clinográfico de forma analógica, utilizando-se do ábaco, com as classes acima descritas. Para melhor compreender a dinâmica do espaço geográfico, a autora apoiou-se em Lepesch (2002) e EMBRAPA (1995), caracterizando as classes de declividade, conforme mostra o Quadro 03.

Após a elaboração do mapa clinográfico sob a forma analógica, o mesmo foi escaneado e o arquivo gerado foi importado para o Idrisi 3.2. Posteriormente, as classes de declividade foram digitalizadas em forma de polígonos, das quais obtevese a área em hectares e a porcentagem total de cada classe. A edição final do produto foi feita no programa Corel Draw 12. Da mesma forma, este mapa foi reeditado no software Spring 4.2.1 para obter o mesmo padrão final dos demais produtos cartográficos. 
Quadro 03 - Classes de declividade definidas para a pesquisa.

\begin{tabular}{|c|c|c|c|}
\hline $\begin{array}{l}\text { Classes } \\
(\%)\end{array}$ & Características de uso & $\begin{array}{l}\text { Características } \\
\text { do relevo }\end{array}$ & Considerações gerais \\
\hline$<5$ & Limite urbano industrial. & Planos & $\begin{array}{l}\text { Solos em áreas planas com pouca } \\
\text { suscetibilidade à erosão. }\end{array}$ \\
\hline $5-12$ & $\begin{array}{l}\text { E o limite máximo para o } \\
\text { emprego de mecanização na } \\
\text { agricultura. }\end{array}$ & $\begin{array}{|ll|}\text { Planos } & \text { com } \\
\text { suaves } & \\
\text { ondulações } & \\
\end{array}$ & $\begin{array}{l}\text { Solos em áreas com suaves } \\
\text { ondulações, apresentam pouca } \\
\text { suscetibilidade à erosão. } \\
\text { Práticas de manejo e conservação do } \\
\text { solo podem prevenir alguns } \\
\text { processos erosivos que possam vir a } \\
\text { ocorrer. }\end{array}$ \\
\hline $12-30$ & $\begin{array}{l}\text { Limite máximo para } \\
\text { urbanização sem restrições, a } \\
\text { partir do qual toda e qualquer } \\
\text { forma de parcelamento far-se-á } \\
\text { através de exigências } \\
\text { específicas. }\end{array}$ & $\begin{array}{l}\text { Superfícies } \\
\text { inclinadas }\end{array}$ & $\begin{array}{l}\text { Solos nessas superfícies apresentam } \\
\text { forte suscetibilidade à erosão. As } \\
\text { práticas de manejos e conservação } \\
\text { devem ser orientadas desde o } \\
\text { princípio da utilização para a } \\
\text { agricultura, evitando assim, o } \\
\text { aparecimento de sulcos ou voçorocas. }\end{array}$ \\
\hline $30-47$ & $\begin{array}{l}\text { E o limite máximo para o corte } \\
\text { raso, a partir do qual a } \\
\text { exploração só será permitida } \\
\text { se sustentada por cobertura } \\
\text { florestal. }\end{array}$ & $\begin{array}{l}\text { Declives } \\
\text { acentuados }\end{array}$ & $\begin{array}{l}\text { Área considerada de conservação } \\
\text { permanente pelo Código Florestal. A } \\
\text { utilização do solo para atividades } \\
\text { agrícolas se torna restrita. }\end{array}$ \\
\hline$>47$ & $\begin{array}{l}\text { Esta declividade não permite a } \\
\text { derrubada de florestas, } \\
\text { somente é tolerada a extração } \\
\text { de toros, quando em regime de } \\
\text { utilização racional que vise } \\
\text { rendimentos permanentes. }\end{array}$ & $\begin{array}{l}\text { Declives } \\
\text { fortemente } \\
\text { acentuados }\end{array}$ & $\begin{array}{l}\text { Áreas destinadas à preservação } \\
\text { ambiental de acordo com o Código } \\
\text { Florestal Brasileiro Lei número } 4.771 \\
\text { de } 1965 \text {. } \\
\text { Não recomendável para a utilização } \\
\text { agrícola, com intenso potencial à } \\
\text { erosão. }\end{array}$ \\
\hline
\end{tabular}

De Biasi, (1992); EMBRAPA (1995); Lepesch (2002).

Organização: Rosangela L. Spironello, Jan/2005.

\subsection{4 - Elaboração dos mapas clinográficos das microbacias hidrográficas do Lajeado Pirapó e Lajeado Esperança}

Para obter os mapas das referidas microbacias, inicialmente as cartas topográficas foram transferidas do modo analógico para digital raster via scaner. Em meio digital fez-se o mosaico das cartas topográficas com o programa computacional Corel Draw 12. No programa computacional Impima, fez-se a mudança do arquivo TIFF para GRIB e no Programa Computacional Spring 4.2.1 - Sistema de Processamento de Informações Georreferenciadas -, realizou-se o registro georreferenciamento - da imagem para posteriormente fazer a digitalização, via tela do computador, dos seguintes planos de informação: limite da área, estradas, rede de drenagem e vias urbanas. A edição (toponímia) do mapa foi realizada por meio 
do Aplicativo Computacional Scarta na versão 4.2.1 desenvolvido pelo Instituto Nacional de Pesquisas Espaciais (INPE) e Corel Draw 12.

\subsection{5 - Elaboração dos mapas hipsométricos das microbacias hidrográficas do Lajeado Pirapó e Lajeado Esperança}

As cartas topográficas elaboradas pela DSG, nos permitiram definir quatro classes hipsométricas, espacializadas de 60m em 60m (salvo a última classe definida para a microbacia hidrográfica do Lajeado Esperança, que ficou estabelecida de $80 \mathrm{~m}$ ). Definidas as classes, partiu-se para a sua confecção sob a forma analógica, pintando cada classe manualmente. Posteriormente, as cartas foram escaneadas e importadas para o Software Spring 4.2.1. Em seguida transferiu-se as imagens para o formato digital. No aplicativo Impima do SIG Spring, fez-se a mudança do arquivo TIFF para GRIB, e no Programa Computacional Spring 4.2.1 (Sistema de Processamento de Informações Georreferenciadas) elaborou-se o banco de dados. Fez-se nessa seqüência o registro (georreferenciamento) da imagem do mapa hipsométrico para posteriormente fazer a digitalização, via tela do computador, das classes hipsométricas. A edição final dos mapas foi realizada por meio do aplicativo Scarta do Spring e Corel Draw 12.

Nível correlatório - esta fase corresponde a correlação dos dados para sua posterior interpretação, é uma operação importante e seletiva. Neste sentido, foram elaborados os mapas de legislação ambiental para correlacionar com o uso da terra de cada microbacia hidrográfica selecionada, para analisar os conflitos e potencialidades de cada unidade de análise. Paralelamente, fez-se a correlação dos dados obtidos a partir dos relatórios efetuados pelo grupo que compõe cada microbacia.

\subsection{6 - Elaboração dos mapas de legislação ambiental das microbacias hidrográficas do Lajeado Pirapó e Lajeado Esperança}

O mapa de legislação ambiental das microbacias hidrográficas do Lajeado Pirapó e do Lajeado Esperança foram confeccionadas a partir das cartas 
topográficas elaboradas pelo DSG, tendo por base a rede hidrográfica e as classes de declividade. Assim, os mapas foram elaborados tendo como base o Código Florestal Brasileiro, Lei $N^{\circ} 4.771$ e de acordo com a realidade da área de estudo. $\mathrm{O}$ mapa de legislação elaborado considerou as áreas de preservação permanente, os cursos de água com área marginal de $30 \mathrm{~m}$, as nascentes com raio de $50 \mathrm{~m}$, declividades acima de $47 \%$.

Nível semântico - é a fase em que as informações são interpretadas, indicando assim os dados conclusivos. Com base nas correlações feitas nas fases anteriores foi possível estabelecer os devidos parâmetros para a pesquisa. Nesta fase, foram elaborados os mapas de conflitos ambientais de cada microbacia delimitada.

\subsection{7 - Elaboração dos mapas de conflitos ambientais das microbacias hidrográficas do Lajeado Pirapó e Lajeado Esperança}

$\mathrm{Na}$ elaboração dos mapas de conflitos ambientais das microbacias hidrográficas do Lajeado Pirapó e Lajeado Esperança, foram consideradas as classes de uso da terra do ano de 2007 e o mapa de legislação ambiental. A sobreposição dos planos de informação foi efetuada no software Spring 4.2.1. Assim, selecionou-se as classes de uso da terra que estão em conflitos em relação à legislação ambiental. As classes que se encontram em conflito na área de estudo são as seguintes: culturas em declividades $>47 \%$, culturas em drenagem $(30 \mathrm{~m})$ e nascentes $(50 \mathrm{~m})$. Campos em declividades $>47 \%$, campos em drenagem $(30 \mathrm{~m})$ e nascentes $(50 \mathrm{~m})$. Urbano em declividades > 47\%, urbano em drenagem $(30 \mathrm{~m})$ e nascentes $(50 \mathrm{~m})$.

Nível normativo - é a fase final do trabalho. O resultado da pesquisa foi apresentado sob a forma de um mapa de zonas homogêneas definido inicialmente como Zoneamento Ambiental, o qual foi relacionado com as informações levantadas pela população de cada área de estudo, propondo um cenário desejado para cada microbacia, considerando as necessidades de projetos do público alvo. 


\subsection{8 - Zoneamento-Antrópico-Ambiental (ZAA) das microbacias hidrográficas do Lajeado Pirapó e Lajeado Esperança}

A proposta de Zoneamento-Antrópico-Ambiental (ZAA) consistiu inicialmente, na elaboração dos diferentes produtos cartográficos, na escala de 1:40:000, os quais foram confeccionados no Software Spring 4.2.1, e editados no Corel Draw 12, conforme descrito acima. Assim, o mapa final de Zoneamento caracterizou-se como ZA. Paralelamente, foram levantadas junto à prefeitura municipal, no órgão da Epagri, todas as informações sobre os fatores socioculturais registrados em relatórios do Projeto Microbacias II. Os documentos (relatórios) foram analisados cuidadosamente e, a partir deles pôde-se levantar as perspectivas da população com relação à área de estudo a qual estão inseridas. Com o Zoneamento elaborado, verificou-se se os projetos ou perspectivas elencadas pela população poderia ser incentivada naquele determinado espaço, face a característica da zona delimitada. Por fim, com o cenário atual configurado, bem como o cenário a ser projetado e incentivado foi gerado em forma de quadro síntese, acompanhado, na seqüência das diretrizes gerais para cada área de estudo delimitada. Na Figura 11 é apresentado o fluxograma com as etapas metodológicas para a elaboração da proposta de Zoneamento-Antrópico-Ambiental (ZAA) para a área de estudo.

Nesse contexto, para a definição do Zoneamento-Antrópico-Ambiental, foi utilizado o embasamento metodológico proposto por Rocha (1997, p. 178-179), onde foram definidas as classes de uso e ocupação do espaço. As classes definidas são: (ZUOR) Zona de Uso e Ocupação Restrita, (ZUOM) Zona de Uso e Ocupação Moderada e (ZUOC) Zona de Uso e Ocupação Controlada.

Após a definição das zonas, fez a sobreposição dos planos de informação (declividades, hipsometria, uso da terra e legislação), de forma manual, com o auxílio de uma mesa de luz, identificando os espaços com características semelhantes ou até mesmo com as particularidades existentes em cada uma das áreas de estudo. Vale destacar que o conhecimento sobre a área de estudo por parte da pesquisadora e os trabalhos de campo auxiliaram também na delimitação das zonas de uso e ocupação, não perdendo de vista o encaminhamento metodológico proposto por Rocha (1997).

De posse dessas informações, as zonas geradas a partir dos mapas foram escaneadas e digitalizadas e importadas para o software Spring 4.2.1. Em seguida, 


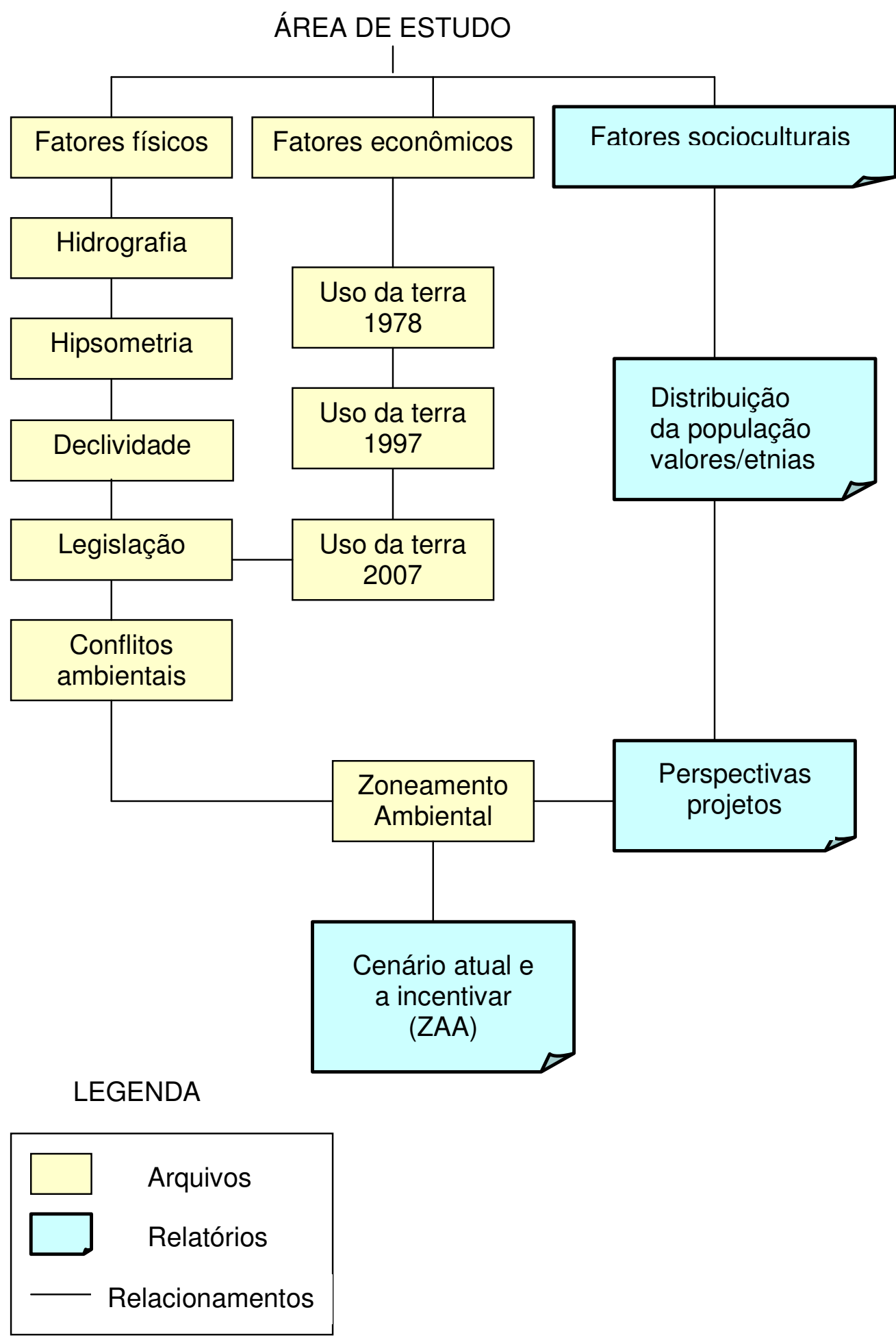

Figura 11 - Fluxograma envolvendo as etapas metodológicas para a elaboração da proposta de Zoneamento-Antrópico-Ambiental para as microbacias hidrográficas do Lajeado Pirapó e Lajeado Esperança, Município de Iporã do Oeste-SC. 
fez-se a transferência das imagens para o formato digital. No aplicativo Impima do SIG Spring, efetuou-se a mudança do arquivo TIFF para o arquivo GRIB, e no Spring 4.2.1 elaborou-se 0 banco de dados. Fez-se nessa seqüência o registro (georreferenciamento) da imagem do mapa das zonas homogêneas, para posteriormente fazer a digitalização na tela do computador, das zonas estabelecidas. A edição final dos produtos cartográficos foi realizada por meio do aplicativo Scarta do SIG Spring e Corel Draw 12.

No que se refere aos cenários identificados para cada zona, pode-se dizer que estes seguiram uma análise lógica-intuitiva, a qual não buscou nenhum aporte em métodos matemáticos, mas está embasada na resposta, a partir das sobreposições (uso da terra, declividades, hipsometria e legislação), que o próprio zoneamento mostrou e no conhecimento e experiência da pesquisadora possui referente a área de estudo.

A partir daí, já com o cenário atual configurado a partir do zoneamento, analisou-se os projetos ou perspectivas que a população de cada microbacia havia estabelecido como prioridade. Dos projetos elencados pela população, estes foram analisados cuidadosamente e verificadas as possibilidades de implantação para cada zona definida, diante da realidade refletida no zoneamento e no próprio contexto socioeconômico em que as microbacias se encontram, denominando-a de Zoneamento-Antrópico-Ambiental.

Por fim, foram apresentadas algumas diretrizes ou encaminhamentos para as áreas de estudo, destacando a importância do papel da população e do poder público na efetivação e sistematização dos projetos, mantendo um equilíbrio com o desenvolvimento socioeconômico e a qualidade ambiental e de vida. 


\section{5 - ANÁLISES E DISCUSSÕES DOS RESULTADOS}

\section{1 - USO DA TERRA NO MUNICÍPIO DE IPORÃ DO OESTE-SC}

No planejamento ambiental, o uso da terra é caracterizado como um tema básico, uma vez que expressa o reflexo da ação do homem sobre o espaço geográfico. Por isso, identificar, caracterizar e analisar o uso da terra num determinado espaço é de fundamental importância para a incorporação de ações de manejo e utilização adequada dos recursos naturais. Assim, o conhecimento acerca dos diferentes usos da terra nos possibilita, sobretudo, analisar os potenciais e as limitações de usos, orientando as tomadas de decisões por parte dos planejadores e pesquisadores.

Vale lembrar ainda, que qualquer estudo que envolva padrões espaciais de

usos e os processos que se dão nesse espaço, deve considerar a dinâmica socioeconômica e cultural incorporada na paisagem, construída ao longo da história de ocupação e apropriação.

Sabe-se, historicamente, que desde o início do processo de ocupação do Município de Iporã do Oeste, o colonizador empreendeu práticas de utilização do espaço geográfico de forma predatória, inicialmente com o processo de extração da madeira para a exportação, e posteriormente abrindo espaços para o avanço da atividade agropecuária.

Para compreender essa dinâmica socioespacial no Município de Iporã do Oeste, foi realizado o mapeamento do uso da terra, abordando e analisando os principais conflitos de usos existentes nesse espaço. Dessa forma, com base nas fontes de Spironello (2002), foi efetuado o mapeamento do uso da terra do ano de 1978 e 1997, com fotos aéreas infra-vermelho, na escala de 1: 45.000 e imagem de satélite Landsat 5, bandas 3, 4 e 5 . As classes de uso da terra definidas para o referido mapeamento foram: florestas, campos, culturas, área urbana e não classificado.

Com o mapeamento do uso da terra do ano de 1978, a autora acima citada constatou que o Município de Iporã do Oeste apresentava, naquela época, 7.767,59 ha, ou seja, $38,8 \%$ da área total do município de florestas, as quais compreendem 
todos os tipos de vegetação arbórea: mata nativa, floresta exótica, capoeira e capoeirões.

No que se refere às áreas de campos, (classificado como vegetação herbácea e subarbustiva, naturais ou implantadas), estas ocupavam um total de $7.472,76$ ha, representando $37,3 \%$, do território do município, praticamente igualando-se à classe de uso da terra florestas. Conforme destaca Spironello (2002, p. 61):

Esta quantidade expressiva de área ocupada por campos justifica-se porque, naquela época, os agricultores deixavam as terras mais planas para crescer a vegetação subarbustiva para soltar o gado (nos chamados potreiros), assim, as áreas de encostas eram utilizadas para a prática da agricultura por haver um solo mais fértil. Com o passar dos anos, esta área cede espaço para as atividades destinadas aos cultivos agrícolas de forma bastante intensa, motivada pela ampliação da mecanização na agricultura e incentivos governamentais.

A classe de uso da terra culturas (a qual compreende os cultivos agrícolas com culturas anuais cíclicas de milho, de feijão e soja), ocupava um total de $4.564,57$ ha, ou seja, $22,8 \%$ da área do município.

As demais classes de uso da terra, como a área urbana e não classificado (são áreas cobertas por nuvens e/ou manchas), apresentavam uma porcentagem relativamente baixa em relação as demais. A Tabela 02 e Figura 12 mostram a quantificação e a classificação do mapeamento do uso da terra do ano de 1978, realizado por Spironello (2002).

Tabela 02 - Distribuição das classes de uso da terra no Município de Iporã do Oeste no ano de 1978.

\begin{tabular}{lrc}
\hline Classes & Área (ha) & $\%$ \\
\hline Culturas & $4.564,57$ & 22,8 \\
Campos & $7.472,76$ & 37,3 \\
Florestas & $7.767,59$ & 38,8 \\
Área Urbana & 75,92 & 0,5 \\
Não Classificado & 128,78 & 0,6 \\
\hline TOTAL & $20.009,62$ & 100 \\
\hline
\end{tabular}

Organização: Rosangela L. Spironello, Dez/2005.

Fonte: Spironello, 2002, p. 61. 


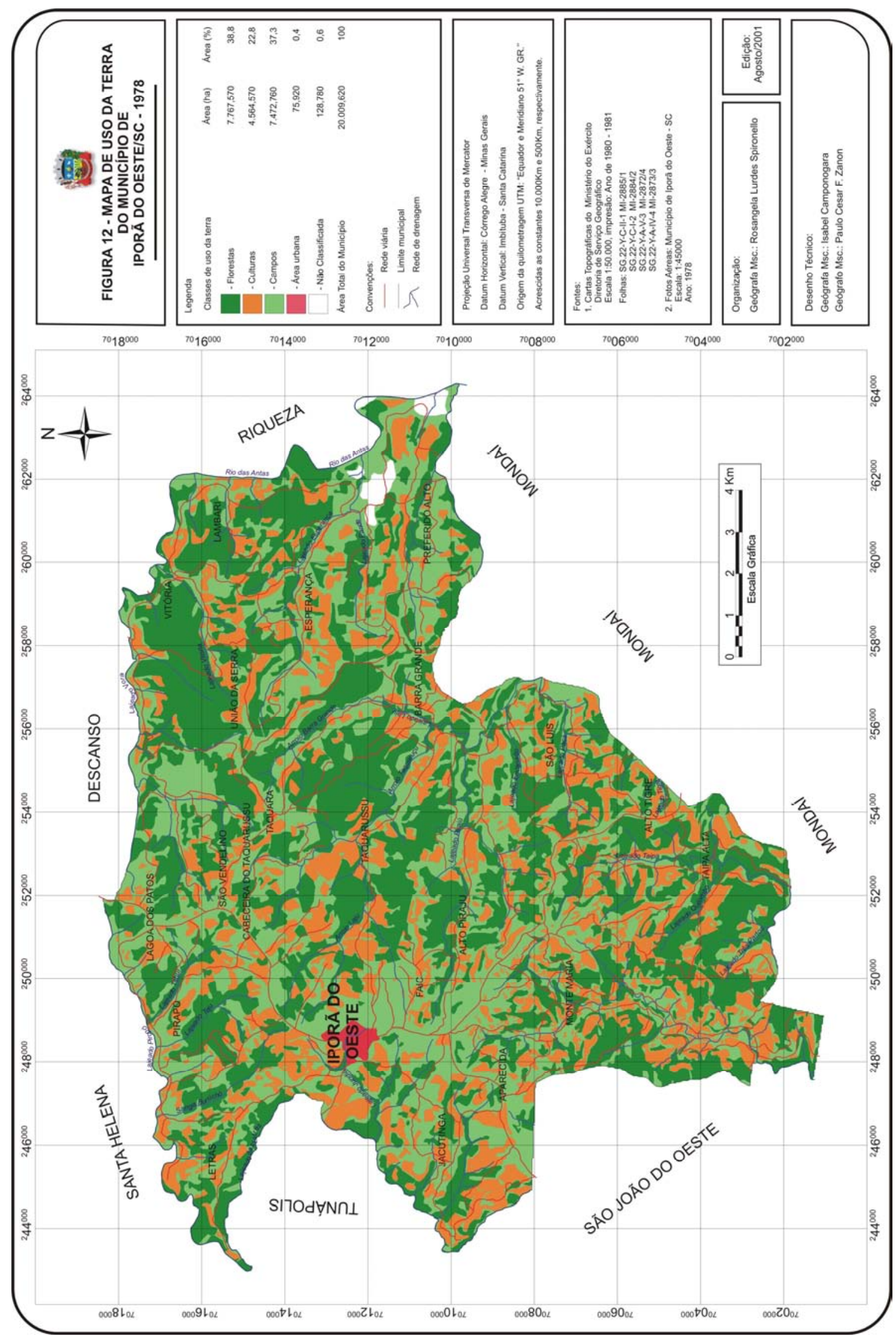


Com base na classificação do uso da terra do ano de 1997, elaborado a partir da imagem de satélite Landsat 5, bandas 3, 4, e 5, foi constatado pela autora que houve uma inversão em alguns dos usos da terra no Município de Iporã do Oeste.

A classe de uso culturas predominava com um total de 11.672,33 ha, ou seja, 58,3\% da área do município.

A classe de uso da terra representada pelas florestas ocupava a segunda maior extensão de terras, com 5.625,43 ha, ou seja, $28,1 \%$ da área total do Município de Iporã do Oeste.

$\mathrm{Na}$ tabela 03 tem-se a distribuição das classes de usos da terra no ano de 1997, no Município de Iporã do Oeste-SC.

Tabela 03. - Distribuição das classes de uso da terra no Município de Iporã do Oeste no ano de 1997.

\begin{tabular}{lcc}
\hline Classes & Área (ha) & $\%$ \\
\hline Culturas & $11.672,33$ & 58,3 \\
Campos & $2.505,77$ & 12,5 \\
Florestas & $5.625,43$ & 28,1 \\
Área Urbana & 176,00 & 0,9 \\
Não Classificado & 30,09 & 0,2 \\
\hline TOTAL & $20.009,62$ & 100 \\
\hline
\end{tabular}

Organização: Rosangela L. Spironello, Dez/2005.

Fonte: Spironello, 2002, p. 66.

Conforme a tabela acima, a classe de uso da terra representada pelos campos, aparece com 2.505,77 ha, ou $12,5 \%$ da área total do município. A área urbana ocupava no ano de 1997, 176,00 ha, totalizando 0,9\% da área do município. Por fim, a classe de uso da terra representada por não classificado, a qual abrangia 30,09 ha, ou 0,2\% do total da área do município, Spironello (2002). Com base na Figura 13, pode-se observar a espacialização do uso da terra no ano de 1997, no Município de Iporã do Oeste.

Diante dessas colocações pode-se perceber as significativas alterações que ocorreram no espaço geográfico do Município de Iporã do Oeste durante esse período. Constatou-se a partir da análise, que a principal mudança ocorreu com o uso da terra culturas. Esta classe ocupava $22,8 \%$ da área total do município em 1978, e em 1997 passa a alcançar um total de 58,3\%. 


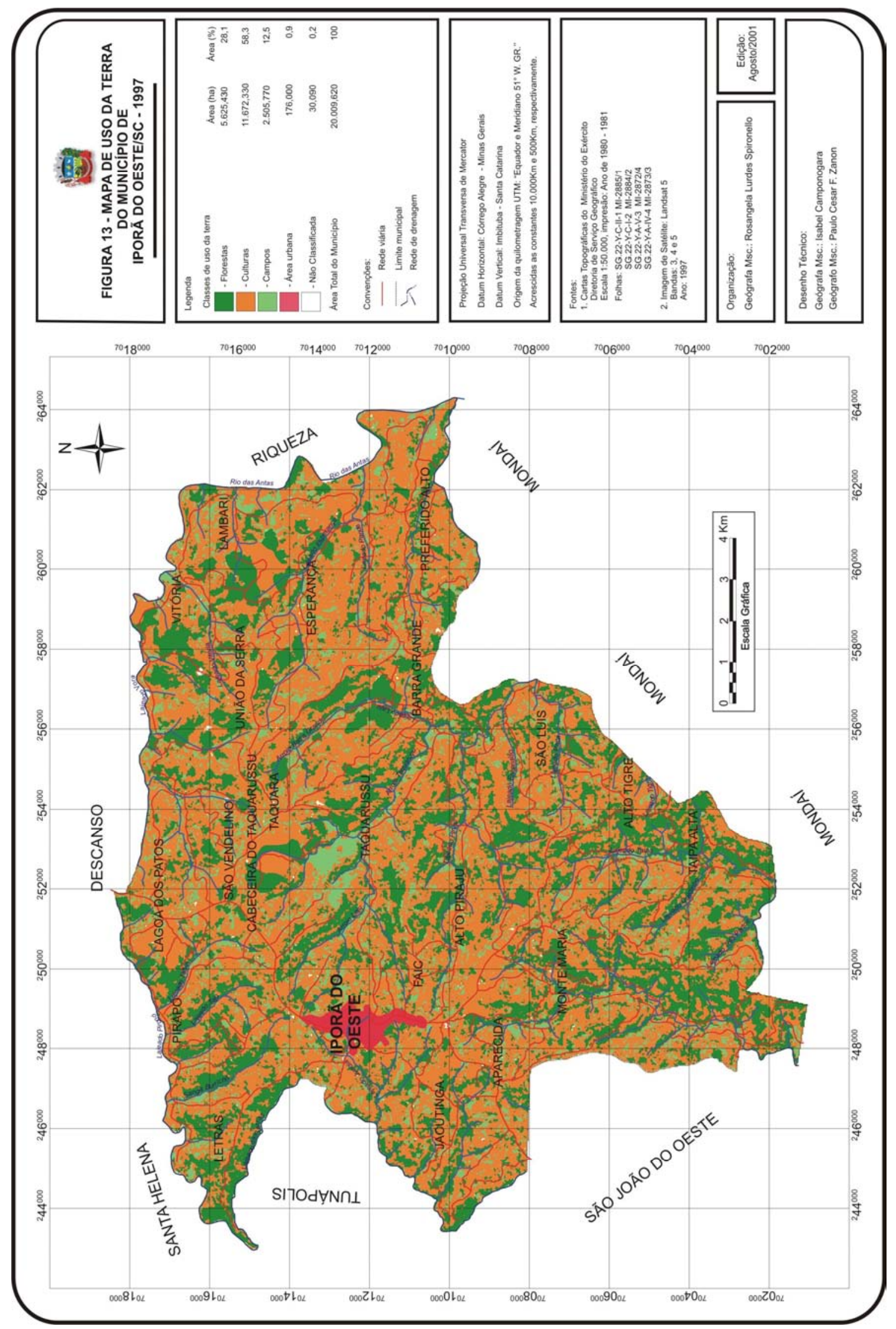


A classe de uso da terra campos, que ocupava $37,2 \%$ do total do município em 1978, passou para $12,5 \%$ do total da área do município. Já a classe de uso da terra florestas, não teve uma alteração tão expressiva comparada às demais classes destacadas, isto significa dizer, que esta classe representava um total de $38,8 \%$ do espaço geográfico do município em 1978, retraindo o seu uso para $28,1 \%$ da área total.

Por outro lado, a classe de uso da terra área urbana, praticamente dobrou de tamanho no ano de 1997 em relação ao ano de 1978, alcançando 176,00 ha, ou seja, $0,9 \%$ da área total do município. Acredita-se que esse aumento deve-se, principalmente, ao abandono da atividade agrícola, procurando novos espaços na cidade, na busca de uma melhor qualidade de vida, a qual nem sempre é alcançada.

Para melhor conhecer a realidade do município e perceber se houve significativas mudanças com relação aos diferentes usos da terra, efetuou-se o mapeamento do uso da terra no ano de 2007. Para tal, foi utilizada uma imagem de satélite CBERS, de janeiro de 2007, onde constatou-se o seguinte:

Com relação às classes de uso da terra, neste mapeamento não registrouse a classe de uso não classificada, uma vez que não registrada a presença de nuvens ou manchas numa escala passível de ser quantificada, porém, uma nova classe de uso foi determinada, denominada água, com valores pouco expressivos, mas quantificáveis.

Nesta classificação foi constatado que o uso da terra culturas teve uma pequena queda em relação ao ano de 1997, ocupando uma área total de 9.238,73 ha, perfazendo 46,17 \% da área do Município de Iporã do Oeste.

A classe de uso da terra campos, também apresentou uma pequena queda em relação ao ano de 1997, abrangendo um total de 1.841,80 ha, ou 9,20\% da área do município.

A classe de uso da terra florestas apresentou uma ampliação em seu uso em relação ao mapeamento de 1997, ocupando uma área de 8.729,38 ha, ou seja, $43,63 \%$ do total. Esse aumento significativo em relação ao ano de 1997, deve-se pelo fato de a população estar se conscientizando cada vez mais em relação às questões ambientais e a conservação dos recursos naturais, sem falar da atuação efetiva dos órgãos ambientais junto a população na tarefa de reorientação sobre a conservação e preservação dos recursos naturais entre eles as florestas. 
Ao visualizar a distribuição dos diferentes usos da terra na Figura 14, podese verificar que a classe de uso florestas se apresenta espacializada em todas as porções do município, de forma heterogênea.

No que se refere à classe de uso da terra área urbana, a mesma não apresentou mudanças, ocupando um total de 192,94 ha, perfazendo 0,97\% da área do município. E com relação à classe de uso da terra água (açudes, cursos d'água), esta apresentou um total de 6,77 ha, ou 0,03\%.

$\mathrm{Na}$ Tabela 04, pode-se observar e analisar melhor sobre os diferentes usos da terra dos anos de 1978, 1997 e 2007 em uma dinâmica espaço-tempo.

Tabela 04 - Classe de uso da terra do Município de Iporã do Oeste, nos períodos de 1978, 1997 e 2007.

\begin{tabular}{llllllr}
\hline & \multicolumn{2}{c}{1978} & \multicolumn{2}{c}{1997} & \multicolumn{2}{c}{2007} \\
\cline { 2 - 7 } Classes de uso & Área (ha) & \multicolumn{1}{c}{$\%$} & \multicolumn{1}{c}{ Área (ha) } & \multicolumn{1}{c}{ Área (ha) } & $\%$ \\
\hline Culturas & $4.564,57$ & 22,8 & $1.1672,33$ & 58,3 & $9.238,73$ & 46,17 \\
Campos & $7.472,76$ & 37,3 & $2.505,77$ & 12,5 & $1.841,80$ & 9,20 \\
Florestas & $7.767,59$ & 38,8 & $5.625,43$ & 28,1 & $8.729,38$ & 43,63 \\
Área Urbana & 75,92 & 0,5 & 176,00 & 0,9 & 192,94 & 0,97 \\
Não Classificado & $1.28,78$ & 0,6 & 30,09 & 0,2 & - & - \\
Água & - & - & - & - & 6,77 & 0,03 \\
\hline TOTAL & $20.009,62$ & 100 & $20.009,62$ & 100 & $20.009,62$ & 100 \\
\hline
\end{tabular}

Organização: Rosangela L. Spironello, Jan/2007.

A partir destes dados pode-se chegar a algumas considerações a respeito da dinâmica socioeconômica e espacial do município, uma vez, que isso acaba refletindo no espaço por meio do diferentes usos da terra. Atualmente, a quantidade expressiva de florestas (43,63\%) não é somente o reflexo da aplicação das normas ambientais ou da conscientização da população em relação aos recursos naturais. Isto se deve também, em função da reordenação da estrutura fundiária e a instabilidade do sistema de produção. Ocorre também que, nos últimos anos, face a falta de políticas públicas voltadas ao setor agrícola, muitos agricultores se descapitalizaram, ficando a margem da dinâmica econômica, a qual move o sistema de produção no mercado.

Diante desta característica, os agricultores que mantém uma propriedade dentro da estrutura exigida pelo mercado, com certa diversidade na produção, com modernas tecnologias e atualização, permanecem inseridos no sistema. Já os agricultores sem incentivo e suporte de capital de giro em nas suas propriedades, 


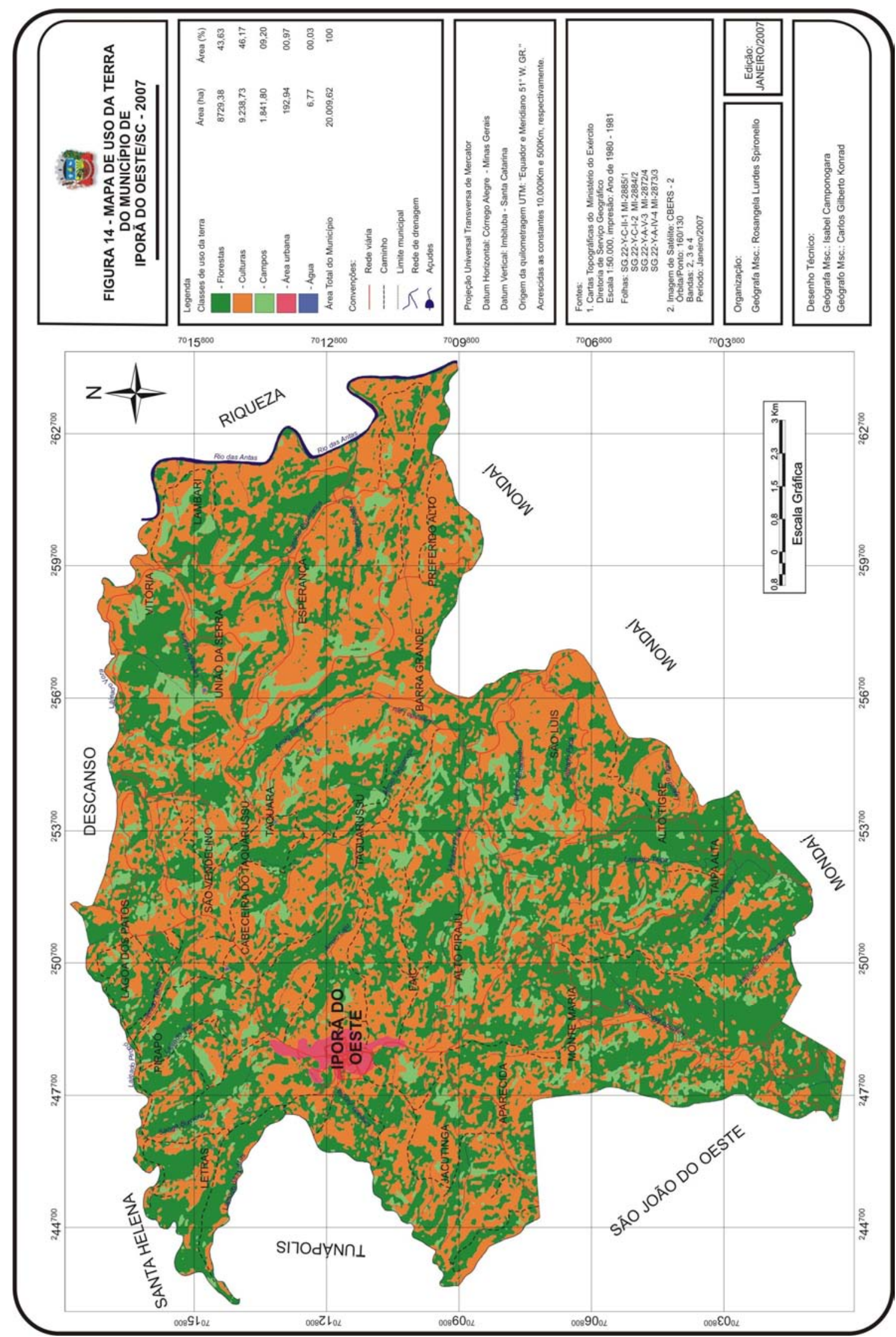


sem preparação e atualização, automaticamente vêm-se excluídos do sistema de produção, restando na maioria das vezes, a opção de vender sua propriedade ao vizinho, que possui maiores condições financeiras, ou até mesmo abandonar tal propriedade e buscar na periferia das cidades um meio para a sua sobrevivência.

A questão da estrutura familiar passa a ser um fato que também reflete nesta nova estruturação da paisagem local. Ocorre que hoje as famílias possuem um número reduzido de filhos, os quais, na maioria, encontram-se fora do município estudando, restando na propriedade somente os pais, que muitas vezes, já são aposentados e não desenvolvem mais suas atividades de forma tão ativa, ficando somente com a produção de alguns produtos agrícolas para a subsistência, e com algumas cabeças de gado. De todo modo, tais questões serão foco de nossa discussão, de forma mais aprofundada, quando abordada a complexidade de relações existentes em cada microbacia nas suas particularidades.

Em relação à reflexão feita, e para contribuir com as análises e discussões a respeito dos diferentes usos da terra, Spironello (2002), elaborou o mapa clinográfico, que no contexto do planejamento nos permite, conforme destaca Santos (2004, p.83), “...inferir informações como formas da paisagem, erosão, potencialidades para uso agrícola, restrições para ocupação urbana, manejos e práticas conservacionistas".

Assim, o mapa clinográfico foi elaborado por Spironello (2002), com base na metodologia de De Biasi (1992), identificando as seguintes classes de declividade, conforme mostra a Tabela 04.

De acordo com os dados apresentados pela Tabela 05, constata-se que a classe de declividade < 5\%, ocupa $9,7 \%$ do total da área do município, ou $1.938,53$ ha. Percebe-se com isso, que o Município de Iporã do Oeste dispõe de uma área relativamente pequena para o uso e ocupação do espaço sem restrições. Esta classe ocupa áreas formadas pelos fundos de vales, dos Arroios Macucozinho, Taipa, Taquarussu e Esperança, bem como, algumas áreas localizadas nas comunidades de Lagoa dos Patos, São Lourenço e adjacências à área urbana de Iporã do Oeste (SPIRONELLO, 2002). 
Tabela 05 - Classes de declividade do Município de Iporã do Oeste-SC.

\begin{tabular}{lcc}
\hline Classes (\%) & Área (ha) & $\%$ \\
\hline$<5$ & $1.938,53$ & 9,7 \\
$5-12$ & $2.630,46$ & 13,1 \\
$12-30$ & $4.851,82$ & 24,3 \\
$30-47$ & $7.521,93$ & 37,6 \\
$>47$ & $3.066,88$ & 15,3 \\
\hline TOTAL & $20.009,62$ & 100
\end{tabular}

Organização: Rosangela L. Spironello, Jan/06.

Fonte: Spironello, (2002, p. 70).

A classe de declividade de $5-12 \%$, ocupa um total de $2.630,46$ ha, ou seja, $13,1 \%$ da área total do município. Esta classe de declividade se distribui, na sua maioria, na porção oeste, tendendo a noroeste do município. Percebe-se a presença desta classe em menores proporções na porção leste, próximo a divisa com o Município de Riqueza, ao longo do Rio Antas. De acordo com a metodologia de De Biasi (1992), esta classe de declividade apresenta algumas restrições quanto a utilização de maquinário e irrigação.

$\mathrm{Na}$ classe de declividade de $12-30 \%$ tem-se um total de $4.851,82$ ha, ou 24,3\% da área do município, encontrando-se espacialmente bem distribuída. Conforme De Biasi (1992), nesta classe de declividade, constitui-se o limite máximo para a urbanização sem restrições.

Já a classe de declividade de 30-47\%, ocupa uma área de 7.521,93 ha, perfazendo um total de $37,6 \%$ do município. Esta classe de declividade encontra-se distribuída por todas as porções do espaço analisado e ocupa a maior área em hectares, sendo observada com maior expressividade na porção centro sul, sudeste, nordeste e norte do município, contornando os arroios e lajeados, bem como as estradas secundárias do interior do referido município Spironello (2002, p. 72). De Biasi (1992), deixa claro que, esta classe de declividade fixa o limite máximo para o corte raso, sendo que a partir do qual a exploração só será permitida se sustentada por cobertura florestal. A Figura 15 mostra a espacialização das classes de declividade no Município de Iporã do Oeste-SC. 


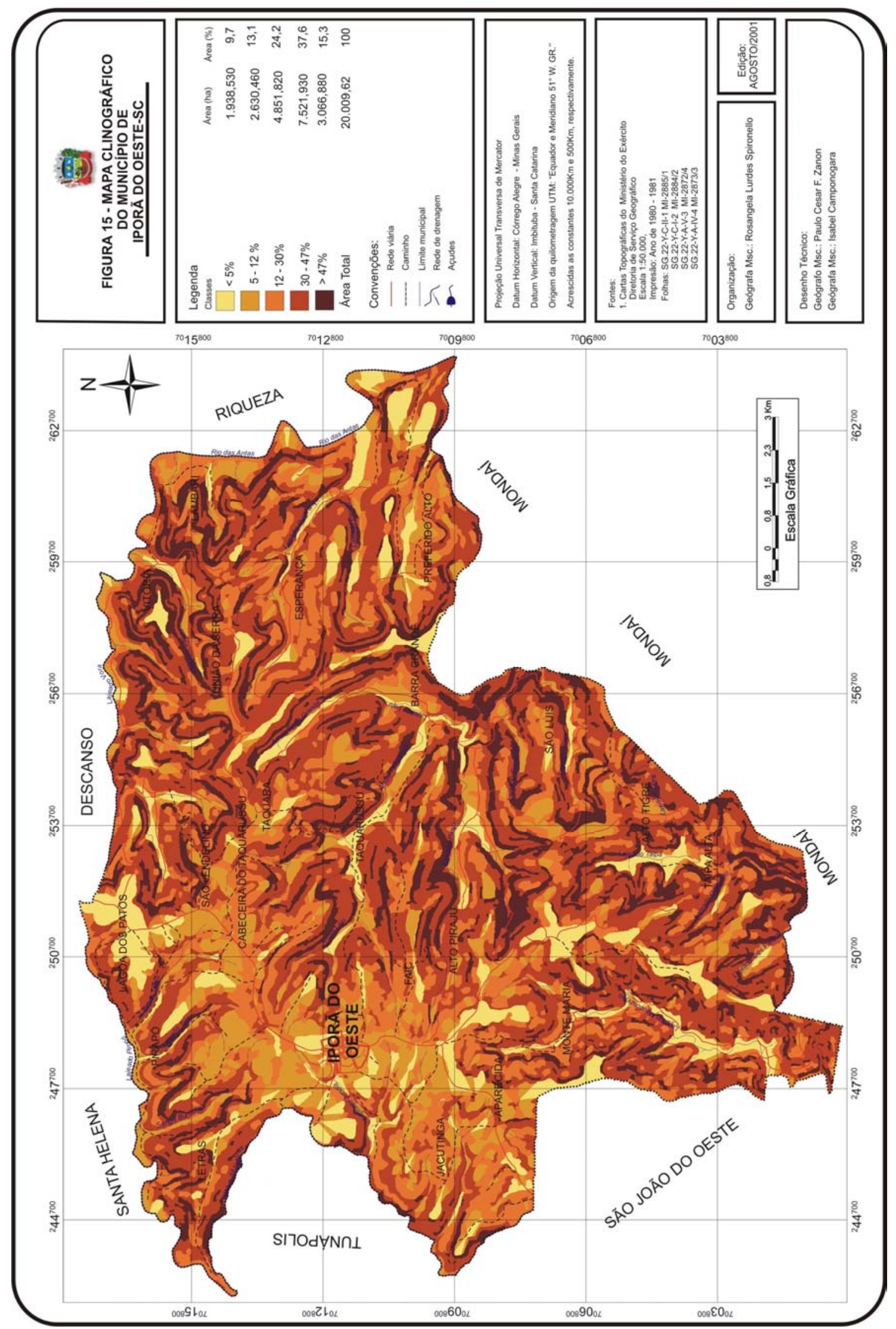


Por fim, a classe de declividade > de 47\%, ocupa um total de 3.066,88 ha, ou seja, 15,3\% da área do município de Iporã do Oeste. Esta classe de declividade tem maior expressividade nas porções sul do município, próximo à comunidade da Taipa Alta, a sudeste, ao longo dos cursos d' água dos Lajeados Paca, Enganador, Timbó e demais afluentes dos arroios Taquarussu e Barra Grande. Esta classe também se encontra próximo à comunidade de Vitória e Lambari. Conforme De Biasi (1992), nesta classe de declividade, de acordo com o Código Florestal, é proibida a derrubada de florestas, sendo tolerada a extração de toros quando em regime de utilização racional, que vise a rendimentos permanentes.

Com base no mapa clinográfico tem-se um reflexo de como se configura a topografia no Município de Iporã do Oeste. A partir destas considerações, conclui-se que o referido município possui sua área distribuída em mais de 50\% nas declividades acima a 30\%, ou seja, em áreas de conservação e preservação permanente, o que implica em "repensar" o espaço geográfico, adequando a sua utilização de forma racional, buscando no planejamento o suporte para tal.

\section{2 - ZONEAMENTO-ANTRÓPICO-AMBIENTAL DAS MICROBACIAS HIDROGRÁFICAS DO MUNICÍPIO DE IPORÃ DO OESTE-SC}

Para a análise espacial dos fatores socioeconômicos e ambientais do Município de Iporã do Oeste, optou-se trabalhar com duas microbacias delimitadas a partir do Projeto Microbacias II, implantado em 2002, tendo como órgão responsável a Epagri. O ZAA foi pensado a partir das peculiaridades de cada microbacia selecionada.

Assim sendo, o Município de Iporã do Oeste apresenta um total de nove microbacias delimitadas (das quais, seis fazem parte do referido projeto), sendo: Microbacias hidrográficas do Lajeado Macucozinho I e II (MHLMI) e (MHLMII), Arroio Taipa (MHAT), Arroio Taquarussu (MHATA), Lajeado Esperança (MHLE), Lajeado Vorá (MHLV), Lajeado Pirapó (MHLP), Lajeado Jundiá (MHLJ) e Lajeado Lajú (MHLL). Na Figura 16, pode-se observar a delimitação das microbacias no Município de Iporã do Oeste-SC. 


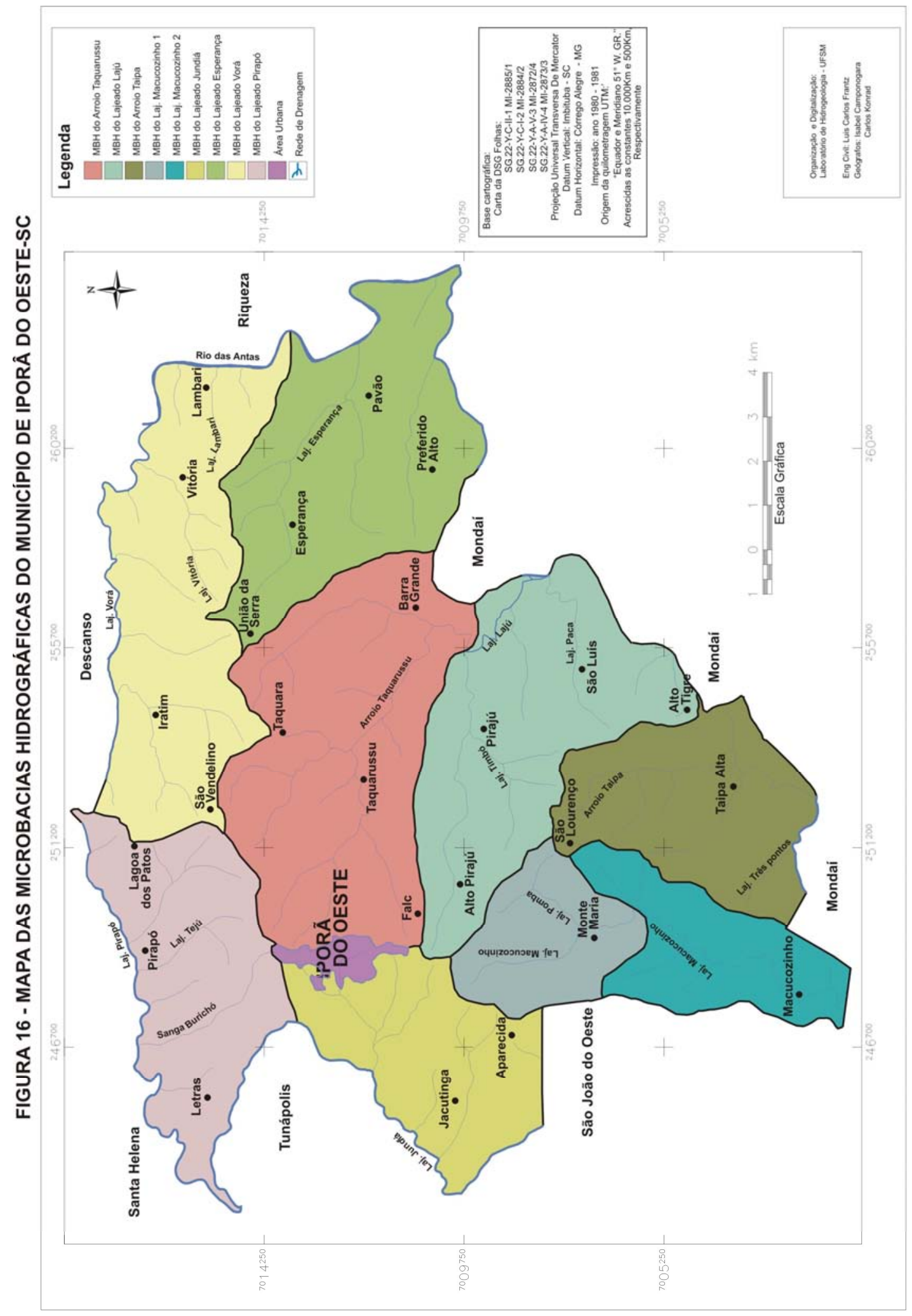


Para selecionar as duas microbacias, objeto de estudo na referida pesquisa, levou-se em consideração as características físicas, socioculturais, econômicas e ambientais existentes em cada espaço delimitado. Assim, foram selecionadas a MHLP e MHLE.

A microbacia hidrográfica do Lajeado Pirapó foi selecionada por ser uma microbacia que exerce uma função importante e direta, não só com a população que se encontra inserida na área de estudo, mas com a população urbana como um todo. É desta microbacia que a população da área urbana é abastecida. A subestação de tratamento da CASAN (Companhia Catarinense de Águas e Saneamento) fica localizada no médio curso do referido Lajeado. Preocupados com a qualidade e a manutenção dos recursos naturais e em especial dos recursos hídricos, esta microbacia foi selecionada para a pesquisa.

Outro ponto importante a considerar é a realidade topográfica da microbacia. A mesma apresenta nos dados, em torno de $58 \%$ do total de sua área com declividades de $<5 \%$ até $30 \%$, o que nos permite crer que é possível utilizar o espaço com mais liberdade, porém, respeitando seus limites de acordo com a legislação. O fator étnico também foi levado em consideração, pois nesta microbacia predominam a população de origem alemã e as características culturais encontram claramente registradas na paisagem, através das construções, organização das propriedades, entre outras.

Já a microbacia do hidrográfica Lajeado Esperança apresenta uma realidade física de seu relevo um pouco diferenciada em relação a microbacia do Lajeado Pirapó. Outro fator é que não apresenta população concentrada na área urbana, ou seja, é uma microbacia localizada na sua totalidade, no interior do município, estando totalmente delimitada dentro da unidade administrativa de Iporã do Oeste-SC. Esta microbacia também foi selecionada por ter instalado, em seu interior, a única escola núcleo do município, a qual absorve a maioria dos estudantes que residem no interior do município (ensino de educação infantil até a $8^{\text {a }}$ série do ensino fundamental). Nesta microbacia tem-se a predominância da população de origem italiana, a qual tem mostrado nas características de uso e ocupação do espaço no decorrer do tempo uma apropriação maior em relação aos de origem alemã, da outra porção do município. 


\subsection{1 - Aspectos socioeconômicos e ambientais das Microbacias dos Lajeados Pirapó (MLP) e Esperança (MLE)}

No que se refere ao conjunto de informações relacionadas à microbacia hidrográfica do Lajeado Pirapó, pode-se dizer que a mesma é composta por 130 famílias, distribuídas entre as comunidades de: Linha Letras, Linha Pirapó, Linha Lagoa dos Patos, Linha Cabeceira Taquarussú.

Destas famílias, 46 são produtores classificados como de estrutura consolidada, 38 de transição 1, 31 produtores de transição 2, e periféricos num total de 15.

Os agricultores que apresentam uma estrutura consolidada são os que possuem uma renda superior a 3 salários mínimos por pessoa ocupada, e que a produtividade resulte numa quantidade acima das médias da região. Nesta categoria se enquadram os sistemas de produção que visam à exploração e a criação de aves e suínos, bem como, culturas voltadas para a alimentação de animais e ao abastecimento de agroindústrias de fumo e soja. Vale destacar também que nesse tipo de estrutura aplica-se na agricultura uma mão de obra familiar, ou seja, mais de $50 \%$ deve ser de origem familiar e no mínimo de $70 \%$ do valor bruto de produção deve ser vendido. Molinari (2003). http://www.microbacias.sc.gov.br . Acesso em 18 de agosto de 2007.

Conforme descreve Molinari (2003), os agricultores classificados como de transição 1 e 2 , são produtores que possuem pequenas áreas, onde a produtividade se aproxima da média regional. A média salarial gira em torno de 1 a 3 salários mínimos por mês. A mão de obra é predominantemente familiar. Destaca-se que nessa estrutura, o uso de capital é baixo, ou seja, os maquinários existentes para as atividades agrícolas, são na maioria de tração animal. A venda dos produtos é feita em pequena escala, agregando assim, pouca renda às pessoas ocupadas.

Outra característica das famílias, que se inserem na estrutura geral, são as dos agricultores periféricos. Estes são produtores que apresentam uma produtividade abaixo da média regional. Normalmente o que se produz é consumido na própria propriedade, ou seja, a produção é para a subsistência. A média salarial é de menos de um salário por mês, por pessoa ocupada. A mão-de-obra é toda familiar. Não são agregados valores a produção primária, justamente por estarem concentrados em pequenas áreas, utilizando-se de pouca tecnologia (maquinários) 
para as atividades agrícolas. Normalmente vendem sua força de trabalho para agricultores que possuem sua estrutura consolidada. Esse tipo de agricultor raramente participa de entidades associativas como cooperativas. Molinari (2003). http://www.microbacias.sc.gov.br . Acesso em 18 de agosto de 2007.

Percebe-se que na microbacia hidrográfica do Lajeado Pirapó ocorre a presença de uma quantidade significativa de produtores consolidados, porém os caracterizados de transição têm um número expressivo. Essa estatística nos mostra que há a necessidade de se buscar alternativas para a diversificação da produção nesse espaço, inclusive, inserir no mercado os que estão à margem do sistema, que é excludente.

Apesar de algumas carências, deve-se destacar que na microbacia são desenvolvidas inúmeras atividades voltadas ao setor agropecuário, dentre elas pode-se citar: a produção de milho, feijão, soja, fumo, criação de suínos, gado de leite e de corte, avicultura e produção de cítrus, conforme destaca o Plano de Desenvolvimento da Microbacia Hidrográfica Lajeado Pirapó (2005). Na Figura 17 pôde-se observar em uma propriedade visitada, a atividade voltada à produção de pêssego. Tal diversidade na produção possibilita aos agricultores um giro maior de capital na propriedade, podendo ser bem gerenciada e/ou orientada, no sentido de ganhar mercado e agregar valor ao produto local.

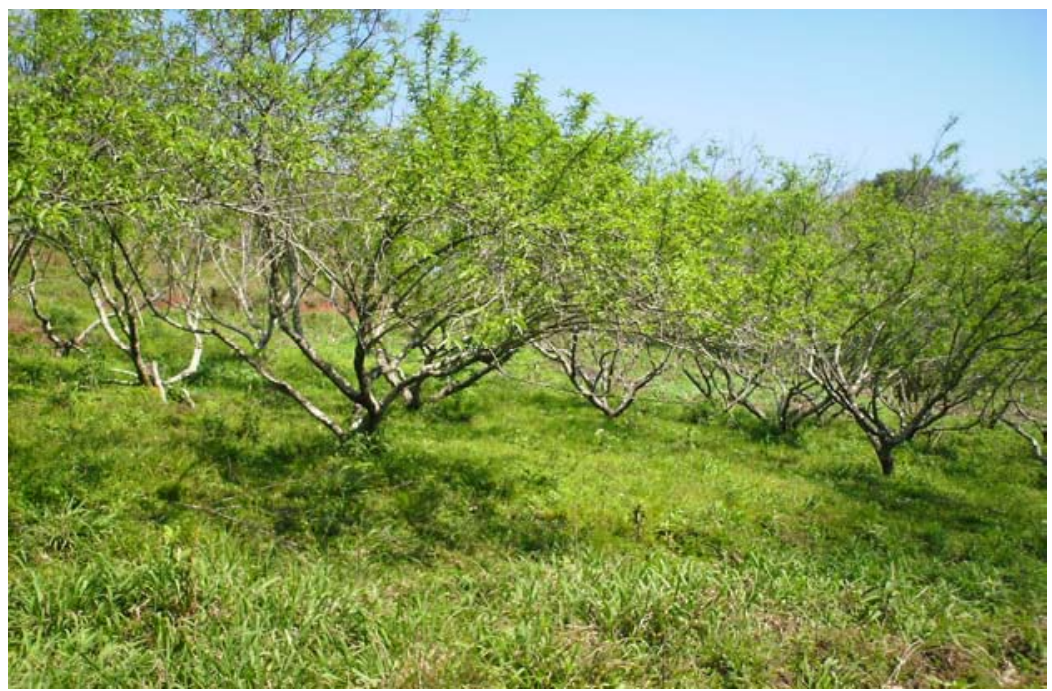

Figura 17 - Produção de pêssego na microbacia do Lajeado Pirapó, Iporã do Oeste-SC. Organização: Rosangela L. Spironello, Ago/2007.

Fonte: Rosangela L. Spironello, Ago/2007.

De acordo com os dados do Plano de Desenvolvimento da Microbacia Hidrográfica Lajeado Pirapó (2005), a população inserida na microbacia hidrográfica 
do Lajeado Pirapó elencou inúmeras potencialidades existentes no interior da microbacia, considerando os aspectos ambientais, sociais e econômicos, como: produtos orgânicos, recolhimento de embalagens de agrotóxicos, recuperação dos solos, produção de grãos, área industrial, gado de leite, agroindústria, suinocultura, fumo, plantio direto, meios de transporte, saúde, boa convivência, simplicidade, amizade, estrutura comunitária satisfatória, clube de mães e idosos, lazer, amizade, campo de futebol, entre outros.

Percebe-se que alguma iniciativa voltada à qualidade dos produtos e do ambiente se faz presente na área de estudo, o que nos permite dizer que é possível promover mudanças que visem à melhoria da saúde e do bem estar da população e do meio ambiente como um todo, pois as pessoas mostram-se abertas para tal, e por ser ainda uma necessidade nos dias atuais, face às alterações que espaço vem sofrendo em função da apropriação dos recursos naturais.

Assim, a população envolvida na microbacia também levantou algumas prioridades a serem discutidas e analisadas, buscando melhoramento na condição socioeconômica e ambiental. Dos dados levantados no Plano de Desenvolvimento da Microbacia Hidrográfica Lajeado Pirapó (2005), tem-se como priorização temas voltados a questão ambiental, pois os mesmos destacaram que o uso de agrotóxicos é um dos principais aspectos que compromete a qualidade ambiental naquele espaço, seguido pela carência de água, o que se faz sentir principalmente em períodos de estiagem. Isso também encontra-se atrelado a outros aspectos como poluição em geral (causada principalmente pelos dejetos de suínos e humanos), que ao se somarem ampliam e tornam mais complexos os problema ambientais locais, como é o caso das nascentes desprotegidas e a falta de mata ciliar ao longo dos lajeados, que se localizam na microbacia.

Ainda com relação às informações obtidas do Plano de Desenvolvimento da Microbacia Hidrográfica Lajeado Pirapó (2005), com relação à priorização no setor social, deve-se voltar à atenção para: as doenças, a inveja ${ }^{7}$, ganância e desconfiança, entre outros. Numa sociedade capitalista, onde se busca a satisfação e o bem estar pessoal, tais questões infelizmente fazem parte deste cenário, dificultando o convívio e a troca de experiências entre as pessoas.

\footnotetext{
${ }^{7}$ Característica bem presente nos dias atuais e em todos os segmentos da sociedade, desde os pequenos aos grandes grupos. Esta por sua vez vem acompanhada pela ganância e individualismo, distanciando ainda mais os seres humanos de um convívio social harmonioso.
} 
No que se refere aos temas de priorização no setor econômico, foram levantadas algumas questões, sendo as principais: a falta de recursos e a exploração de insumos agrícolas. A falta recursos é a que se faz mais presente dentro das propriedades que fazem parte da microbacia, uma vez que as políticas agrícolas não atendem a demanda e a realidade local e regional, o que impede que a população possa investir e planejar suas atividades para um período mais longo, ou até mesmo garantir a produção voltada ao mercado consumidor.

Outro item levantado foi relativo à exploração de insumos agrícolas, pois os preços chegam ao produtor num valor alto, impossibilitando o mesmo de adquiri-los para garantir uma produção com mais qualidade e rendimento.

Por outro lado, os agricultores que encontram-se inseridos na área de estudo destacaram que apesar dos problemas existentes na microbacia e das prioridades que deverão ser analisadas e discutidas, tem-se as oportunidades, dentre elas o próprio projeto microbacias o qual apresenta condições de discutir e planejar o espaço local levando em consideração a realidade da população. Também destacaram o acesso à assistência técnica (na área de produção de leite, agrícola), transporte escolar (possibilitando o acesso à escola de todos os alunos sem custos para as famílias), área industrial (com a fabricação de móveis), entre outras. Isso contribui para a melhoria nas condições de vida da população, a partir das informações buscadas e aproveitadas em cada setor, sem falar na promoção do desenvolvimento local.

Entre todas estas condições, o que pôde-se perceber pelos dados fornecidos pela Epagri, no Plano de Desenvolvimento da Microbacia Hidrográfica Lajeado Pirapó (2005), e em conversa informal com os agricultores, que existe um desejo da população em permanecer no campo, pelo fato de que gostam da profissão que exercem e se sentem felizes com o que fazem. Bastaria que as políticas agrícolas fossem melhor estudadas e aplicadas, promovendo ainda mais o desenvolvimento e a qualidade de vida dessa população.

Já a microbacia hidrográfica do Lajeado Esperança, possui um total de 119 famílias, as quais distribuem-se entre as comunidades de União da Serra, Linha Esperança, Linha Pavão, e Linha Preferido Alto. Esta microbacia apresenta uma realidade um pouco diferente da microbacia hidrográfica do Lajeado Pirapó, pelo menos no que diz respeito à classificação dos produtores e a condição topográfica. 
Ocorre que das 119 famílias envolvidas na área de estudo, 73 produtores encontram-se na classe de transição 1 e 2. Apenas 25 famílias apresentam uma estrutura consolidada e 21 estão inseridas na classe de produtores periféricos. Considerando as definições estabelecidas a cada classe dentro das microbacias, tem-se nesta área de estudo um reflexo da situação da maioria das pequenas propriedades na região, de acordo com as informações contidas no Plano de Desenvolvimento da Microbacia Hidrográfica do Lajeado Esperança (2005). Verificou-se ainda, que existe uma acentuada diferença na configuração e estrutura das propriedades da microbacia hidrográfica do Lajeado Pirapó em relação ao Lajeado Esperança.

Nesta microbacia, os problemas se mostram de forma mais visíveis, além de contarem com a falta de incentivo, políticas agrícolas, planejamento, entre outros. Estes fatores são apenas alguns que provocam a desestruturação das propriedades, por exemplo, abrindo precedentes para um possível abandono das mesmas.

Apesar das condições, na maioria das vezes, não serem favoráveis ao permanecimento do agricultor no campo, os mesmos se sentem felizes com a profissão e fazem o possível para permanecerem no espaço no qual podem plantar e colher seus produtos, criando assim, laços harmoniosos com o meio em que vivem. Plano de Desenvolvimento da Microbacia Hidrográfica do Lajeado Esperança (2005).

Constatou-se a partir dos dados do relatório fornecido, que a maioria da população não vê boas perspectivas com relação ao meio ambiente, face as próprias condições em que os mesmos estão condicionados.

Um dos fatos que não é novidade para a realidade que se vivencia é que a maioria dos questionados não acreditam ser possível trabalhar sem o uso de agrotóxicos. Isto é um reflexo da comodidade e da falta de conscientização em relação à saúde de cada um. Pois se sabe que o uso intensivo de agrotóxicos pode causar doenças graves, sem falar da contaminação do solo, alimentos e recursos hídricos.

Apesar de encontrarem-se em todos os espaços geográficos, desde a escala local até a global, limitações e potencialidades, o que pôde-se perceber na área de estudo é que a população tem classificado como potencialidade, as atividades voltadas a avicultura, gado de leite, reflorestamento, pastagens, plantio direto, produção de alimentos, grãos e suinocultura. Destacam também a 
importância dos trabalhos (individual e em grupo), a participação, a amizade, entre outros, como pontos relevantes e potenciais para a manutenção do homem no campo, Plano de Desenvolvimento da Microbacia Hidrográfica do Lajeado Esperança (2005)

Da mesma forma, como o trabalho desenvolvido na microbacia do Lajeado Pirapó, a população da microbacia hidrográfica do Lajeado Esperança, elencou algumas prioridades a serem discutidas e analisadas para o setor socioeconômico e ambiental.

No setor social, conforme destaca o Plano de Desenvolvimento da Microbacia Hidrográfica Lajeado Esperança (2005), as prioridades levantadas foram as seguintes: a questão das doenças é a maior preocupação que envolve a população desta área de estudo, seguidos da questão de assaltos e a falta de respeito com as pessoas. Acredita-se que estas condições estão atreladas à própria situação em que alguns agricultores encontram-se inseridos, ou seja, a falta de estrutura econômica e financeira, a comodidade na utilização de agrotóxicos, elevando os índices das doenças; são apenas alguns dos fatores que chamam a atenção sobre estas condições. Destaca-se também que a ganância e a falta de interesse são outros fatores que contribuem para a desestruturação das famílias e das comunidades envolvidas no estudo.

No que se refere à prioridade no setor econômico, conforme aborda o relatório do Plano de Desenvolvimento da Microbacia Hidrográfica do Lajeado Esperança (2005), tem-se à baixa renda e as lavouras com pouca produtividade. Essa questão mostra realmente que as propriedades, bem como os produtores, necessitam de atenção e atendimento técnico eficiente, sem falar de políticas agrícolas que possibilitem aos mesmos ampliarem suas oportunidades, fazendo com que esses produtores permaneçam no campo com o mínimo de qualidade de vida.

Quanto à prioridade voltada ao setor ambiental, a maioria dos agricultores destacou que se deve dar atenção especial às fontes de água e as nascentes, pois as mesmas encontram-se desprotegidas. Sobre esta questão, torna-se relevante salientar, que estando às fontes de água ou nascentes desprotegidas, podem agregar uma série de outras problemáticas, como: a redução do fluxo de água superficial e subterrâneo, diminuição da qualidade da mesma, aumentando assim os índices de erosão e assoreamento dos rios. Outra prioridade levantada foi sobre os agrotóxicos, os quais são utilizados pela maioria dos agricultores, causando a 
contaminação dos solos, lençol freático, sem falar dos danos causados à saúde, conforme já destacado anteriormente.

Diante de tais prioridades que devem ser pensadas e analisadas com total atenção (pois delas poderão emergir ações que promovam o desenvolvimento e a qualidade de vida e ambiental desse espaço), não poder-se-ia deixar de destacar que existem oportunidades também neste meio, ao qual a população encontra-se inserida. Uma das oportunidades é a presença da Escola Nuclearizada de Educação Básica Municipal, a qual busca através da educação, envolver o aluno na realidade local e regional, contando com uma grade curricular de disciplinas básicas e voltadas ao setor agropecuário. O transporte escolar, assistência técnica e o próprio projeto microbacias são excelentes oportunidades para a busca de uma estruturação melhor dos produtores no meio rural.

Vê-se que em ambas microbacias, algumas potencialidades e limitações não se diferem pelo conjunto de ações que são empreendidas no espaço pelo homem. Mas o que se pode concluir a priori, é que a microbacia hidrográfica do Lajeado Esperança em função de vários aspectos contidos na sua estrutura geral, apresenta um conjunto maior de problemas socioambientais, os quais necessitam ser pensados e analisados, possibilitando a inserção de parte da população (que está fora do sistema) na dinâmica de mercado, aumentando assim, a sua autoestima e melhorando as suas condições de permanência no campo.

\subsection{2 - Mapeamento do uso da terra e de declividades das microbacias hidrográficas dos Lajeados Pirapó e Esperança.}

Para contribuir com o aprofundamento dos estudos sobre a realidade das microbacias, e para elaborar o Zoneamento-Antrópico-Ambiental, efetuou-se inicialmente, o mapeamento do uso da terra, a partir da imagem de satélite CBERS II, bandas 2, 3, e 4, datada de Janeiro de 2007. Objetivando conhecer melhor as características econômicas e sociais das microbacias, inicialmente elencou-se as classes de uso da terra, que para a referida pesquisa foram definidas as seguintes: florestas, campos, área urbana, culturas e água.

Assim, o referido mapeamento realizado na microbacia hidrográfica do Lajeado Pirapó nos mostrou que a microbacia possui uma área total de 2.176,09, da 
qual, 782,25 ha ou $35,95 \%$ é ocupada pelo uso da terra culturas, uma parte considerável comparando-se a outras classes de uso, e se encontra distribuída de forma homogênea em todas as porções da microbacia. Nesta classe pode-se destacar a presença de milho e fumo principalmente, seguido pelas culturas de subsistência como o feijão e a mandioca.

Em seguida, tem-se a classe de uso da terra florestas, que ocupa um total de $1.217,14$ ha, ou seja, 55,93\% da microbacia, uma porcentagem importante pela função que esta classe assume no contexto de preservação e conservação dos recursos naturais, em especial dos recursos hídricos. Percebe-se que esta classe encontra-se distribuída principalmente nas áreas de encostas e em algumas das margens, direita e esquerda dos cursos d' água deste Lajeado. Face ao mapeamento que se tem feito no território do Município de Iporã do Oeste, esta porção da microbacia (encosta dos morros em especial), não tem mostrado significativas alterações desde os mapeamentos anteriores datados de 1978 e 1997.

Isso é positivo, pois mostra que a população tem se preocupado com as questões ambientais no seu entorno e as áreas de florestas têm crescido de forma considerável. Essa característica foi observada também em trabalho de campo. $\mathrm{O}$ que nos chamou a atenção foi a presença quase que insignificante de espécies de reflorestamento de eucaliptos e pínus. O que vem ocorrendo conforme verificado in loco, é regeneração de espécies nativas (capoeiras e capoeirões) face ao abandono de algumas propriedades e das áreas de encostas.

A classe de uso campos aparece com pouca expressividade, ocupando um total de 173,11 ha, perfazendo 7,96\% da área total. Já a classe de uso da terra urbano e água não apresentam valores expressivos dentro da área de estudo.

Com relação aos dados levantados a partir do mapeamento do uso da terra da microbacia hidrográfica do Lajeado Esperança, pôde-se perceber que a microbacia ocupa uma área total de 2.823,85 ha, dos quais 202,48 ha, ou seja, 7,17\% são ocupados por campos e encontram-se distribuídos de forma esparsa pela área da microbacia.

A classe de uso da terra florestas ocupa um total de 871,44 ha, perfazendo um total de $30,86 \%$ da área, a qual encontra distribuída com maior proporcionalidade na porção norte-nordeste da microbacia, ou seja, na margem esquerda do curso principal do Lajedo Esperança. A Figura 18 mostra ao fundo, na margem esquerda do Lajeado Esperança, uma porção de área de florestas. Nesta 
Figura nota-se a presença de espécies, na sua maioria de (hovenia dulcis) Uva-doJapão, com alguns fragmentos de espécies nativas como Angico (Parapiptadenia rígida) e o Cedro (Cedrela fissilis). Observa-se também que na margem direita do Lajeado, praticamente não ocorre a presença de remanescentes florestais. As áreas são usadas normalmente para pastagem $\left(\right.$ potreiro $^{8}$ ), pois o gado tem acesso livre à água para a sua dessedentação, e para a agricultura, com o cultivo do milho e do fumo.

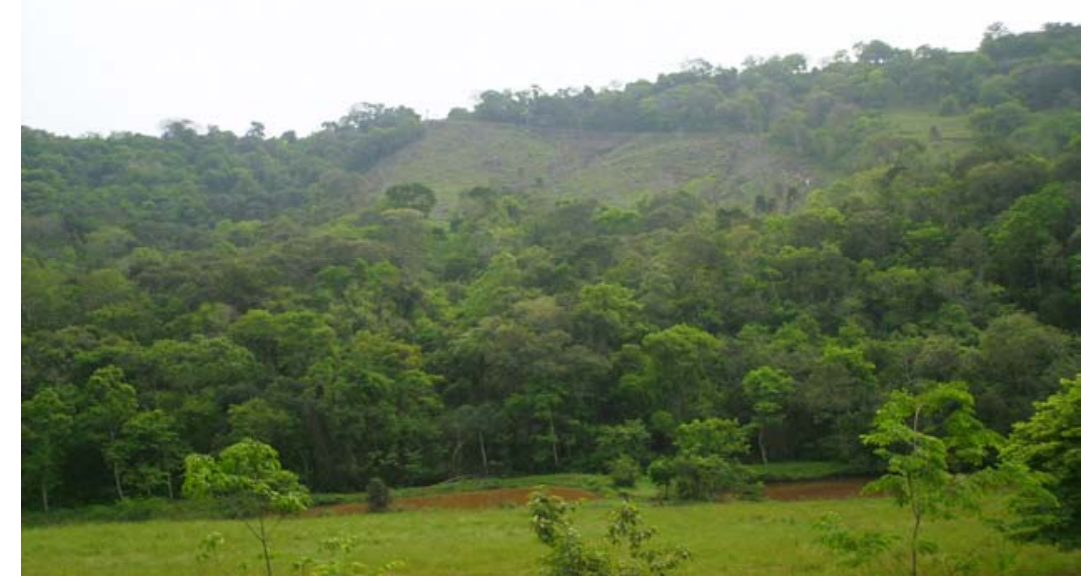

Figura 18 - Área de floresta na microbacia do Lajeado Esperança, Iporã do Oeste-SC.

Organização: Rosangela L. Spironello, Ago/2007.

Fonte: Rosangela L. Spironello, Ago/2007.

No que se refere à classe de uso da terra culturas, esta apresenta um total de $1.749,93$ ha, ou $61,96 \%$ da área da microbacia e encontra-se distribuída de forma homogênea em todas as porções da área em estudo. Nesta classe o que se percebe é a predominância da produção da cultura de milho, produto este, característico da região e em geral dentro do sistema de produção das famílias de agricultores de origem italiana.

O fumo é outra cultura que se destaca não só na microbacia, mas em todo o município. A Figura 19 (a) e (b) tem-se as culturas de milho e fumo em estágio inicial de crescimento.

\footnotetext{
${ }^{8}$ Potreiro - de acordo com o dicionário Aurélio (2005) lugar cercado, pouco extenso, nos arredores duma estância, no qual se guardam os animais empregados nos trabalho cotidianos (cavalos de montaria, vacas de leite, etc.).
} 

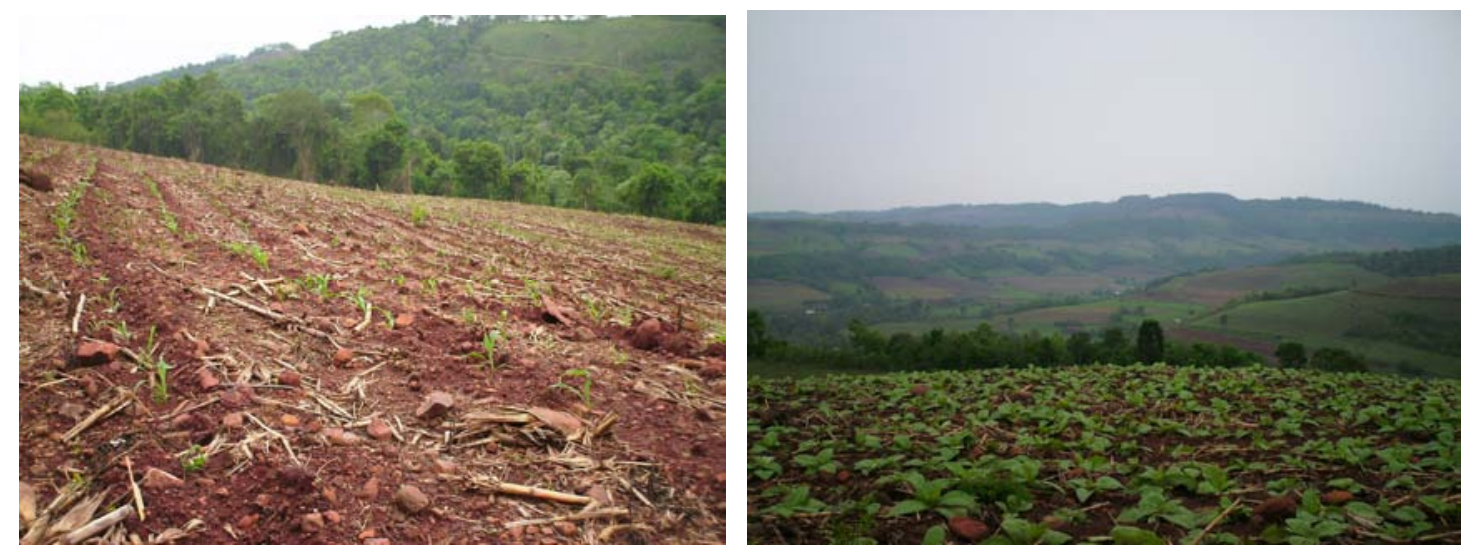

Figura 19 - (a) produção de milho Esperança.

(b) produção de fumo na microbacia do Lajeado Organização: Rosangela L. Spironello, Ago/2007.

Fonte: Rosangela L. Spironello, Ago/2007.

A classe de uso da terra água aparece com um total de 0,46 ha, ou 0,01\%. Já a classe de uso da terra urbano não foi encontrada, por ser uma microbacia delimitada na sua totalidade no interior do município. As classes de uso da terra das microbacias do Lajeado Pirapó e do Lajeado Esperança podem ser observadas na Tabela 08 e Figura 20 e 21.

Tabela 06 - Uso da terra na microbacia hidrográfica do Lajeado Pirapó, Município de Iporã do Oeste - 2007.

\begin{tabular}{ccccc}
\hline & \multicolumn{2}{c}{ MLP } & \multicolumn{2}{c}{ MLE } \\
\hline Classes & Área (ha) & $\%$ & Área (ha) & $\%$ \\
\hline Florestas & $1.217,14$ & 55,93 & 871,44 & 30,86 \\
Culturas & 782,25 & 35,95 & $1.749,47$ & 61,96 \\
Campos & 173,11 & 7,96 & 202,48 & 7,17 \\
Água & 0,30 & 0,01 & 0,46 & 0,01 \\
Urbano & 3,29 & 0,15 & 0,00 & 0,00 \\
\hline TOTAL & $2.176,09$ & 100 & $2.823,85$ & 100 \\
\hline
\end{tabular}

Organização: Rosangela L. Spironello, Mar/2007.

Comparando-se os dados da tabela, percebe-se que a classe de uso da terra campos abrange praticamente a mesma porcentagem de área ocupada em cada microbacia, porém o diferencial maior encontra-se na classe de uso da terra culturas. A microbacia do Lajeado Esperança apresenta uma área de praticamente $62 \%$ ocupada pelas atividades agrícolas voltadas à produção de milho, fumo, feijão e alguns outros produtos voltados à subsistência da população, como a mandioca, o arroz e o trigo. Vê-se que na MHLE, a apropriação do espaço se dá de forma mais acentuada. 


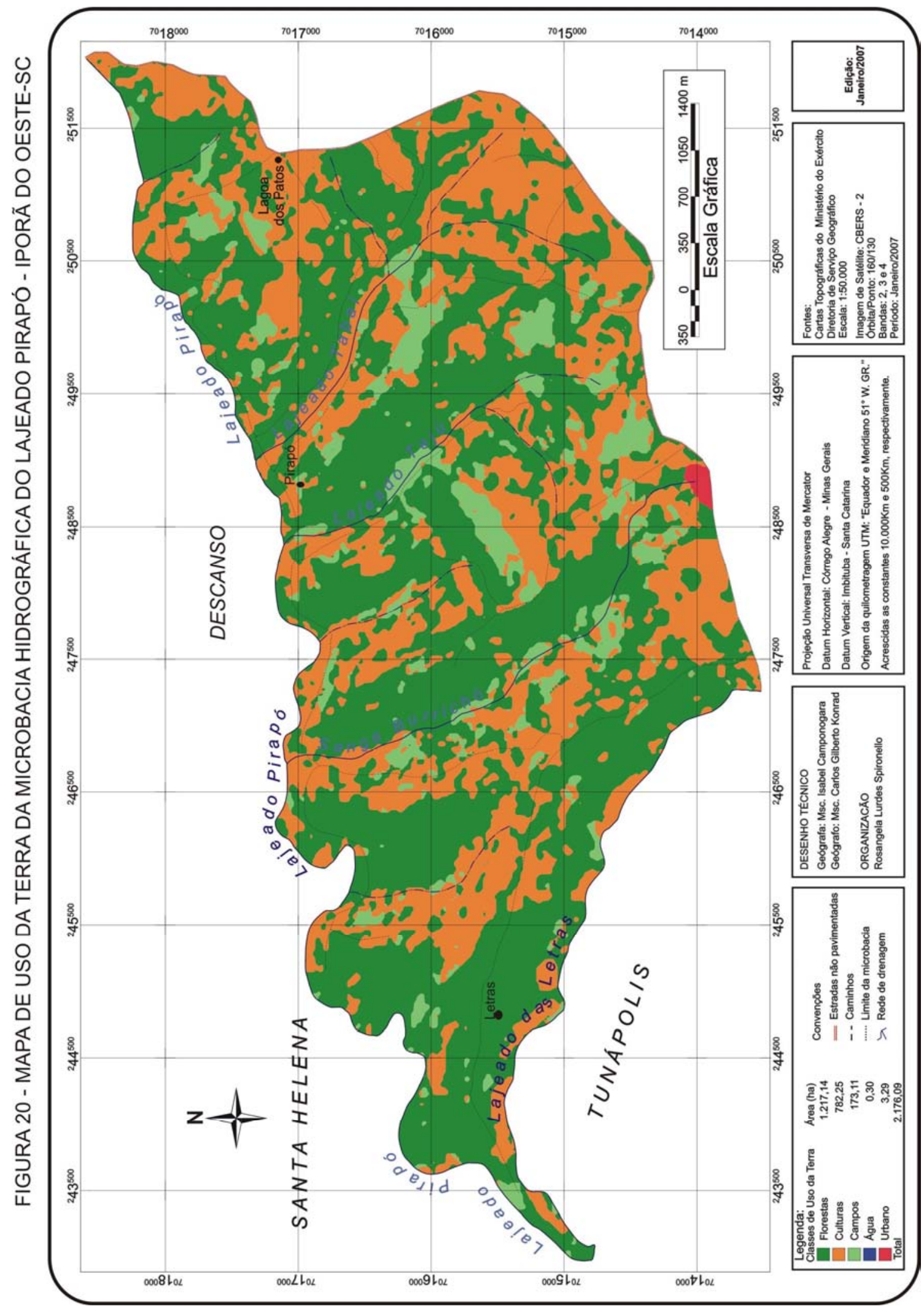




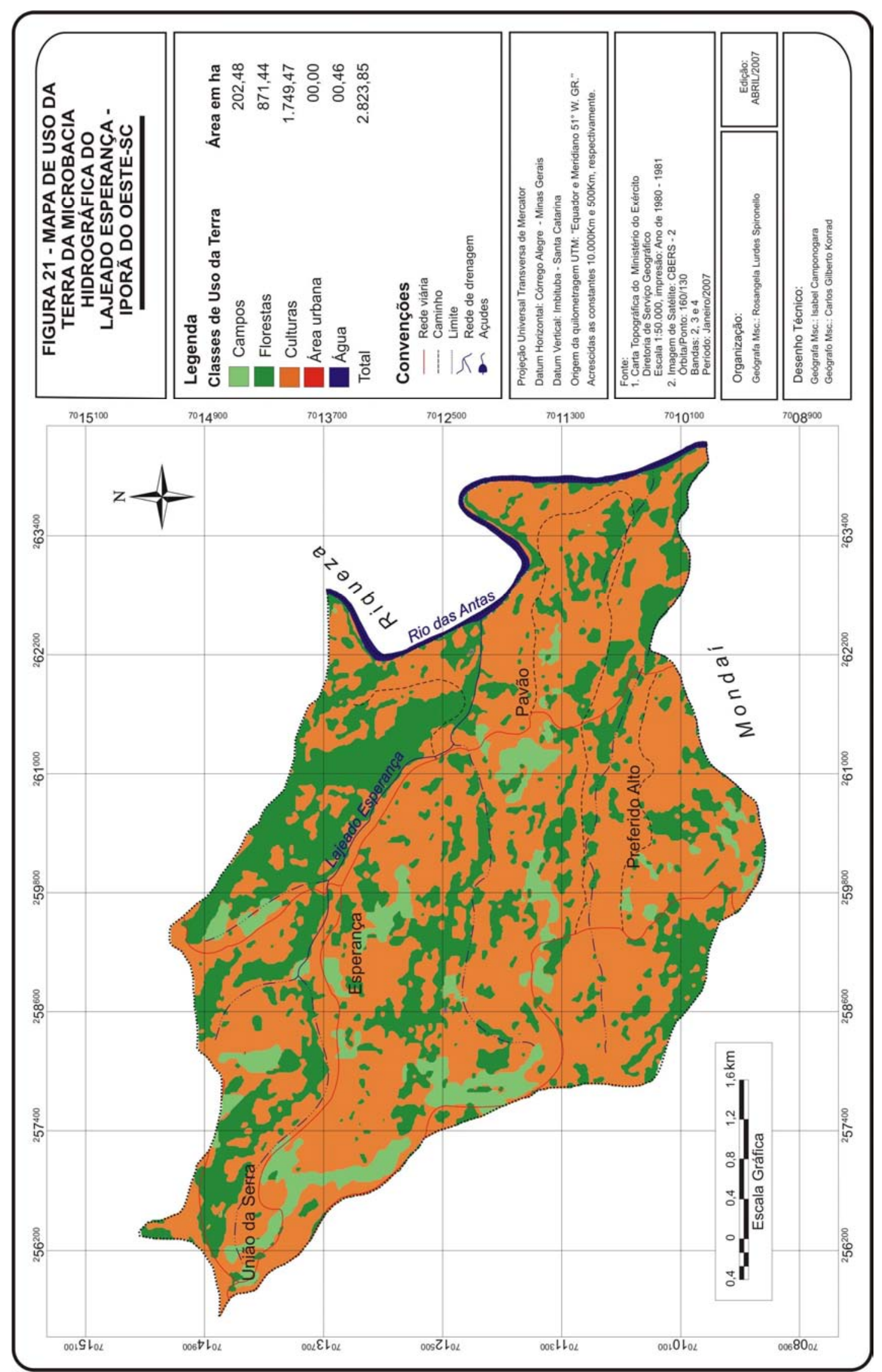


Essa característica é ainda um reflexo da forma inicial de ocupação do espaço pelas famílias, ou seja, desde o princípio da colonização, essa porção do espaço territorial do Município de Iporã do Oeste foi ocupada por descendentes de italianos, na sua maioria. Acostumados a trabalhar nos lugares onde as características topográficas não favoreciam e a necessidade de fazer a "América", impulsionou a intensificação do uso da terra. As áreas florestadas foram praticamente eliminadas no intuito de vender a madeira e formar novos espaços destinados às culturas de milho e pastagens.

O uso da terra florestas se destaca na microbacia do Lajeado Pirapó com praticamente $56 \%$ da área, em contrapartida com o Lajeado Esperança que tem uma área ocupada por florestas de apenas 30,86\%.

No que se refere às classes de declividade da microbacia do Lajeado Pirapó, pode-se dizer que dos 2.176,09 ha que compõe a área total, 258,46 ha, ou $11,87 \%$ estão inseridos na classe < de 5\%, aqui considerada como área plana, de acordo com Lepesch (2002). Nesta área é possível aplicar técnicas de manejo do solo sem muitas restrições. Esta classe encontra-se distribuída de forma mais significativa na porção leste da microbacia, próximo à comunidade de Lagoa dos Patos.

Já na classe de 5 a 12\% de declividade apresenta um total de 502,25 ha, uma área que ocupa $23,08 \%$ da microbacia. Esta classe de declividade encontra-se distribuída de forma mais representativa da porção leste a sul da microbacia.

A classe de 12 a $30 \%$ de declividade não difere praticamente em relação a anterior, nela encontra-se uma área total de 510,90 ha, ou seja, 23,48 \% do total da microbacia e encontra-se distribuída de forma heterogênea na mesma, destacandose a área próxima a foz do Lajeado, porção centro-sul e norte-leste da microbacia.

No que se refere à classe de 30 a 47\%, esta representa a maior área em hectares dentro da microbacia. Vale ressaltar que nesta classe tem-se a classificação das áreas de Conservação Permanente (ACP), conforme o Código Florestal Lei 4.771 de 1965. Essa classe ocupa uma área de 716,89 ha, abrangendo um total de $32,94 \%$ da microbacia e encontra-se distribuída de forma mais representativa na porção oeste da área de estudo, na foz do Lajeado Pirapó. Os dados relativos ao mapeamento das classes de declividade podem ser visualizados na Tabela 07 e Figura 22. 


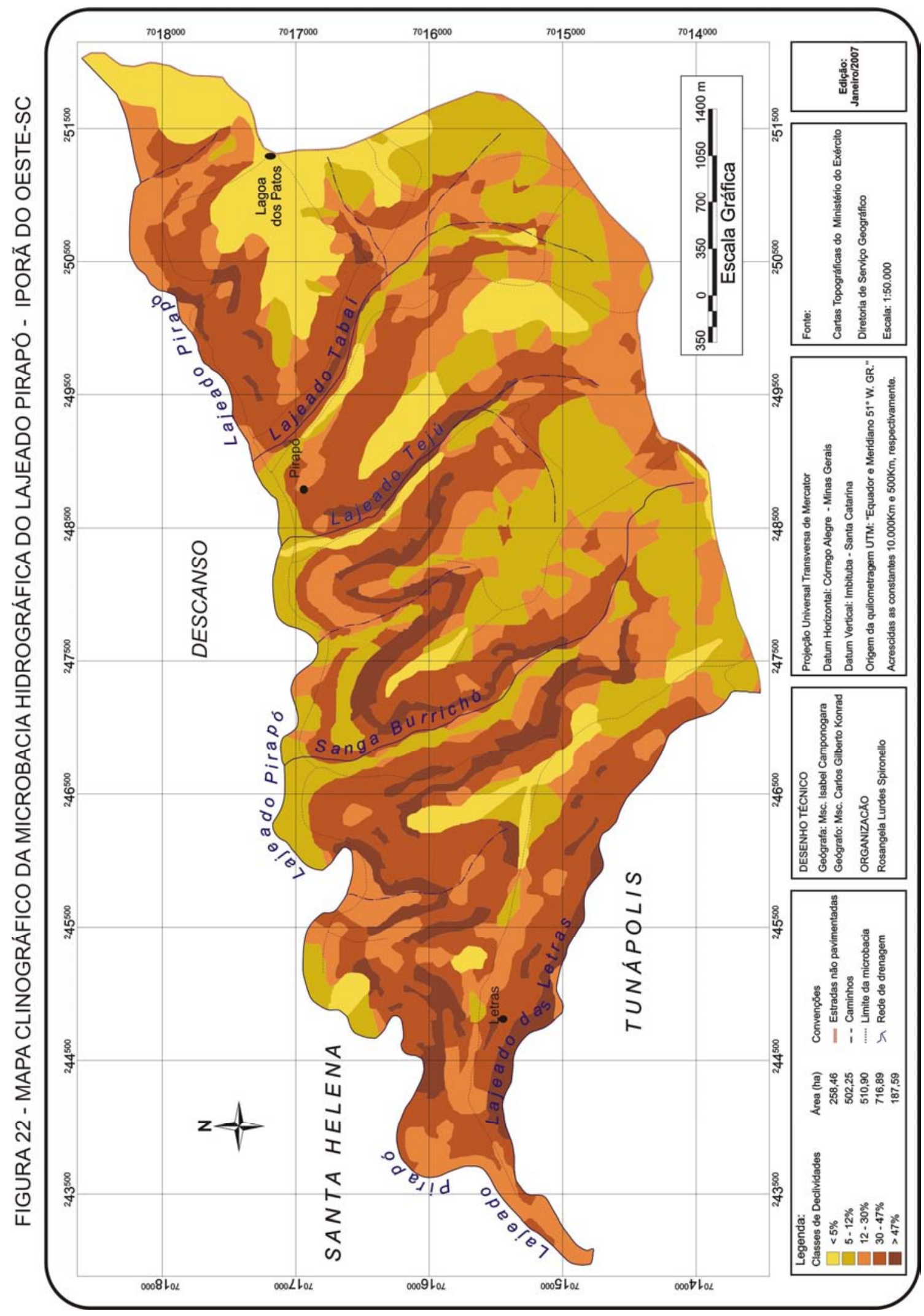


De acordo com os dados, a classe de declividade > de $47 \%$ ocupa um percentual de 8,63\%, ou uma área total da microbacia de 187,59 ha. Esta classe de declividade pode ser percebida ao longo dos afluentes que compõe a microbacia hidrográfica do Lajeado Pirapó.

Com relação ao mapeamento das classes de declividade na microbacia hidrográfica do Lajeado Esperança, tem-se que do total de 2.823,85 ha de área, 315,11 ha, ou seja, $11,16 \%$ da microbacia encontra-se distribuída na classe de declividade de $<$ de 5\%, a qual pode ser visualizada nas porções centro-leste da microbacia e em alguns pontos localizados em topos de morros. Na classe de declividade de 5-12\% têm-se um total de 307,04 ha, abrangendo 10,87\% da área da microbacia, encontrando-se distribuída de forma heterogênea pela microbacia, face a sua pouca expressividade.

Já na classe de declividade de $12-30 \%$ apresenta um aumento considerável de área em relação a anterior, ocupando um total de 833,15 ha, o que perfaz um total de $29,50 \%$ da área de estudo. Esta classe é percebida em toda a extensão da microbacia de forma bem distribuída. Os dados referentes a microbacia hidrográfica do Lajeado Esperança podem ser observados na Tabela 07 e Figura 23.

Tabela 07 - Classes de declividade nas microbacias hidrográficas dos Lajeados Pirapó e Esperança, Município de Iporã do Oeste-SC.

\begin{tabular}{ccccc}
\hline Classes de & \multicolumn{2}{c}{ MLP } & \multicolumn{3}{c}{ MLE } \\
\cline { 2 - 5 } Declividade & Área (ha) & $\%$ & Área (ha) & $\%$ \\
\hline$<5 \%$ & 258,46 & 11,87 & 315,11 & 11,16 \\
$5-12 \%$ & 502,25 & 23,08 & 307,04 & 10,87 \\
$12-30 \%$ & 510,90 & 23,48 & 833,15 & 29,50 \\
$30-47 \%$ & 716,89 & 32,94 & $1.024,76$ & 36,29 \\
$>47 \%$ & 187,59 & 8,63 & 343,79 & 12,18 \\
\hline TOTAL & $2.176,09$ & 100 & $2.823,85$ & 100 \\
\hline Organização: Rosangela L. Spironello, Mar/2007. & &
\end{tabular}

No que se refere às classes de declividade $(30-47 \%$ e $>47 \%)$, que se inserem nas Áreas de Conservação Permanente e de Preservação Permanente, tem-se um total de 1368,55 ha, ou seja, 48,47\% da área. Estas classes de declividade, pela característica de localização (área de encosta), distribuem-se ao longo dos principais cursos de água da microbacia, principalmente a classe de declividade $>47 \%$. Vale lembrar, que por absorver praticamente $50 \%$ da área da microbacia, esta deve ser planejada de forma adequada, visando à manutenção dos 


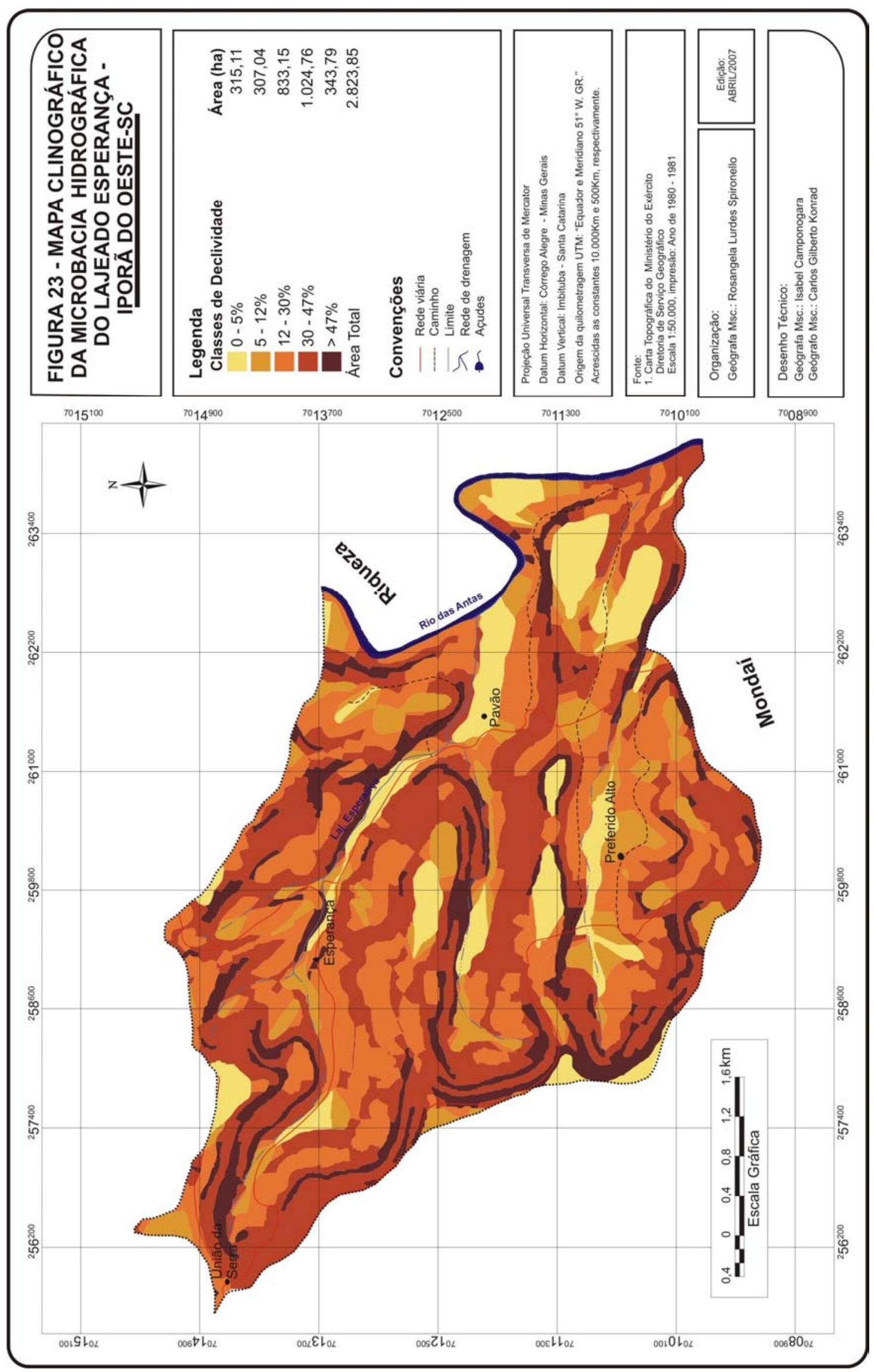


recursos naturais aí existentes, bem como das famílias que residem neste local.

O que pode-se inferir a respeito das áreas de estudo é que a microbacia do Lajeado Esperança apresenta uma pequena diferença nos resultados das porcentagens de declividades acima de $12 \%$, perdendo em área pela declividade de $5-12 \%$ e $<5 \%$, que na microbacia do Lajeado Pirapó, ocupa um total de $23,08 \%$ e respectivamente, $11,87 \%$.

Paralelo a estas informações foi elaborado os mapas hipsométricos das microbacias hidrográficas do Lajeado Pirapó e do Lajeado Esperança. As superfícies das referidas microbacias foram classificadas em quatro classes hipsométricas, variando de 60 em 60 metros.

Para a microbacia hidrográfica do Lajeado Pirapó a variação hipsométrica é de 240 metros, variando as altitudes de $360 \mathrm{~m}$ a $600 \mathrm{~m}$ acima do nível do mar. Os dados relativos ao mapeamento hipsométrico da microbacia hidrográfica poderão ser observados na Figura 24 e Tabela 08.

Tabela 08 - Classes hipsométricas da microbacia hidrográfica do Lajeado Pirapó, Município de Iporã do Oeste-SC.

\begin{tabular}{lll}
\hline Classes hipsométricas & Área (ha) & $\%$ \\
\hline $360-420$ & 247,58 & 11,38 \\
$420-480$ & 468,89 & 21,55 \\
$480-540$ & 605,88 & 27,84 \\
$540-600$ & 853,74 & 39,23 \\
\hline TOTAL & $2.176,09$ & 100 \\
\hline
\end{tabular}

Organização: Rosangela L. Spironello, Mar/2007.

A distribuição da área por classe hipsométrica apresenta um aumento gradativo desde a classe de menor altitude até a de maior altitude, destacando-se a maior área concentrada entre os valores de 540-600 metros de altitude, abrangendo $39,23 \%$ da microbacia. Estas altitudes encontram-se em áreas com declividades entre $12-30 \%$, o que nos permite inferir que este espaço é propício para o desenvolvimento de atividades agrícolas, com técnicas conservacionistas e manejo sustentado, uma vez que conforme identificado in loco, o solo classificado como Latossolos, apresenta uma profundidade de até 2 metros e em algumas porções ocorre a presença do Cambissolos com uma espessura de até $40 \mathrm{~cm}$ (PUNDEK \& MOLINARI, 2001). 


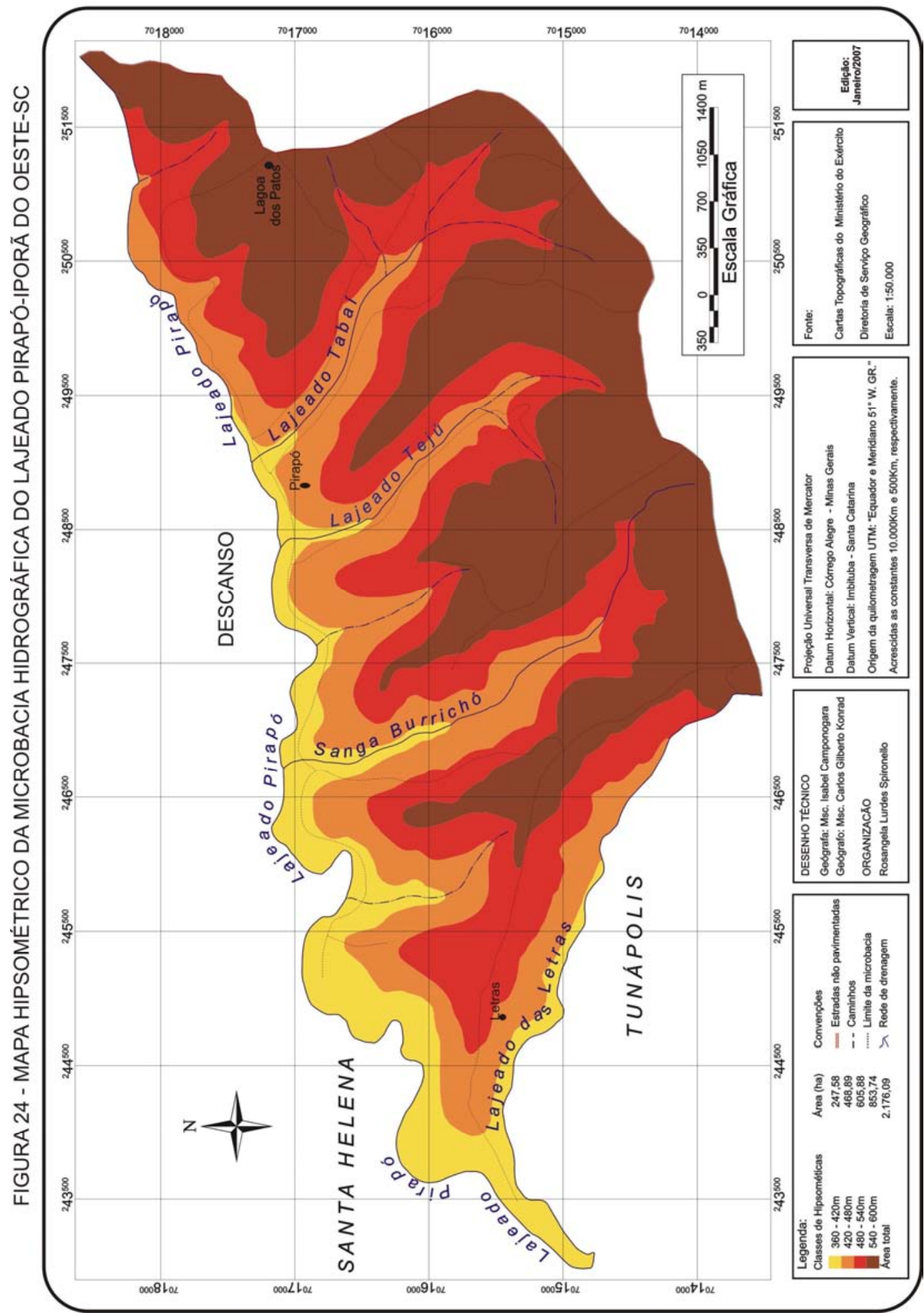

Fgua 24 mapa hipsométrico MLP 
Neste contexto torna-se relevante destacar a importância de se conhecer os diferentes tipos de solos na microbacia, uma vez que os mesmos possibilitam obter uma base de sua caracterização, potencialidades e limitações/riscos de erosão e voçorocamento.

De acordo com levantamentos bibliográficos, de campo e a partir das cartas topográficas, é possível classificar dois principais tipos de solos na microbacia hidrográfica do Lajeado Pirapó: o Latossolo, composto por solos com horizontes bem definidos, os quais podem alcançar uma profundidade de até $200 \mathrm{~cm}$. Cambissolos, solos rasos, com horizonte $B$ incipiente, com a presença de pedregulhos e em alguns casos, o afloramento de rochas. (PUNDEK \& MOLINARI, 2001).

As classes hipsométricas da microbacia do Lajeado Esperança também foram definidas com quatro classes hipsométricas, conforme já destacado anteriormente, com um intervalo de $60 \mathrm{~m}$ em $60 \mathrm{~m}$, com exceção da última classe que assumiu uma classe a mais, ficando num intervalo de $80 \mathrm{~m}$. As altitudes variaram de 240m a 500m acima do nível do mar, obtendo assim, uma variação altimétrica de $260 \mathrm{~m}$. A classe hipsométrica que se estende $240 \mathrm{~m}$ a $300 \mathrm{~m}$ ocupa uma área de 579,90 ha, ou seja, $20,54 \%$ da área da microbacia. A classe hipsométrica que abrange as altitudes de $300 \mathrm{~m}$ a $360 \mathrm{~m}$, apresenta um total de 1.060,42 ha, ou $37,55 \%$ da área em estudo. Já a classe de 360m a 420m conta com 686,76 ha, abrangendo uma porcentagem de área de $24,32 \%$ da microbacia.

Por fim, a classe que se estende entre as altitudes de $420 \mathrm{~m}$ a $500 \mathrm{~m}$ ocupa uma área de 496,76 ha, perfazendo um total de 17,59\% da área.

Os dados referentes à distribuição das classes hipsométricas da microbacia hidrográfica do Lajeado Esperança podem ser observados na Tabela 09 e Figura 25.

Tabela 09 - Classes hipsométricas da microbacia hidrográfica do Lajeado Esperança, Município de Iporã do Oeste-SC.

\begin{tabular}{lll}
\hline Classes hipsométricas & Área (ha) & $\%$ \\
\hline $240-300$ & 579,90 & 20,54 \\
$300-360$ & $1.060,42$ & 37,55 \\
$360-420$ & 686,76 & 24,32 \\
$420-500$ & 496,76 & 17,59 \\
\hline TOTAL & $2.823,85$ & 100 \\
\hline
\end{tabular}

Organização: Rosangela L. Spironello, Mar/2007. 


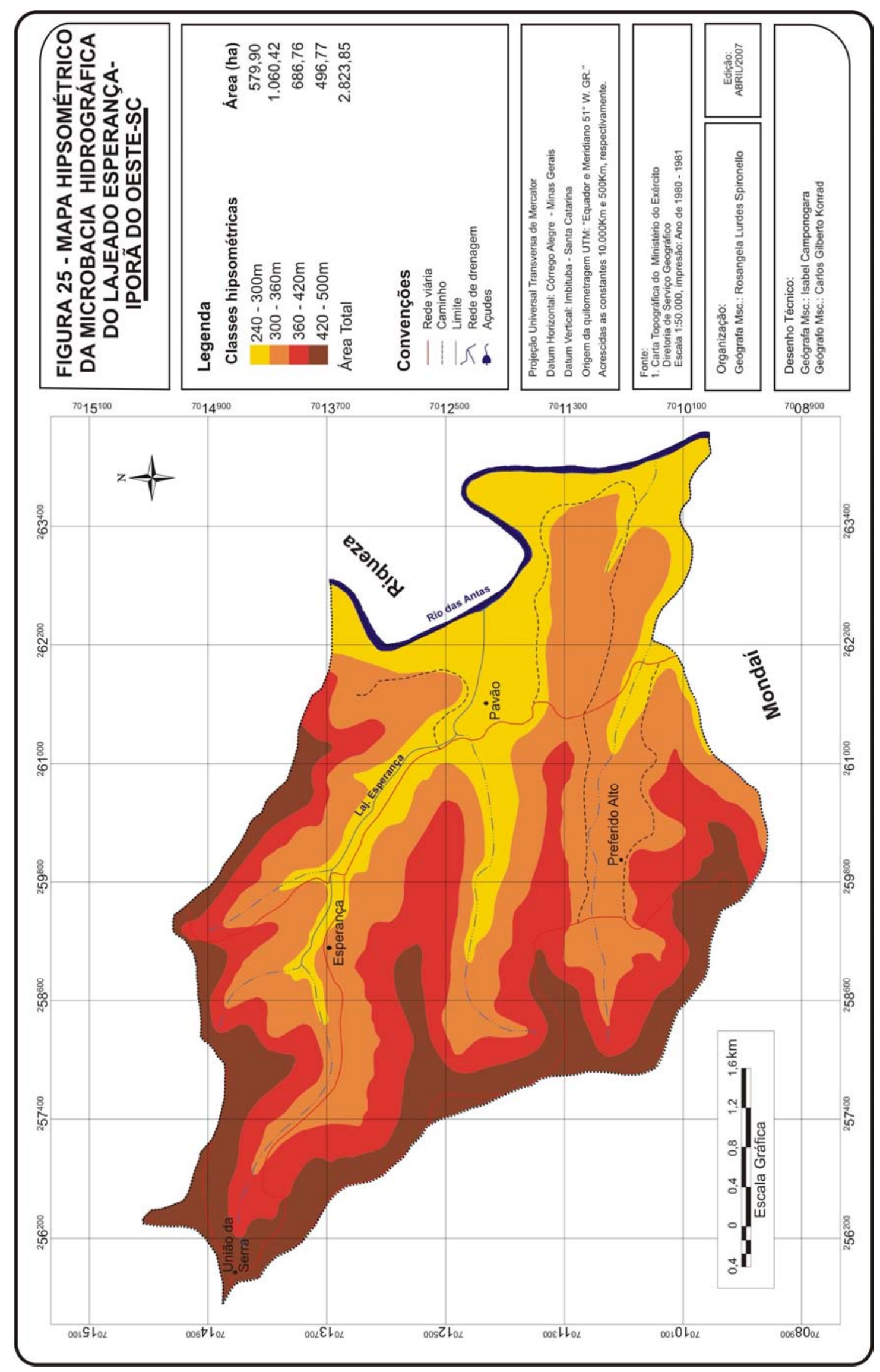


Percebe-se com isso, que as classes hipsométricas encontram-se bem distribuídas, destacando que a classe com maior valor distribui-se espacialmente na sua maior porção na classe de declividade de 12-30 \%, onde tem-se a presença de um solo pouco profundo, com a presença de pedregulhos, característica dos solos do tipo Cambissolos, os quais possuem uma espessura não maior a $40 \mathrm{~cm}$.

Pode-se frisar ainda que esta porção, face a característica geomorfológica e de solos, apresenta uma área propícia ao desenvolvimento de níveis erosivos, caso não haja a aplicação de técnicas de manejo e conservação, podendo ampliar a degradação para as demais classes de declividade.

Já no que diz respeito à rede hidrográfica, a microbacia do Lajeado Pirapó apresenta uma orientação de seus cursos sentido NE-SE. Baseado em Christofoletti (1980), foram classificados os canais pela ordem, ou seja, cursos menores que abrangem canais sem tributários recebem o nome de canais de primeira ordem; passam a ser classificados como canais de segunda ordem quando dois cursos de primeira ordem se interligam; os cursos de terceira ordem são classificados quando surgem da confluência de dois rios ou cursos de primeira ordem. No caso da microbacia hidrográfica do Lajeado Pirapó, pela sua delimitação e por ser uma microbacia de limites municipais, o que consta cartografado são os cursos de primeira e segunda ordem.

Com relação à rede hidrográfica da microbacia hidrográfica do Lajeado Esperança, esta tem sua orientação no sentido NO-SE, desaguando no Rio das Antas, o qual faz divisa com o Município de Iporã do Oeste. As características da rede hidrográfica desta microbacia não diferem da microbacia do Lajeado Pirapó, apresentando também os cursos de primeira e segunda ordem, os quais quando tem-se um período de estiagem de 30 a 40 dias, secam, permanecendo somente 0 curso principal com vazão, comprometendo o fornecimento de água para a dessedentação de pessoas e animais, principalmente a criação de frangos.

5.2.2.1 Áreas de Preservação Permanente (APP) $X$ uso da terra na microbacia hidrográfica do Lajeado Pirapó.

Para compreender e analisar melhor as informações referentes ao uso e ocupação da terra em relação à legislação dentro das microbacias delimitadas 
considerou-se as áreas com declividade $>47 \%$, drenagem $(30 \mathrm{~m})$ e nascentes $(50 \mathrm{~m})$ como Áreas de Preservação Permanente.

De acordo com os dados obtidos a partir da elaboração do mapa de legislação, observou-se que a microbacia hidrográfica do Lajeado Pirapó é ocupada com um total de 347,73 ha de Áreas de Preservação Permanente (APP), o que equivale a $15,98 \%$ do total da microbacia, uma quantidade significativa se levarmos em consideração a importância de se preservar essas áreas para a manutenção dos recursos naturais.

No que se refere à área de preservação permanente com declividade > $47 \%$, tem-se um total de 187,59 ha, o que equivale a $8,62 \%$ do total da microbacia. Já as áreas de preservação permanente definidas com nascente $(50 \mathrm{~m})$ e drenagem (30m) ocupam um total de 160,14 ha, ou seja, 7,36\% da microbacia, conforme podese observar na Figura 26.

Nesse contexto, efetuou-se a sobreposição dos planos de informação, uso da terra x APP para identificar as áreas conflitantes no interior da microbacia, para assim poder inferir ações de minimização de impactos ambientais sobre a mesma. Com a sobreposição obteve-se os seguintes resultados conflitantes: na classe de declividade > 47\%, a classe de uso culturas, ocupa uma área de 12,13 ha, perfazendo um total de 6,47 \% nesta classe de APP.

Os campos ocupam uma área de 48,73 ha, ou seja, 25,97\%. As outras classes de uso da terra (florestas e água) definidas para a pesquisa, obviamente não são caracterizadas como conflitantes, abrangendo respectivamente uma área de 126,02 ha e 0,71 ha, abrangendo $67,78 \%$ do total de 187,59 ha de área de APP em declividade $>47 \%$. Um dado significativo, pois representa a maior porcentagem que se encontra em área protegida pela legislação ambiental. Acredita-se que esta informação poderá servir de impulso para uma maior reflexão de que é possível manter uma estrutura nas propriedades rurais sem prejudicar o meio ambiente.

Já em áreas marginais de mata ciliar, que para a área de estudo os cursos de água não ultrapassam de $10 \mathrm{~m}$, tem-se $30 \mathrm{~m}$ de margem a cada lado do rio e as nascentes comportam um raio de $50 \mathrm{~m}$, de acordo com o Código Florestal Lei $\mathrm{n}^{\circ}$ 4.771 de 1965. O uso da terra campos ocupa uma porção de 51,82 ha, juntamente com as culturas com 10,27 ha, correspondendo a uma porcentagem total de 38,77\% de área de conflito em área de mata ciliar e nascentes. Conforme identificado in loco a margem direita do Lajeado Pirapó (a qual delimita a microbacia na divisa com o 


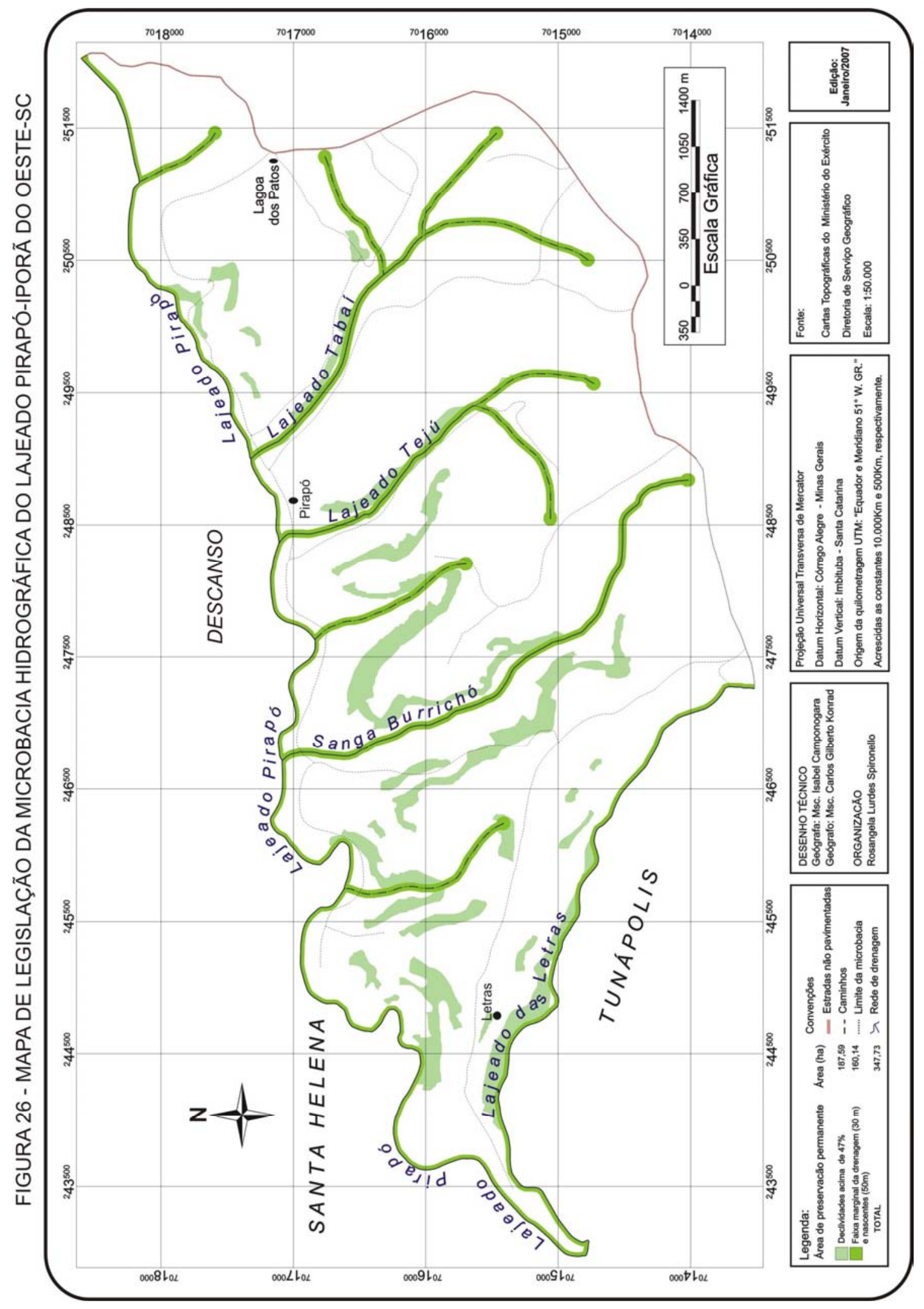


município de Descanso), em algumas porções realmente encontra-se desprovida de mata ciliar, esta que dá o suporte para a minimização dos problemas ambientais na microbacia. A Figura 27 mostra que ocorre a utilização do espaço pelas atividades agrícolas, voltadas à produção de milho, a qual é desenvolvida até bem próximo à margem do Lajeado. Torna-se pertinente destacar aqui, que na margem direita do Lajeado, (município de Descanso) as áreas estão melhor conservadas, pelo fato de ter-se aí um relevo com fortes inclinações. A presença de vegetação nativa, mesclada com algumas espécies de vegetação exótica, contribui de certa forma, para a manutenção da biodiversidade local.

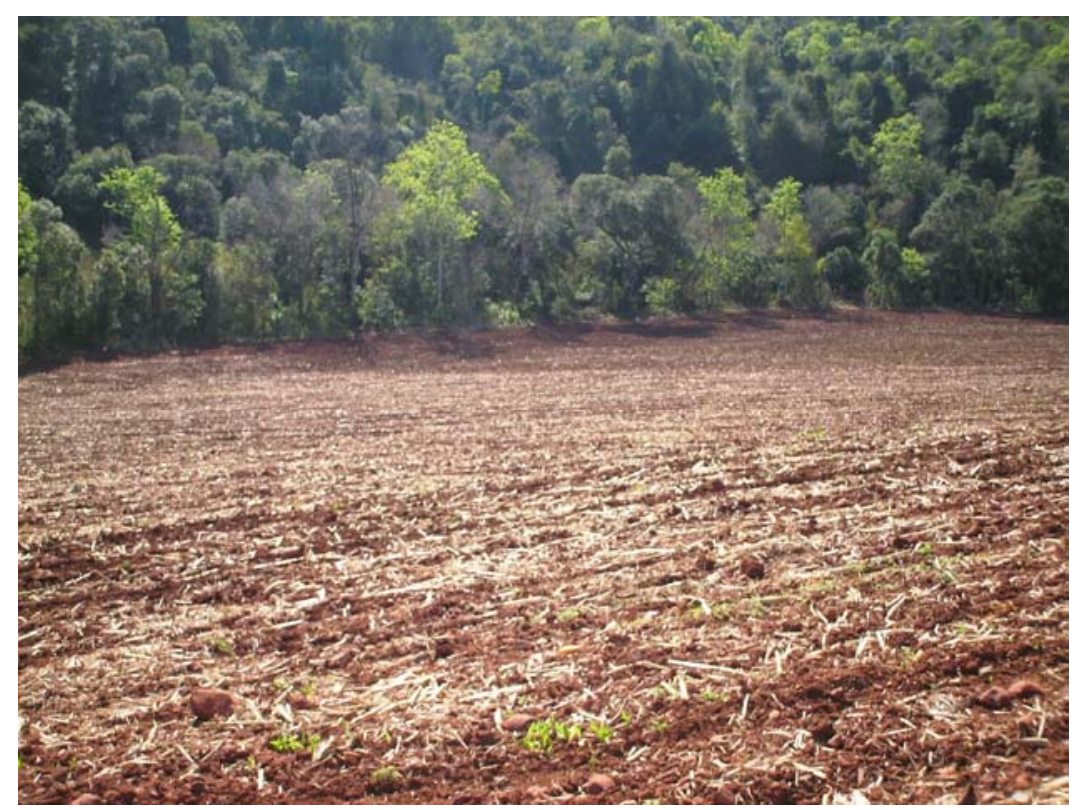

Figura 27 - Área de cultivo de milho até próximo a margem esquerda do Lajeado Pirapó, no Município de Iporã do Oeste-SC.

Organização: Rosangela L. Spironello, Ago/2007.

Fonte: Rosangela L. Spironello, Set/2007.

As áreas de florestas em nascentes e área de mata ciliar mostram um resultado satisfatório, ultrapassando os $60 \%$ de área num total de 160,14 ha de proteção.

Pode-se concluir com isso, que existem conflitos de uso da terra dentro da microbacia, porém a presença de florestas numa porcentagem significativa contribui para a preservação e conservação dos recursos naturais. Os dados relativos ao uso da terra em áreas de proteção permanente podem ser melhor visualizados no Quadro 04 e na Figura 28. 


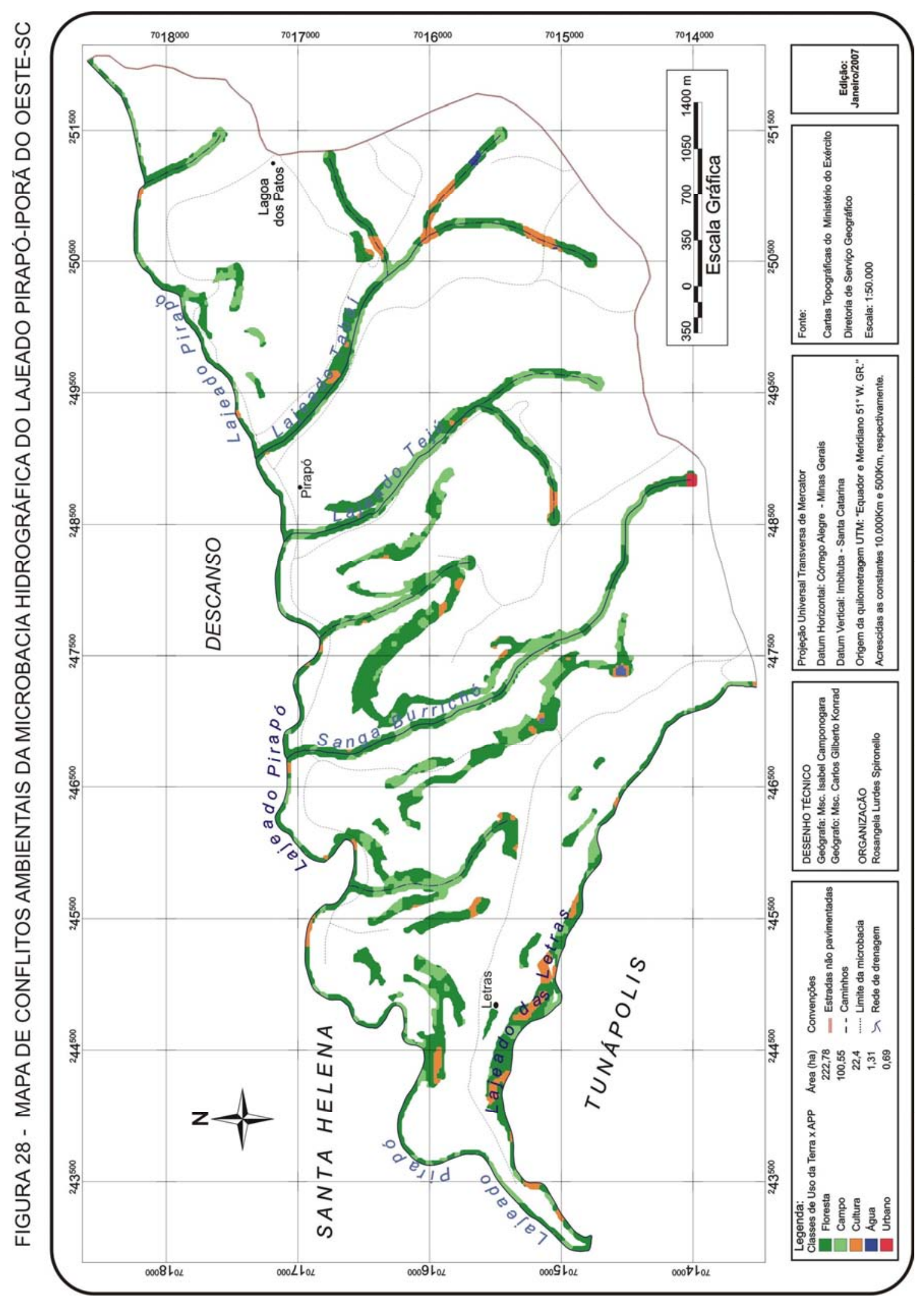


Quadro 04 - Uso da Terra X Áreas de Preservação Permanente na microbacia hidrográfica do Lajeado Pirapó, Município de Iporã do Oesta-SC.

\begin{tabular}{|c|c|c|c|c|c|c|}
\hline \multirow[b]{2}{*}{ Classes } & Área (ha) & & Área (ha) & \multirow[b]{2}{*}{$\%$} & \multirow[b]{2}{*}{$\begin{array}{l}\text { ÁREA } \\
\text { TOTAL }\end{array}$} & \multirow[b]{2}{*}{$\%$} \\
\hline & $\begin{array}{c}\text { Declividade } \\
>47 \%\end{array}$ & $\%$ & $\begin{array}{c}\text { Rede de } \\
\text { Drenagem }(30 \mathrm{~m}) \\
\text { e Nascentes } \\
(50 \mathrm{~m})\end{array}$ & & & \\
\hline Urbano & 0,00 & 0 & 0,69 & 0,43 & 0,69 & 0,20 \\
\hline Culturas & 12,13 & 6,47 & 10,27 & 6,41 & 22,40 & 6,44 \\
\hline Florestas & 126,02 & 67,18 & 96,76 & 60,42 & 222,78 & 64,07 \\
\hline Campos & 48,73 & 25,97 & 51,82 & 32,36 & 100,55 & 28,91 \\
\hline Áqua & 0,71 & 0,38 & 0,60 & 0,38 & 1,31 & 0,38 \\
\hline TOTAL & 187,59 & 100 & 160,14 & 100 & 347,73 & 100 \\
\hline
\end{tabular}

Organização: Rosangela L. Spironello, Abr/2007.

Com base nos dados do relatório de atividades desenvolvidas na microbacia há condições de afirmar que a população inserida na área de estudo encontra-se preocupada com o meio ambiente, tanto é que os mesmos afirmam em questionário e in loco, em conversa informal, que se continuarem a promover ações tradicionais de utilização do espaço, o meio ambiente ficará pior do que está.

Diante de tais colocações, fica clara a intenção de se buscar alternativas de uso adequado do espaço, respeitando os recursos naturais, não deixando de atender às necessidades da população da área de estudo.

5.2.4.1 Áreas de Preservação Permanente (APP) $X$ uso da terra na microbacia hidrográfica do Lajeado Esperança.

A partir do mapeamento realizado na microbacia hidrográfica do Lajeado Esperança, obteve-se os seguintes resultados: das classes de áreas preservação permanente definidas na pesquisa, conforme abordado anteriormente, tem-se um total de 647,44 ha ou $22,93 \%$ da área total da microbacia, como pode-se observar na Figura 29. Das áreas consideradas de preservação permanente, tem-se 343,79 ha, ou seja, $53,10 \%$ de área com declividade acima de $47 \%$. Com relação às áreas de preservação permanente em margens com $30 \mathrm{~m}$ e nascentes com $50 \mathrm{~m}$, obteve-se um total de 303,65 ha, abrangendo $46,90 \%$ da área delimitada.

Para identificar as áreas de conflitos ambientais, na microbacia hidrográfica do Lajeado Esperança, fez-se a sobreposição dos planos de informação (uso da terra x legislação) e obteve-se um total de 71,12 ha de área de campos em APP, ou 


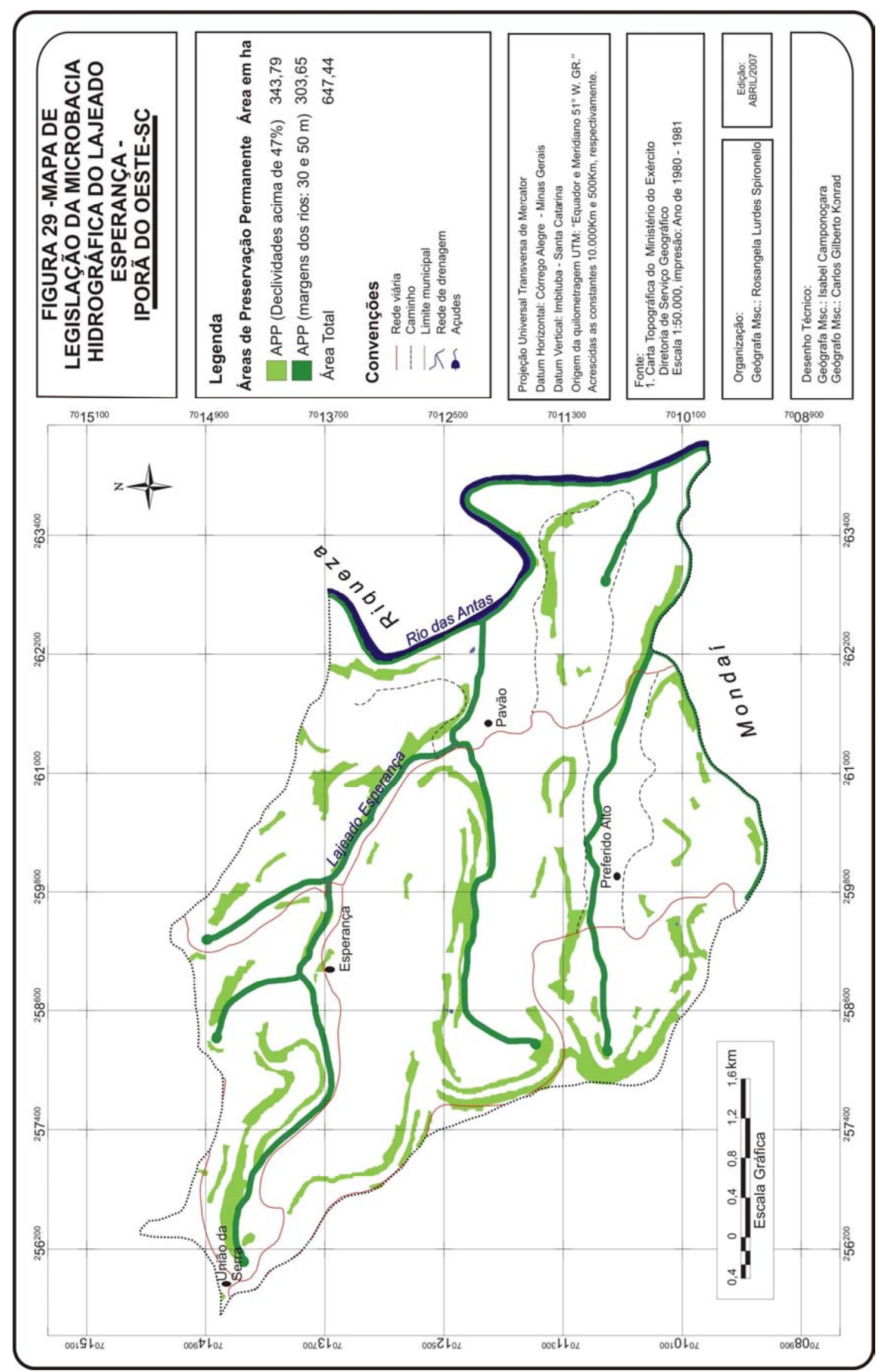


seja, 10,99\% dos 647,44 ha de APP. Outra classe considerada conflituosa dentro da microbacia é a área de culturas, com uma área total de 322,82 ha, ou seja, 49,86\% da área destinada à preservação permanente. Dos quais, 169,73 ha encontram-se distribuídos na classe acima de 47\% e 153,09 em áreas de nascentes (50m) e mata ciliar (30m).

Já as classes de florestas e água não são consideradas áreas de conflitos, no entanto, ocupam uma área de 253,04 ha, perfazendo 39,08\% da área.

Os dados quantificados das áreas de uso da terra em áreas de preservação permanente podem ser visualizados no Quadro 05 e Figura 30.

Quadro 05 - Uso da Terra X Áreas de Preservação Permanente no Lajeado Esperança, Município de Iporã do Oeste-SC

\begin{tabular}{|c|c|c|c|c|c|c|}
\hline \multirow[b]{2}{*}{ Classes } & Área (ha) & \multirow[b]{2}{*}{$\%$} & Área (ha) & \multirow[b]{2}{*}{$\%$} & \multirow[b]{2}{*}{$\begin{array}{l}\text { ÁREA } \\
\text { TOTAL }\end{array}$} & \multirow[b]{2}{*}{$\%$} \\
\hline & $\begin{array}{c}\text { Declividade } \\
>47 \%\end{array}$ & & $\begin{array}{c}\text { Rede de } \\
\text { Drenagem }(30 \mathrm{~m}) \\
\text { e Nascentes } \\
(50 \mathrm{~m})\end{array}$ & & & \\
\hline Urbano & 0,00 & 0,00 & 0,00 & 0,00 & 0,00 & 0,00 \\
\hline Culturas & 169,73 & 49,37 & 153,09 & 50,42 & 322,82 & 49,86 \\
\hline Florestas & 143,24 & 41,67 & 109,80 & 36,16 & 253,04 & 39,08 \\
\hline Campos & 30,79 & 8,96 & 40,33 & 13,28 & 71,12 & 10,99 \\
\hline Água & 0,03 & 0,008 & 0,43 & 0,14 & 0,46 & 0,07 \\
\hline TOTAL & 343,79 & 100 & 303,65 & 100 & 647,44 & 100 \\
\hline
\end{tabular}

Organização: Rosangela L. Spironello, Abr/2007.

Comparando-se os dados com a microbacia hidrográfica do Lajeado Pirapó, pode-se dizer que a microbacia do Lajeado Esperança apresenta maiores áreas de conflitos de uso, principalmente relacionado às culturas, perdendo posição em relação às áreas de campos.

As áreas não conflitantes (florestas e água) na microbacia hidrográfica do Lajeado Esperança, como destacado acima, abrangem um total de 39,09\% da área, em contrapartida, a microbacia hidrográfica do Lajeado Pirapó conta com um total de $64,10 \%$, bem significativo face a importância desse uso para a manutenção da biodiversidade na microbacia e do seu entorno. 


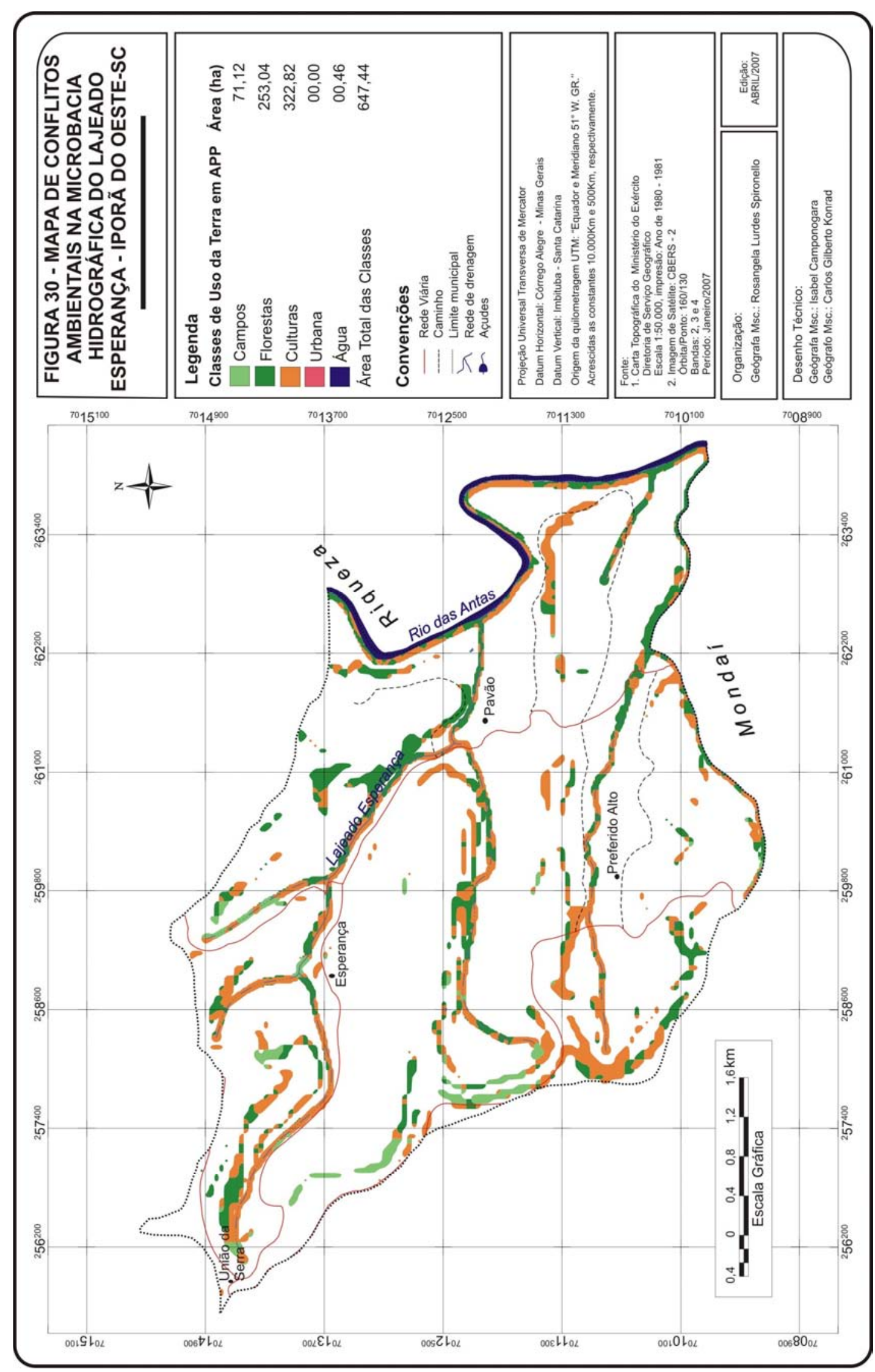


5.3 - PROPOSTA DE ZONEAMENTO-ANTRÓPICO-AMBIENTAL PARA AS MICROBACIAS HIDROGRÁFICAS DO LAJEADO PIRAPÓ E LAJEADO ESPERANÇA.

Com base no levantamento e análise de dados sobre os diferentes usos da terra e os conflitos ambientais nas microbacias hidrográficas delimitadas para o estudo, a partir da legislação, fica evidente a necessidade de elaborar instrumentos que possam auxiliar os planejadores, pesquisadores e os órgãos públicos como prefeituras, proprietários de terras para a melhor utilização dos recursos naturais.

Contudo, pensando em viabilizar a compartimentação por áreas homogêneas e a ocupação do espaço geográfico das microbacias, a partir do zoneamento ambiental e nos projetos ou perspectivas da população, buscou-se por meio de todas as informações levantadas e analisadas, elaborar uma proposta que viesse a atender, ou a encaminhar as ações de melhoria dessas áreas em seu mais variados aspectos, ambientais, sociais e econômicos.

Diante disso, é importante deixar claro que a proposta final de ZoneamentoAntrópico-Ambiental far-se-á em forma de diretrizes, buscando absorver a discussão ou a contribuição da população de cada área delimitada.

Nessa perspectiva, os mapas elaborados numa escala cartográfica aproximada de 1:40.000, nos possibilitaram fazer a correlação das informações, e baseados nos levantamentos de campo, pode-se encaminhar a proposta tendo como orientação metodológica para a delimitação das zonas, a proposta de Rocha (1997, p. 178-179).

Com a finalidade de delimitar as zonas homogêneas nas microbacias, foram utilizadas como parâmetros as declividades, hipsometria, uso da terra e legislação ambiental - Código Florestal Brasileiro, bem como o conhecimento da pesquisadora sobre a área de estudo.

Com a sobreposição dos diferentes produtos cartográficos, foram delimitadas para a pesquisa três zonas parcialmente homogêneas e relativamente distintas entre si, para ambas as microbacias, que são: Zona de Uso e Ocupação Moderada (ZUOM), Zona de Uso e Ocupação Restrita (ZUOR) e Zona de Uso e Ocupação Controlada (ZUOC). 


\subsection{1 - Zoneamento-Antrópico-Ambiental da microbacia hidrográfica do Lajeado Pirapó.}

Na microbacia hidrográfica do Lajeado Pirapó foram identificadas três zonas de compartimentação homogênea a partir do mapeamento efetuado. Os parâmetros de uso da terra, declividades, legislação e hipsometria, foram fundamentais para a delimitação das zonas. Na Tabela 10 e Figura 31 tem-se a distribuição das zonas em ha das distintas áreas.

Tabela 10 - Zonas homogêneas delimitadas na microbacia hidrográfica do Lajeado Pirapó, Município de Iporã do Oeste-SC.

\begin{tabular}{llcc}
\hline ZONAS & ha & $\%$ \\
\hline ZUOM & Zona de Uso e Ocupação Moderada & 809,03 & 37,18 \\
ZUOR & Zona de Uso e Ocupação Restrita & $1.189,47$ & 54,66 \\
ZUOC & Zona de Uso e Ocupação Controlada & 177,59 & 8,16 \\
\hline TOTAL & & $2.176,09$ & 100 \\
\hline
\end{tabular}

Organização: Rosangela L. Spironello, Out/2007.

Do total de 2.176,09 ha na microbacia hidrográfica do Lajeado Pirapó, $37,18 \%$, é abrangido pela ZUOM. Já a ZUOR ocupa $54,66 \%$ da área da referida microbacia e apenas $8,16 \%$ pela ZUOC.

A partir desse resultado, aponta-se a necessidade de se juntar esforços no sentido de estabelecer parâmetros adequados de uso e ocupação do espaço, sem falar da necessidade da instituição de políticas públicas voltadas ao setor local. Essa tarefa requer que se discuta e se planeje o espaço de forma conjunta, poder público municipal e a sociedade local, visando o desenvolvimento "sustentável", adequado à realidade local e regional.

A seguir tem-se a caracterização detalhada de cada Zona de Uso, dentro da microbacia hidrográfica

A ZUOM está localizada na porção leste-sul da microbacia, se estendendo até o divisor de águas da microbacia. O relevo desta Zona é plano, suave ondulado a moderamente ondulado (LEPESCH, 2002) e (EMBRAPA, 1995), onde encontra-se a predominância dos solos do tipo Latossolos, conforme estabelece, Pundek E Mulinari (2001), pois são solos com profundidade que podem alcançar até $200 \mathrm{~cm}$. Também é possível encontrar nessa área algumas parcelas de solos classificados 


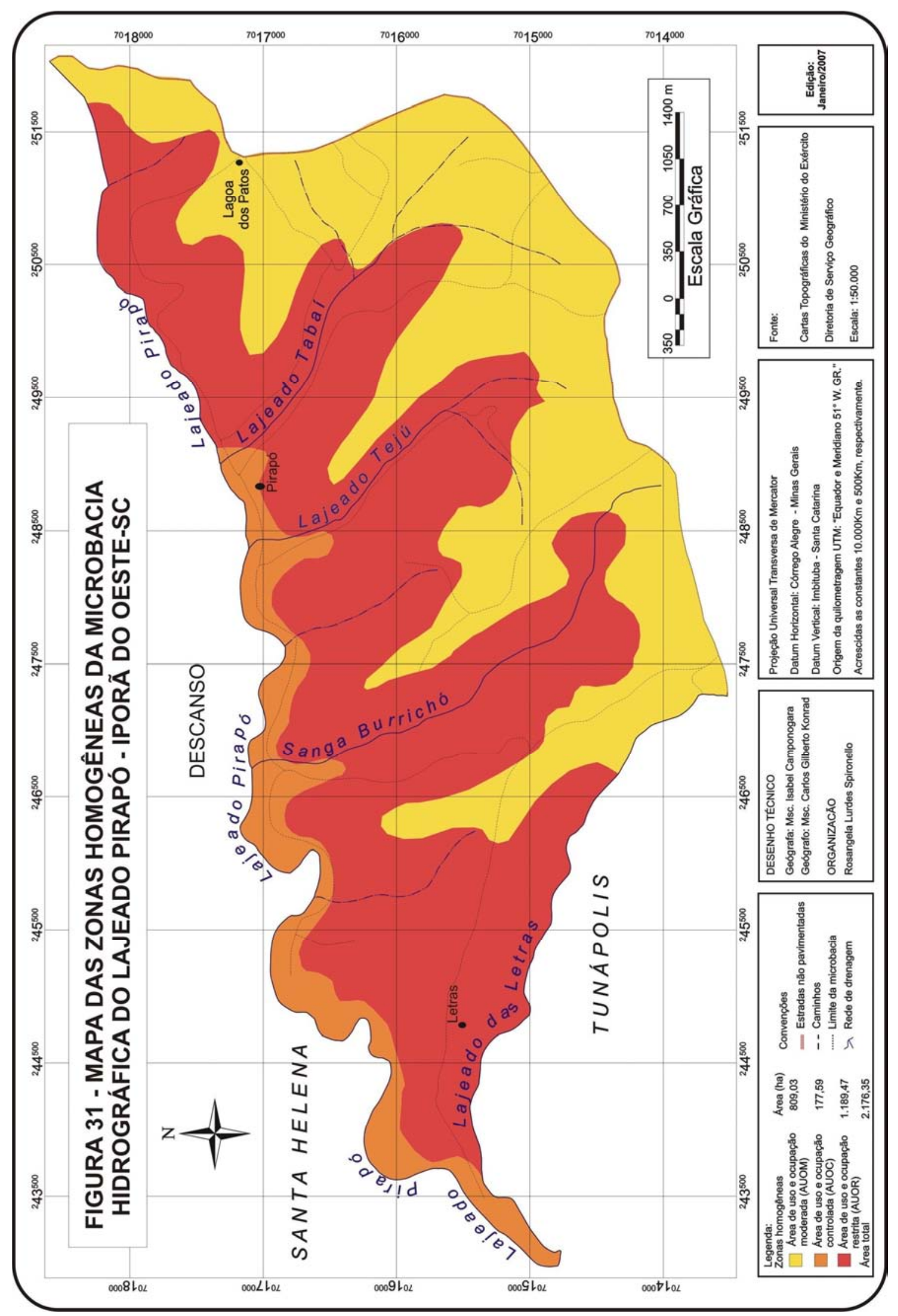


como Cambissolos ${ }^{9}$. Nesta porção as declividades se distribuem-se entre 5-30\%, o que permite ainda a prática de agricultura com manejo conservacionista.

Nesta Zona tem-se a predominância do uso da terra culturas, com a produção de milho, trigo e fumo, face às condições pedológicas e geomorfológicas.

Por ser uma área com uma concentração elevada de nascentes, os agricultores possuem em suas propriedades açudes, os quais possibilitam uma dinamização e diversificação nas atividades econômicas. Na época que antecede a Páscoa, é disponibilizada a toda a população do município e da região uma quantidade expressiva de peixes das mais variadas espécies como: a carpa, o bagre, a tilápia, entre outras.

No ano de 2007, foi implantado um sistema de abastecimento de água para a população das comunidades de São Vendelino e Cabeceira do Taquarussu. Esta água é captada direto de uma fonte, localizada na comunidade de Cabeceira do Taquarussu e possui uma vazão de 9.000 litros $^{3}$ de água/h, a qual é tratada e posteriormente distribuída, contando com um total de $22.500 \mathrm{~m}$ de sistema de canalização para a distribuição.

Algumas áreas de risco ou limitações se fazem presentes pelo fato de englobarem uma área onde se concentram as principais nascentes da microbacia, das quais apresentam níveis de conflito de uso, provocado principalmente pelo uso intensivo do espaço pelas atividades humanas.

No Quadro 06 tem-se a caracterização da zona homogênea (ZUOM) estabelecidas para a microbacia hidrográfica do Lajeado Pirapó.

ZUOR - A Zona de Uso e Ocupação Restrita está localizada na porção central da microbacia. É nesta zona que se encontram as áreas com declividades superiores a $30 \%$ e $>47 \%$, predominando o relevo com características de ondulado a fortemente ondulado, favorecendo o risco de erosão e lixiviação das áreas de encostas. Com base nisso, pode-se dizer que é uma área de difícil manejo da terra, principalmente pelas características topográficas.

Os vales se apresentam com vertentes íngremes e dissecadas. É uma área, na sua maioria, considerada de conservação e preservação permanente e pelo Código Florestal Brasileiro.

\footnotetext{
9 Informações obtidas na Secretaria Municipal da Agricultura de Iporã do Oeste-SC, e em levantamento de campo.
} 
Quadro 06 - Caracterização da zona de uso e ocupação moderada da microbacia hidrográfica do Lajeado Pirapó - Iporã do Oeste-SC

\begin{tabular}{|c|c|c|c|c|c|}
\hline Zonas & Caracterização & Potencialidades & Limitações & $\begin{array}{l}\text { Aspectos } \\
\text { socioeconômico } \\
\text { (uso da terra) }\end{array}$ & $\begin{array}{l}\text { Principais problemas } \\
\text { ambientais (conflitos } \\
\text { ambientais) }\end{array}$ \\
\hline ZUOM & $\begin{array}{l}\text { Corresponde a } \\
\text { grande parte da } \\
\text { microbacia do } \\
\text { Lajeado Pirapó. } \\
\text { Pequenas } \\
\text { propriedades. } \\
\text { Localização de } \\
\text { indústrias de } \\
\text { fabricação de } \\
\text { móveis. }\end{array}$ & $\begin{array}{l}\text { Relevo plano a } \\
\text { levemente ondulado. } \\
\text { Solos profundos e } \\
\text { permeáveis } \\
\text { Acesso asfáltico (no } \\
\text { divisor de água da } \\
\text { microbacia - porção } \\
\text { leste-sul) } \\
\text { Atividades econômicas } \\
\text { predominantes na } \\
\text { área: culturas, campos, } \\
\text { (açudes para produção } \\
\text { de peixes), bem como } \\
\text { de avários. } \\
\text { Extração de água para } \\
\text { abastecimento da } \\
\text { população. }\end{array}$ & $\begin{array}{l}\text { Área de muitas } \\
\text { nascentes } \\
\text { Uso de agricultura } \\
\text { em nascentes e } \\
\text { margens dos cursos } \\
\text { d' água. }\end{array}$ & $\begin{array}{l}\text { Distribuição da } \\
\text { população de } \\
\text { forma dispersa. } \\
\text { Utilização de mão- } \\
\text { de-obra familiar e } \\
\text { contratada. } \\
\text { Predominância da } \\
\text { produção de milho, } \\
\text { trigo e fumo. } \\
\text { Atividades de } \\
\text { criação de aves e } \\
\text { gado de leite. }\end{array}$ & $\begin{array}{l}\text { Poucos fragmentos de } \\
\text { mata nativa (pinheiro) } \\
\text { Poluição dos cursos d' } \\
\text { água por agrotóxicos e } \\
\text { dejetos (suínos e aves) }\end{array}$ \\
\hline
\end{tabular}


Alguns problemas ambientais foram detectados, como o desmatamento em áreas de encostas, principalmente na margem esquerda dos cursos d'água. A poluição dos recursos hídricos por agrotóxicos e dejetos (suínos e aves).

As propriedades por se constituírem de pequeno porte (propriedades que variam de 12 a 20 ha), tem a predominância da mão-de-obra familiar, voltada à produção de produtos para a subsistência como a mandioca e o feijão. Ocorre nessa porção, também, o cultivo do milho e do fumo, os quais são normalmente destinados às empresas nas quais os produtores se encontram filhados.

Por outro lado pode-se destacar algumas potencialidades, como a presença significativa de florestas nativas, com regeneração de mata secundária, e alguns outros fragmentos de vegetação exótica, como a uva-do-japão. Estas áreas de mata são encontradas principalmente costeando os afluentes das margens direita do Lajeado Pirapó. Nesta classe predominam as altitudes de 240m a 540m.

O Quadro 07 mostra a caracterização da ZUOR para a microbacia do Lajeado Pirapó.

A Zona de Uso e Ocupação Controlada (ZUOC) está localizada na porção mais baixa da microbacia, abrangendo as áreas com altitudes que variam de 360 a 420m, aproximadamente. Esta zona se distribui ao longo do curso principal do Lajeado Pirapó, perpassando por declividades variadas, predominando as classes de 5-12\%. Nesta área é possível identificar conforme Pundek e Molinari (2001), os solos denominados Latossolos, Cambissolos e em algumas pequenas extensões com a presença de Gleissolos, face às áreas de deposição de sedimentos (oriundos das áreas declivosas da microbacia) ao longo do médio curso do Lajeado. Destaca-se que nessas áreas os solos possuem profundidade variada $(40 \mathrm{~cm}$ a $150 \mathrm{~cm})$, porém com suscetibilidades a erosão e assoreamento, face à variação das declividades e aos usos da terra inadequados.

Como o mapeamento da microbacia buscou respeitar os limites administrativos, percebeu-se que ocorre uma utilização intensa dessas áreas destinadas às atividades agrícolas (produção de milho, fumo, pastagens e produtos destinados à subsistência das famílias proprietárias das terras). Ocorre nesta zona, como nas demais zonas, o uso de defensivos agrícolas, por parte dos agricultores, poluindo os cursos d' água. Os dejetos de suínos, aves e humanos, apesar de não tão intensos, também contribuem para aumentar os índices de vulnerabilidade nessa área. 
Quadro 07 - Caracterização da zona de uso e ocupação restrita na microbacia hidrográfica do Lajeado Pirapó - Iporã do Oeste-SC.

\begin{tabular}{|c|c|c|c|c|c|}
\hline Zonas & Caracterização & Potencialidades & Limitações & $\begin{array}{l}\text { Aspectos } \\
\text { socioeconômicos } \\
\text { (uso da terra) }\end{array}$ & $\begin{array}{l}\text { Principais problemas } \\
\text { ambientais (conflitos } \\
\text { ambientais) }\end{array}$ \\
\hline ZUOR & $\begin{array}{l}\text { Corresponde a } \\
\text { extensas áreas com } \\
\text { declividades acima } \\
\text { de } 30 \% \text { e > de } 47 \% \\
\text { Pequenas } \\
\text { propriedades. } \\
\text { Predominância da } \\
\text { mão de obra familiar. } \\
\text { Produção } \\
\text { principalmente } \\
\text { voltada à } \\
\text { subsistência das } \\
\text { famílias. }\end{array}$ & $\begin{array}{l}\text { Presença significativa } \\
\text { de florestas (nativas) } \\
\text { com regeneração de } \\
\text { mata (vegetação } \\
\text { secundária) } \\
\text { Atividades econômicas } \\
\text { predominantes na } \\
\text { área: culturas (milho, } \\
\text { feijão e fumo). } \\
\text { Fragmentos de áreas } \\
\text { de proteção } \\
\text { permanente } \\
\text { preservadas }\end{array}$ & $\begin{array}{l}\text { Relevo ondulado } \\
\text { a fortemente } \\
\text { ondulado. } \\
\text { Uso de } \\
\text { agricultura nas } \\
\text { margens dos } \\
\text { cursos d' água e } \\
\text { em encostas. } \\
\text { Solos rasos, } \\
\text { suscetíveis à } \\
\text { erosão. } \\
\text { Dificuldade de } \\
\text { acesso a } \\
\text { algumas } \\
\text { propriedades face } \\
\text { a inclinação do } \\
\text { relevo. } \\
\text { Área com fortes } \\
\text { restrições para as } \\
\text { atividades } \\
\text { voltadas à } \\
\text { aqricultura. }\end{array}$ & $\begin{array}{l}\text { Distribuição da } \\
\text { população de forma } \\
\text { dispersa. } \\
\text { Utilização de mão de } \\
\text { obra } \\
\text { predominantemente } \\
\text { familiar. } \\
\text { Predominância da } \\
\text { produção de milho, } \\
\text { feijão e fumo. }\end{array}$ & $\begin{array}{l}\text { Desmatamento em } \\
\text { áreas de encostas e } \\
\text { principalmente na } \\
\text { margem esquerda dos } \\
\text { cursos d' água. } \\
\text { Poluição dos cursos d' } \\
\text { água por agrotóxicos e } \\
\text { dejetos (suínos e } \\
\text { aves). }\end{array}$ \\
\hline
\end{tabular}


Destaca-se também que o acesso às propriedades é facilitado, pois a estrada de chão batido, classificada como secundária, encontra-se em bom estado de conservação e se estende por praticamente toda a extensão da microbacia, margeando o curso principal do lajeado. É nessa porção que encontra-se localizada a sede da comunidade, contendo uma igreja e um salão comunitário, onde a população local se reúne para as festas e reuniões quando agendadas. É nesse local que os idosos se encontram-se para os momentos de lazer, organizando atividades de jogos de bocha, bocha 48, baralho, entre outros.

Nessa zona encontra-se instalada a sub-estação de tratamento de água da CASAN (Companhia Catarinense de Abastecimento de Águas e Saneamento), a qual abastece a população urbana do município de Iporã do Oeste-SC. A água que é distribuída à população urbana é capturada do rio por uma bomba, sendo depositada em um tanque, a qual passa por todo o tratamento necessário, que é feito por um responsável técnico do próprio órgão. De acordo com as informações obtidas in loco, e em conversa informal com o técnico responsável, a água que chega até o reservatório para ser tratada, nos últimos anos, tem se mostrado com índices menores de poluição, pelo menos com relação ao lançamento nos cursos d' água de pequenos detritos, solos, entre outros. Isso se deve ao fato de as áreas florestadas terem aumentado gradativamente ao longo das encostas nos últimos anos, e a própria conscientização da população com relação à questão ambiental.

As atividades econômicas predominantes nessas áreas são semelhantes às demais zonas, com o destaque à produção de frutíferas como o pêssego, por exemplo. A atividade com o gado leiteiro também é exercida nesse espaço, onde tem-se algumas porções de terras destinadas ao plantio de pastagem e criação de. gado em sistema semi-extensivo. A mão-de-obra empregada nas propriedades é essencialmente familiar, com raras exceções de contratações temporárias, em épocas de plantio e colheita de fumo e milho. No Quadro 08 tem-se caracterizada a ZUOC, na microbacia em estudo. 
Quadro 08 - Caracterização da zona de uso e ocupação controlada na microbacia hidrográfica do Lajeado Pirapó - Iporã do Oeste-SC.

\begin{tabular}{|c|c|c|c|c|c|}
\hline Zonas & Caracterização & Potencialidades & Limitações & $\begin{array}{l}\text { Aspectos } \\
\text { socioeconômicos } \\
\text { (uso da terra) }\end{array}$ & $\begin{array}{l}\text { Principais problemas } \\
\text { ambientais (conflitos } \\
\text { ambientais) }\end{array}$ \\
\hline \multirow[t]{2}{*}{ ZUOC } & $\begin{array}{l}\text { Corresponde a de } \\
\text { baixas altitudes }\end{array}$ & $\begin{array}{l}\text { Áreas planas, rica em } \\
\text { matéria orgânica. }\end{array}$ & $\begin{array}{l}\text { Utilização de } \\
\text { agrotóxicos, os quais } \\
\text { contaminam a água que } \\
\text { é tratada para abastecer } \\
\text { a população da área } \\
\text { urbana do município. }\end{array}$ & $\begin{array}{l}\text { Distribuição da } \\
\text { população de forma } \\
\text { dispersa. }\end{array}$ & $\begin{array}{ll}\text { Desmatamento } & \text { na } \\
\text { margem esquerda do } \\
\text { curso d' água do } \\
\text { Lajeado. }\end{array}$ \\
\hline & \begin{tabular}{l} 
Estação \\
tratamento de água \\
(CASAN) \\
Pequenas \\
propriedades r e \\
predominância da \\
mão-de-obra familiar. \\
Produção voltada ao \\
comércio e a \\
subsistência das \\
famílias. \\
\multicolumn{4}{l}{} \\
Localização da \\
comunidade (igreja e \\
salão de festas)
\end{tabular} & 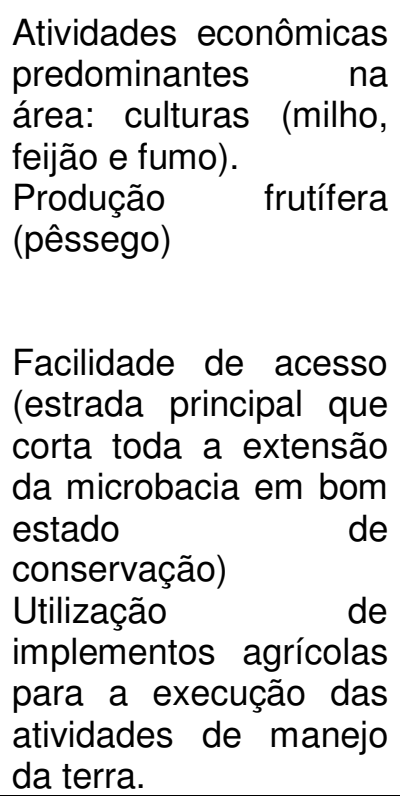 & $\begin{array}{l}\text { Uso de agricultura e } \\
\text { pastagens (campos) nas } \\
\text { margens dos cursos d' } \\
\text { água. } \\
\text { Solos argilosos nas } \\
\text { margens do curso } \\
\text { principal do Lajeado. } \\
\text { Assoreamento do curso } \\
\text { d'água. }\end{array}$ & $\begin{array}{l}\text { Utilização de mão- } \\
\text { de-obra } \\
\text { predominantemente } \\
\text { familiar } \\
\text { Predominância da } \\
\text { produção de milho, } \\
\text { feijão e fumo. }\end{array}$ & $\begin{array}{l}\text { Poluição dos cursos d' } \\
\text { água por agrotóxicos e } \\
\text { dejetos (suínos e aves) }\end{array}$ \\
\hline
\end{tabular}


5.3.1.1 - Zonas homogêneas $X$ perspectivas da população na microbacia hidrográfica do Lajeado Pirapó

Diante dos dados levantados, discutidos e analisados a partir da definição das zonas homogêneas, elaborou-se a proposta de uso/ações adequadas em cada zona homogênea delimitada na microbacia, tecendo um paralelo com os projetos (perspectivas) da população residente na área de estudo, os quais foram levantados durante as discussões no Projeto Microbacias II.

Posterior à delimitação das zonas homogêneas para a área de estudo buscou-se em cada zona destacar, de forma sucinta, qual é o cenário atual dentro da microbacia, chamando a atenção para os usos proibidos e tolerados.

Da mesma forma levou-se em consideração os projetos elencados pela população como prioridades a serem desenvolvidas dentro da microbacia, e a partir daí, elaborar um cenário para as referidas perspectivas da população, destacando o que é possível incentivar ou não a partir do zoneamento ambiental elaborado. A proposta para a ZUOM encontra-se estruturada no Quadro 09.

Na ZUOM, o cenário atual nos mostra que a área apresenta um relevo plano a suavemente ondulado, possibilitando o desenvolvimento de diversas atividades voltadas à produção agrícola e não agrícola. Nessa porção da microbacia tem-se localizadas a maioria das nascentes que formam o conjunto da rede hidrográfica.

O acesso tanto para a microbacia como para qualquer outra porção do município e municípios vizinhos é facilitado pela presença da SC 486. Tal rodovia torna-se importante neste cenário não somente por facilitar o transporte de pessoas de um lugar para o outro, mas inclusive, por facilitar de forma mais rápida, o deslocamento de possíveis produtos perecíveis destinados aos mercados consumidores da região.

Com relação aos usos proibidos caracterizados para essa zona, tem-se o avanço de desmatamento em áreas de nascentes, não deixando de ser menos importante destacar a utilização de agrotóxicos e outros defensivos nos solos e a liberação de dejetos de suínos, de aves e de humanos. 
Quadro 09 - Proposta de Zoneamento-Antrópico-Ambiental para a ZUOM na microbacia hidrográfica do Lajeado Pirapó-Iporã do Oeste-SC

\begin{tabular}{|c|c|c|c|c|c|}
\hline Zonas & Cenário atual & Usos proibidos & Tolerados & $\begin{array}{l}\text { Projetos } \\
\text { levantados e } \\
\text { desejados pela } \\
\text { população para } \\
\text { toda a microbacia }\end{array}$ & $\begin{array}{l}\text { Cenário projetado e a } \\
\text { incentivar na ZUOM. }\end{array}$ \\
\hline ZUOM & 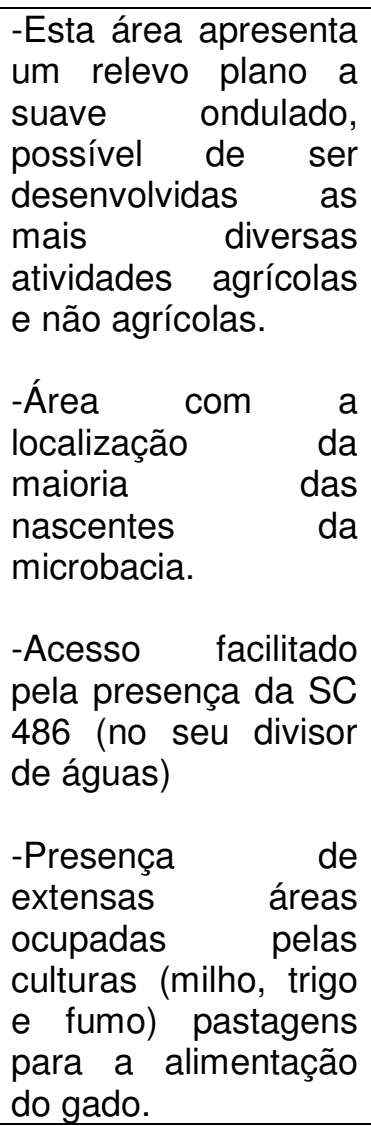 & $\begin{array}{l}\text {-Avanço de } \\
\text { desmatamento em } \\
\text { áreas de nascentes. } \\
\text {-Liberação de dejetos } \\
\begin{array}{l}\text { de suínos, aves e } \\
\text { humanos; } \\
\text {-Utilização de } \\
\text { agrotóxicos e outros } \\
\text { biocidas, os quais } \\
\text { prejudicam a saúde da } \\
\text { população. }\end{array}\end{array}$ & \begin{tabular}{l}
-Uso de agricultura \\
e pastagens \\
(campos) \\
respeitando as \\
margens dos \\
cursos d' água e \\
nascentes. \\
\multicolumn{4}{c}{} \\
-Culturas em áreas \\
com suaves \\
ondulações, \\
mediante a \\
utilização de de \\
práticas de manejo \\
e conservação do \\
solo, para o \\
controle de erosão.
\end{tabular} & $\begin{array}{l}\text {-Industrialização da } \\
\text { madeira; } \\
\text { produção de (mel, } \\
\text { alimentos do } \\
\text { peixes, fruticultura, } \\
\text { horticultura); } \\
\text {-Agroecologia; } \\
\text {-Conservação do } \\
\text { solo. } \\
\text {-Habitação. } \\
\text {-Mini-indústria do } \\
\text { leite (produção de } \\
\text { manteiga, iogurte, } \\
\text { queijos, nata, doce } \\
\text { de leite, requeijão } \\
\text { entre outros). } \\
\text {-Gado de leite. }\end{array}$ & $\begin{array}{l}\text {-Processamento } \\
\text { artesanal de produtos } \\
\text { (mel, frutas, e peixes). } \\
\text {-Criação de alevinos. } \\
\text {-Instalação de novas } \\
\text { agroindústrias de. } \\
\text {-Leite. } \\
\text {-Sucos. } \\
\text {-Madeira. } \\
\text {-Criação de gado de } \\
\text { leite em semi- } \\
\text { confinamento. } \\
\text {-Ampliação de áreas } \\
\text { florestadas. }\end{array}$ \\
\hline
\end{tabular}


Sobre os usos tolerados para a ZUOM, destaca-se o uso da agricultura e pastagens, buscando respeitar a legislação ambiental, principalmente no que diz respeito as nascentes (50m de raio) e cursos d' água (30m de mata ciliar). Nessa área também é tolerado o uso de culturas em áreas com declives com suaves ondulações, mediante a utilização de práticas conservacionistas, objetivando a minimização ou o controle dos níveis de erosão.

A população da microbacia tem elencado em suas propostas inúmeros projetos, estabelecidos como prioritários, dentre eles pode-se destacar: a industrialização de madeira destinada à fabricação de móveis. Esta por sua vez pode ser incentivada com o acompanhamento e o monitoramento sobre a matériaprima adquirida, a qual pode ser produzida dentro da própria microbacia, desde que se elaborem projetos de implantação e manejo de florestas voltadas a este setor.

Outro projeto prioritário destacado pelos produtores é a necessidade da implantação de mini-indústria de beneficiamento do leite, incluindo aí a produção de manteiga, queijos, iogurte, nata, entre outros. A produção de mel, peixes, fruticultura e horticultura são outras propostas de projetos voltadas à microbacia, no intuito de atender as necessidades da população, gerando nova renda e agregando valor à produção local.

Tais iniciativas poderão ser incentivadas por vários motivos: a localização geográfica beneficia e possibilita o acesso e o transporte de pessoas e mercadorias para o mercado consumidor (feira municipal, por exemplo). Para a implantação desse tipo de atividade, deve-se levar em conta alguns fatores, como: se existe matéria-prima para a industrialização, se há mercado consumidor para os produtos e se o poder público municipal se mostra interessado em prestar toda a assistência necessária para a organização, qualificação e planejamento dos grupos interessados.

A produção agroecológica também foi levantada como possibilidade de implantação. Porém, nesse caso, os agricultores necessitariam de promover uma mudança brusca na maneira de apropriação do espaço a partir do uso da terra. Nesta zona, tem-se a utilização intensa de defensivos agrícolas, provocando a contaminação do solo e dos recursos hídricos. Dessa forma, a produção agroecológica poderia ser viabilizada, sem nenhuma restrição, a partir do momento em que toda a população se conscientizasse sobre a não utilização de agrotóxicos em suas propriedades e nas adjacências. Esta tarefa não é fácil, pois a mudança de 
cultura sobre a utilização racional do espaço geográfico é um processo gradativo e exige acima de tudo, vontade de mudar. O comodismo ainda reina no pensamento de muitas pessoas e isso dificulta ou até mesmo impede o avanço, principalmente no que diz respeito à qualidade de vida e ambiental.

A atividade voltada à produção de leite é um dos projetos que já existe e que busca-se incentivar dentro do projeto microbacias. Porém, chama-se a atenção sobre as potencialidades e limitações que esta atividade pode refletir no espaço. Os pontos positivos que se pode destacar é que os animais podem ser utilizados para a tração animal e para a produção do leite, sem falar da possibilidade de aproveitar as áreas de cultivo para a pastagem no inverno. As restrições dizem respeito principalmente à questão da compactação do solo pelo pisoteio do gado e os uso de possíveis áreas de APP para a criação de animais. Se a população respeitar os espaço e planejar de forma adequada suas propriedades, a produção de leite pode ser uma fonte de renda potencial para as famílias.

Projetos de conservação do solo nas propriedades de toda a microbacia e em especial da ZUOM, também são levantados e poderão ser incentivados pelo fato de que nessas propriedades ocorre a utilização intensa da terra, subtraindo assim, os materiais orgânicos face à produção de milho, fumo, trigo e produtos voltados a subsistência.

O cenário desejado para a microbacia pode estar absorvendo todas as necessidades da população, elencadas acima, desde que se respeite o meio ambiente e que o planejamento das propriedades seja uma constante dentro das famílias. O poder público municipal, juntamente com os órgãos responsáveis (EPAGRI e Secretaria da Agricultura, em especial), são peças importantes no processo de implementação e execução das atividades.

Sugere-se também para essa zona a ampliação de áreas florestadas, por se tratar de um espaço que abrange a grande maioria das nascentes e estas necessitam ser preservadas para garantir o fornecimento de água não somente em superfície, mas em sub-superfície, mantendo consequentemente a umidade do solo.

No que diz respeito a ZUOR, esta apresenta um relevo com declives acentuados a fortemente acentuados em áreas de conservação e preservação permanente, com porções significativas de florestas nativas e vegetação secundária ao longo das encostas da margen direita dos afluentes do Lajeado Pirapó. Inclui-se 
nessa zona, porções de áreas destinadas às atividades agrícolas, voltadas à produção de milho, feijão, fumo e pastagem para a alimentação do gado.

Fica proibida nessa zona: a construção de casas ou galpões sem o planejamento e orientação com relação às normas ambientais; a utilização intensa da terra, pois os solos são de maneira geral, rasos e suscetíveis à erosão e deslizamentos.

Quanto aos usos tolerados, orienta-se a utilização do espaço com práticas de culturas consorciadas a partir de manejo sustentado, visando o controle da erosão.

Dentro dos projetos ou perspectivas elencadas pela população na microbacia, o cenário projetado a incentivar nessa área deve levar em consideração o fator topográfico e de solos, na execução de determinadas atividades. Dentre as projeções, sugere-se a ampliação de áreas florestadas, em consórcio com espécies frutíferas para a diversificação da produção nas propriedades. Visando a melhoria na condição social, orienta-se a construção de casas e galpões (para guardar a produção e equipamentos) dentro dos parâmetros exigidos pela legislação, para não comprometer as bem-feitorias e o solo, que nessa porção requer manejo e conservação. No Quadro 10, está caracterizada a proposta para a ZUOR, na microbacia hidrográfica do Lajeado Pirapó.

A ZUOC caracteriza-se por apresentar uma área com relevo plano e com suaves ondulações. O solo, principalmente no médio curso do lajeado, possui uma reserva orgânica rica, possibilitando aí o desenvolvimento das atividades voltadas à horticultura. Esta atividade torna-se facilitada também pelo fato de o acesso às propriedades e a área urbana de Iporã do Oeste se encontrar em bom estado de conservação.

Outros tipos de culturas são encontradas nessa área, as quais são produzidas pelos agricultores com mão-de-obra essencialmente familiar. Porém, chama-se a atenção para os usos tolerados voltados às culturas. Estas, por sua vez, podem ser desenvolvidas com planejamento e manejo adequado, evitando a perda de solo e a própria compactação do mesmo pelo gado, quando criado em sistema semi-confinado. Contudo, deve-se respeitar os limites das margens dos rios para que não acorra seu assoreamento. 
Quadro 10 - Proposta de Zoneamento-Antrópico-Ambiental para a ZUOR na microbacia hidrográfica do Lajeado Pirapó-Iporã do Oeste-SC

\begin{tabular}{|c|c|c|c|c|c|}
\hline Zonas & Cenário atual & Usos proibidos & Tolerados & $\begin{array}{l}\text { Projetos levantados e } \\
\text { desejados pela } \\
\text { população para toda a } \\
\text { microbacia }\end{array}$ & $\begin{array}{l}\text { Cenário projetado e a } \\
\text { incentivar na ZUOR. }\end{array}$ \\
\hline ZUOR & $\begin{array}{l}\text {-Esta área apresenta } \\
\text { um relevo ondulado, } \\
\text { com áreas de declives } \\
\text { acima de } 30 \% \text { a } 47 \% \text {, } \\
\text { considerados em } \\
\text { praticamente toda a } \\
\text { porção, áreas de ACP } \\
\text { e APP. } \\
\text { - Presença significativa } \\
\text { de áreas florestadas, } \\
\text { com a presença de } \\
\text { vegetação nativa. } \\
\text {-Acesso, em algumas } \\
\text { propriedades, } \\
\text { dificultado pelo relevo } \\
\text { inclinado. } \\
\text {-Presença de áreas } \\
\text { ocupadas pelas } \\
\text { culturas (milho, trigo e } \\
\text { fumo) pastagens para } \\
\text { a alimentação do gado. }\end{array}$ & 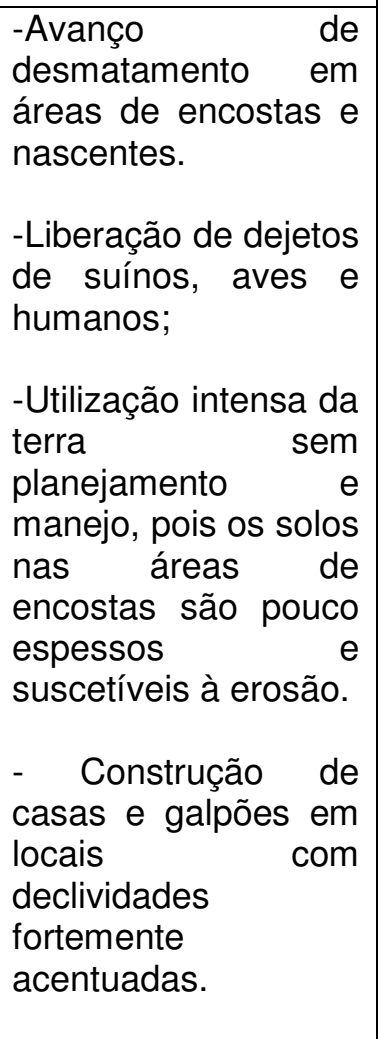 & 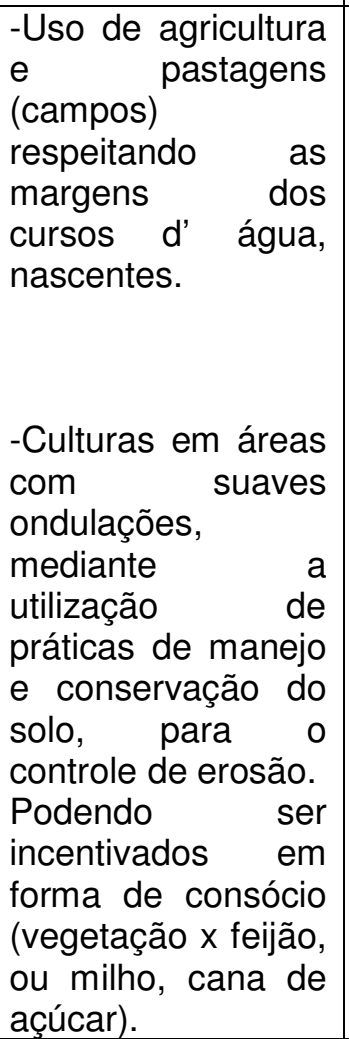 & $\begin{array}{l}\text {-Industrialização da } \\
\text { madeira; } \\
\text { produção de alimentos } \\
\text { (mel, peixes, fruticultura, } \\
\text { horticultura); } \\
\text {-Agroecologia. } \\
\text {-Conservação do solo. } \\
\text {-Habitação. } \\
\text {-Mini-indústria do leite } \\
\text { (produção de manteiga, } \\
\text { iogurte, queijos, nata, doce } \\
\text { de leite, requeijão entre } \\
\text { outros). } \\
\text {-Gado de leite. }\end{array}$ & $\begin{array}{l}\text {-Processamento } \\
\text { artesanal de produtos } \\
\text { (mel e frutas) } \\
\text {-Ampliação de áreas } \\
\text { florestadas, incluindo } \\
\text { espécies frutíferas. } \\
\text { Construção de casas e } \\
\text { galpões em áreas } \\
\text { planejadas, orientadas } \\
\text { pela legislação. }\end{array}$ \\
\hline
\end{tabular}


A partir das idéias levantadas pela população nos projetos voltados da microbacia, pode-se orientar algumas ações face às características ambientais existentes. No que se referem às áreas florestadas, estas podem e devem ser ampliadas no sentido de aumentar a própria biodiversidade do sistema e a dinâmica econômica, pois espécies frutíferas são recomendadas juntamente com outras espécies nativas e também em sistema de consórcio com a produção de arroz, feijão, mandioca, entre outros.

A instalação de agroindústrias para o processamento de produtos como o mel, leite, laranja, etc., também são favorecidos, pois o relevo plano a suavemente ondulado contribui para a localização e a instalação das mesmas, e o acesso possibilita o escoamento da produção de forma mais rápida até o mercado consumidor.

A sede comunitária é um espaço onde o lazer pode ser usufruído de forma saudável. Não menos importante é destacar que nesse espaço também podem ser orientados e oferecidos cursos que atendam a demanda da comunidade local, como cursos (de artesanato, bordado, culinária, manicure, entre outros), envolvendo não só as senhoras, mães de famílias, mas as jovens que ainda permanecem em casa, mostrando que existem inúmeras oportunidades para a dinamização da economia, definida aqui como uma atividade não agrícola.

No que se refere à atividade de gado de leite e de corte, em menor proporção, é praticada em todas as propriedades da microbacia, em todas as zonas homogêneas delimitadas. A tarefa de lidar com o gado de leite têm crescido nos últimos anos face ao abandono ou a diminuição das atividades de criação de suínos. Os preços pagos pelo litro do leite, no momento, é um incentivo para se manter na atividade. Para tal, são usadas áreas não somente planas, mas de encostas, para o cultivo da pastagem que serve de alimento para o gado, principalmente durante 0 período de inverno.

Nesse sentido, chama-se a atenção para a qualificação dos produtores, para que estes melhorem a pastagem, mantenham um plantel de gado com raças adequadas às características das propriedades.

As práticas de conservação do solo devem ser incentivadas por inúmeras razões, entre elas pode-se citar: a melhoria na qualidade dos nutrientes que existem no solo; diminuição dos níveis de erosão; aumento na produtividade e na qualidade dos produtos. As informações podem ser visualizadas no Quadro 11 a seguir. 
Quadro 11 - Proposta de Zoneamento-Antrópico-Ambiental para a ZUOC na microbacia hidrográfica do Lajeado Pirapó-Iporã do Oeste-SC

\begin{tabular}{|c|c|c|c|c|c|}
\hline Zonas & Cenário atual & Usos proibidos & Tolerados & $\begin{array}{l}\text { Projetos levantados e } \\
\text { desejados pela } \\
\text { população para toda } \\
\text { a microbacia }\end{array}$ & $\begin{array}{l}\text { Cenário projetado e a } \\
\text { incentivar na ZUOC. }\end{array}$ \\
\hline ZUOC & $\begin{array}{l}\text {-Esta área apresenta um } \\
\text { relevo suave ondulado, } \\
\text { com solos ricos em } \\
\text { matéria orgânica (fundo } \\
\text { de vale). } \\
\text { - Acesso principal do } \\
\text { interior da microbacia em } \\
\text { bom estado de } \\
\text { conservação. } \\
\text {-Presença de áreas } \\
\text { ocupadas pelas culturas } \\
\text { (milho, feijão e fumo) } \\
\text { pastagens para a } \\
\text { alimentação do gado. } \\
\text { Localização da sede da } \\
\text { comunidade (igreja e } \\
\text { salão de festas). } \\
\text { Presença da (CASAN) } \\
\text { sub-estação de } \\
\text { tratamento de água. }\end{array}$ & 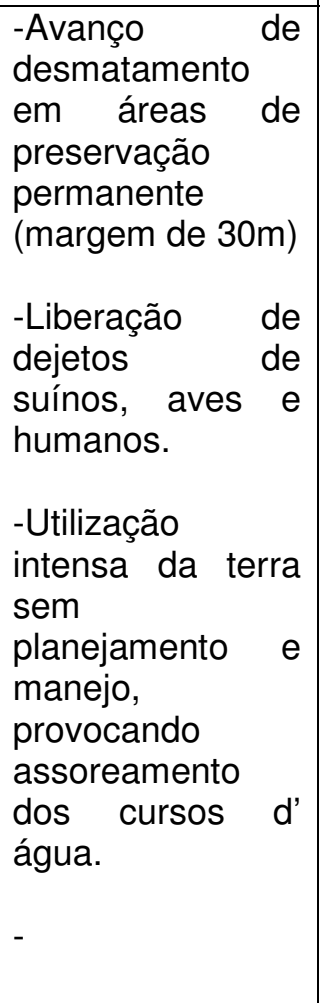 & 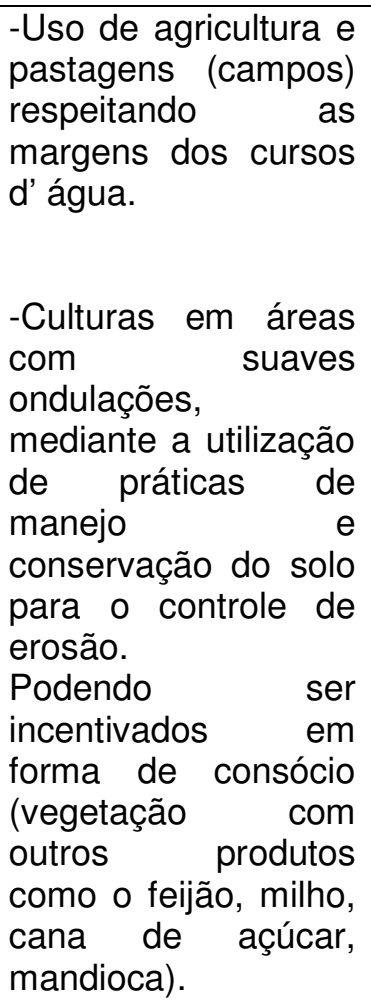 & $\begin{array}{l}\text {-Agroecologia. } \\
\text {-Conservação do solo. } \\
\text {-Habitação. } \\
\text {-Mini-indústria do leite } \\
\text { (produção de } \\
\text { manteiga, iogurte, } \\
\text { queijos, nata, doce de } \\
\text { leite, requeijão entre } \\
\text { outros). } \\
\text {-Gado de leite. }\end{array}$ & 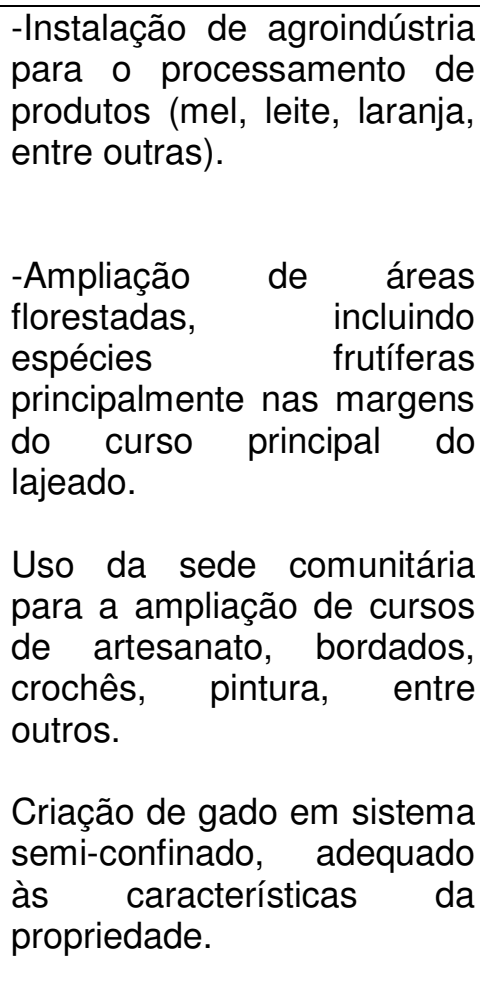 \\
\hline
\end{tabular}




\subsection{2 - Zoneamento-Antrópico-Ambiental da microbacia hidrográfica do Lajeado Esperança}

A partir do zoneamento elaborado para a microbacia hidrográfica do Lajeado Pirapó, buscou-se trabalhar na mesma dinâmica com a microbacia do Lajeado Esperança. Assim, as zonas homogêneas definidas e adotadas são as mesmas para a referida microbacia, conforme mostra a Figura 32 e Tabela 11. Nesse contexto, é importante destacar que nesta microbacia a dinâmica de distribuição espacial das zonas se mostrou, um pouco diferenciada, pelas características do relevo e hipsométricas, principalmente.

Percebe-se que as zonas tiveram uma distribuição sem muitas variações em ha, ressaltando que a ZUOR abrange uma área de $41,96 \%$ da microbacia.

Tabela 11 - Zonas homogêneas delimitadas na microbacia hidrográfica do Lajeado Esperança, Município de Iporã do Oeste-SC.

\begin{tabular}{lccc}
\hline \multicolumn{1}{c}{ ZONAS } & ha & $\%$ \\
\hline ZUOM & Zona de Uso e Ocupação Moderada & 761,94 & 26,98 \\
ZUOR & Zona de Uso Ocupaçâo Restrita & $1.184,92$ & 41,96 \\
ZUOC & Zona de Uso e Ocupação Controlada & 876,99 & 31,06 \\
\hline TOTAL & & $2.823,85$ & 100 \\
\hline
\end{tabular}

Organização: Rosangela L. Spironello, Out/2007.

A ZUOM encontra-se localizada na porção leste da microbacia, abrangendo as declividades de $<5 \%$ a $30 \%$, com uma variação altimétrica aproximada que se estende de $240 \mathrm{~m}$ a $360 \mathrm{~m}$. Face a configuração topográfica alternada (áreas planas e suave ondulada) pode-se verificar a presença de solos como Latossolos, Cambissolos e Gleissolos (PUNDEK E MOLINARI, 2001). Nas adjacências onde o curso principal do Lajeado Esperança encontra o Rio das Antas, tem-se uma concentração maior de solos Gleissolos. Por se constituir uma área plana, ocorre a deposição de sedimentos, contribuindo para a formação de matéria orgânica nessa porção do espaço. Por outro lado, a intensa utilização do local pelas atividades agrícolas favorece a intensificação dos níveis de erosão e, principalmente, o assoreamento dos cursos d' água. 


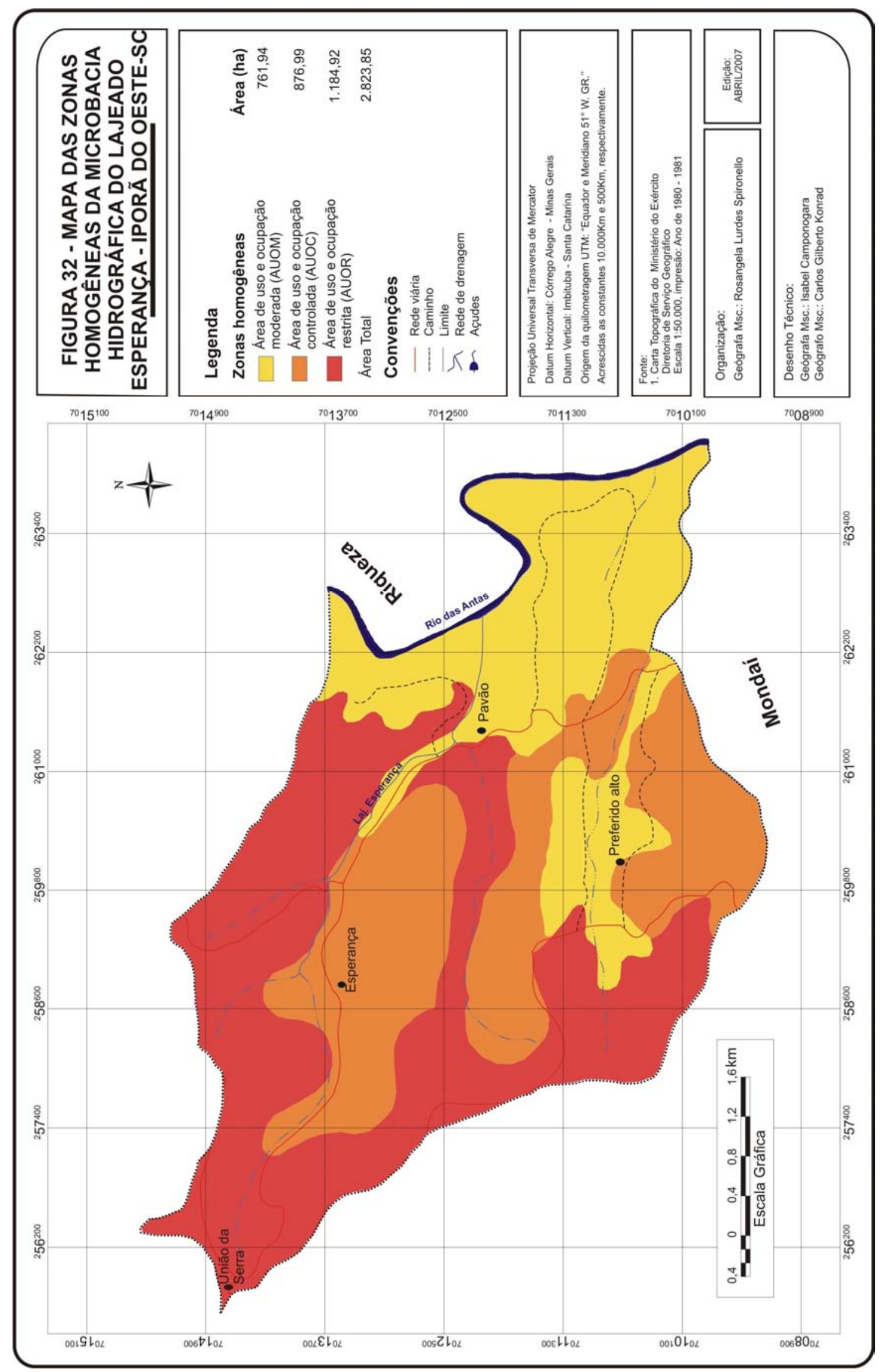


No que se refere ao uso da terra, nesta zona tem-se a predominância do uso da terra culturas, com a produção principalmente de milho e fumo. Ocorre também a presença de alguns fragmentos de vegetação nativa como o cedro e o angico, e vegetação secundária como capoeirões, face ao abandono de algumas propriedades.

Por outro lado, as limitações de uso também se fazem presentes nessa porção; a utilização de agrotóxicos nas lavouras é uma constante. O uso abusivo de defensivos agrícolas pode causar sérias doenças nas pessoas que aplicam o produto e nas que se encontram nas adjacências, pois acabam por inalar o cheiro desses produtos, trazidos pela movimentação do ar e por consumir a água, contaminada.

Presencia-se nessa porção níveis acentuados de desmatamento, reflexo do processo de ocupação histórica, pois de acordo com os mapeamentos efetuados e já discutidos anteriormente, nesta porção as áreas de mata foram extraídas desde o princípio, abrindo com isso, novos espaços para o avanço da agricultura.

A ZUOM na microbacia hidrográfica do Lajeado Esperança pode ser observada no Quadro 12.

A Zona de Uso e Ocupação Controlada (ZUOC) distribui-se nas porções oeste-centro da microbacia, faixa central entre a ZUOR e ZUOM e porção sul, próximo à comunidade da Linha Preferido Alto. Esta zona ocupa áreas com relevo suave ondulado a ondulado, com declividades que podem alcançar até $30 \%$. As altitudes variam de aproximadamente $300 \mathrm{~m}$ a $420 \mathrm{~m}$ em algumas áreas. Os solos caracterizados são os Latossolos, com pouca expressividade, e os Cambissolos, de acordo com os dados de Pundek e Molinari (2001).

Como potencialidade nesta zona, tem-se a presença do cultivo de cana-deaçúcar (em pequenas áreas) para a produção do açúcar de cana, melado e cachaça, os quais são consumidos pelas próprias famílias de agricultores.

Ocorre a presença bem significativa da produção de milho e fumo. Identifica-se também o sistema de parceria com empresas agroindustriais como a Cargill e Aurora com a criação de aves. Os galpões que abrigam as aves, localizamse principalmente ao longo da estrada que dá acesso às comunidades na microbacia. 
Quadro12 - Caracterização da zona de uso e ocupação moderada na microbacia hidrográfica do Lajeado Esperança - Iporã do Oeste-SC.

\begin{tabular}{|c|c|c|c|c|c|}
\hline Zonas & Caracterização & Potencialidades & Limitações & $\begin{array}{l}\text { Aspectos } \\
\text { socioeconômicos } \\
\text { (uso da terra) }\end{array}$ & $\begin{array}{l}\text { Principais problemas } \\
\text { ambientais (conflitos } \\
\text { ambientais) }\end{array}$ \\
\hline \multirow[t]{5}{*}{ ZUOM } & $\begin{array}{l}\text { Corresponde a de } \\
\text { baixas altitudes }\end{array}$ & $\begin{array}{l}\text { Predomina o relevo } \\
\text { plano com suaves } \\
\text { ondulações. }\end{array}$ & $\begin{array}{l}\text { Utilização } \\
\text { agrotóxicos, } \\
\text { contaminando o solo e } \\
\text { os recursos hídricos. }\end{array}$ & $\begin{array}{l}\text { Distribuição } \text { da } \\
\text { população de forma } \\
\text { dispersa. }\end{array}$ & $\begin{array}{l}\text { Desmatamento nas } \\
\text { margens dos cursos d' } \\
\text { água do Lajeado e do } \\
\text { Rio das Antas. }\end{array}$ \\
\hline & $\begin{array}{l}\text { Pequenas } \\
\text { propriedades e } \\
\text { predominância da } \\
\text { mão de obra familiar. }\end{array}$ & $\begin{array}{l}\text { Atividades econômicas } \\
\text { predominantes } \\
\text { área: culturas (milho, } \\
\text { feijão e fumo). }\end{array}$ & $\begin{array}{l}\text { Uso de agricultura e } \\
\text { pastagens (campos) nas } \\
\text { margens dos cursos d' } \\
\text { água. }\end{array}$ & $\begin{array}{l}\text { Utilização de mão- } \\
\text { de-obra } \\
\text { predominantemente } \\
\text { familiar. }\end{array}$ & $\begin{array}{l}\text { Poluição dos cursos d' } \\
\text { água por agrotóxicos. }\end{array}$ \\
\hline & $\begin{array}{l}\text { Produção agrícola } \\
\text { (milho, fumo e feijão) } \\
\text { voltada ao comércio } \\
\text { e a subsistência das } \\
\text { famílias. }\end{array}$ & 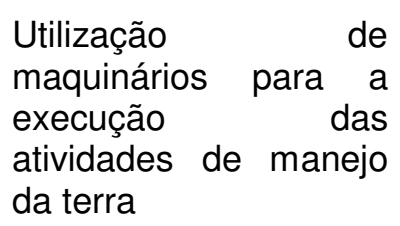 & $\begin{array}{l}\text { Solos argilosos nas } \\
\text { margens limítrofes com o } \\
\text { Rio das Antas. }\end{array}$ & $\begin{array}{l}\text { Predominância da } \\
\text { produção de milho, } \\
\text { feijão e fumo. }\end{array}$ & Queimadas. \\
\hline & $\begin{array}{l}\text { Área que limita-se } \\
\text { com o Município de } \\
\text { Riqueza, através do } \\
\text { Rio das Antas. }\end{array}$ & $\begin{array}{l}\text { Solo rico em matéria } \\
\text { orgânica. }\end{array}$ & $\begin{array}{l}\text { Assoreamento do curso } \\
\text { d'água. }\end{array}$ & & \\
\hline & $\begin{array}{l}\text { Presença de } \\
\text { vegetação distribuída } \\
\text { de forma esparsa. }\end{array}$ & & $\begin{array}{l}\text { Distância da área } \\
\text { urbana. }\end{array}$ & & \\
\hline
\end{tabular}


Os agrotóxicos, como nas outras zonas, também são utilizados, sendo uma prática normal nas propriedades, conforme informações obtidas in loco e no próprio relatório já apresentado anteriormente.

A utilização de áreas para as pastagens é significativa, face a atividade voltada a produção de leite, a qual requer espaço e alimento para o gado, principalmente nas épocas de inverno. Porém, tais espaços são usados por alguns agricultores de forma inadequada, como próximos às margens dos afluentes e em encostas, favorecendo os índices de erosão e assoreamento dos cursos d' água.

A utilização de mão-de-obra é essencialmente familiar, salvo algumas exceções de contratações de terceiros para a execução de algumas atividades que requerem o uso de maquinários, como tratores para o plantio e até mesmo para lançar os defensivos nas culturas de milho, por exemplo.

Eventualmente também é contratada mão de obra para trabalhar em aviários durante a permanência do lote de frangos, bem como para o desbaste do fumo e/ou colheita do mesmo. Essa mão-de-obra normalmente é de jovens que moram com os familiares e que vêem na agricultura um meio de permanência e até mesmo de sobrevivência. O Quadro 13 nos mostra a caracterização da Zona Uso e Ocupação Controlada (ZUOC), na área de estudo.

No que se refere à ZUOR - Zona de Uso e Ocupação Restrita, esta encontra-se localizada na porção norte-oeste e oeste-sul da microbacia hidrográfica do Lajeado Esperança, nos divisores de água, estendendo-se por uma faixa até a porção central do Lajeado. As declividades nessa zona são superiores a $30 \%$ e > $47 \%$, com o predomínio do relevo com características de ondulado a fortemente ondulado. As altitudes variam de aproximadamente, de $420 \mathrm{~m}$ a $500 \mathrm{~m}$, abrangendo a maior parte das nascentes, e os vales se apresentam com vertentes íngremes e dissecadas. Pelo Código Florestal, é uma área na sua maioria considerada de conservação permanente.

Conforme destaca Pundek e Molinari (2001), os tipos de solos identificados nessa porção são os Latossolos, principalmente em topos de moros, Cambissolos e - Nitossolos, rasos, com a presença de pedregulhos e alguns afloramentos rochosos. Essa característica, favorece o risco de erosão das áreas de encostas, face a inexpressiva quantidade de vegetação em alguns pontos e ao uso intensivo da terra para as práticas de agricultura e pastagem, com a presença de potreiros. 
Quadro13 - Caracterização da zona de uso e ocupação controlada na microbacia hidrográfica do Lajeado Esperança - Iporã do Oeste-SC.

\begin{tabular}{|c|c|c|c|c|c|}
\hline Zonas & Caracterização & Potencialidades & Limitações & $\begin{array}{l}\text { Aspectos } \\
\text { socioeconômicos } \\
\text { (uso da terra) }\end{array}$ & $\begin{array}{l}\text { Principais problemas } \\
\text { ambientais (conflitos } \\
\text { ambientais) }\end{array}$ \\
\hline ZUOC & 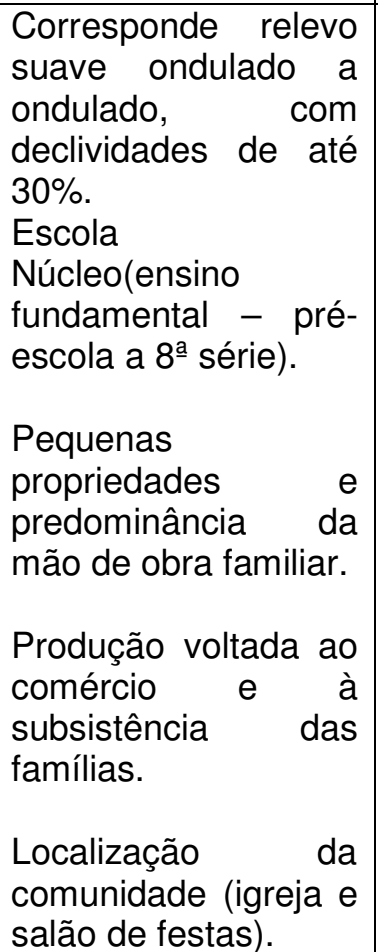 & 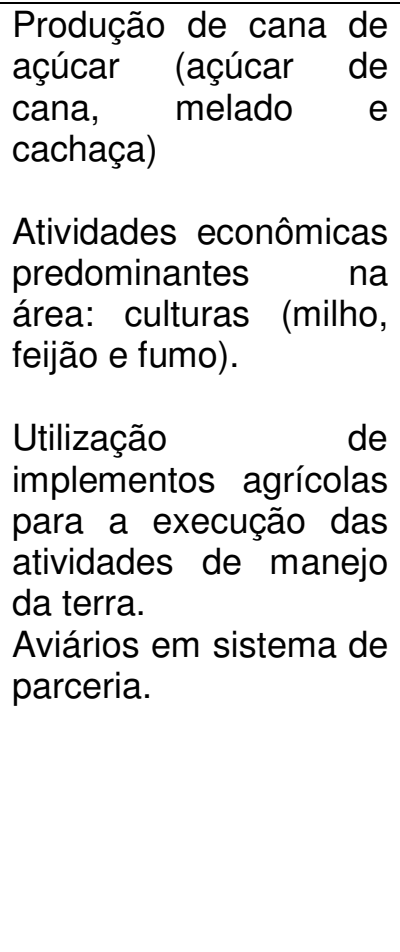 & $\begin{array}{l}\text { Utilização de } \\
\text { agrotóxicos. } \\
\text { Uso de agricultura e } \\
\text { pastagens (campos) nas } \\
\text { margens dos cursos d' } \\
\text { água. } \\
\text { Potreiros nas áreas de } \\
\text { relevo ondulado, } \\
\text { favorecendo os níveis de } \\
\text { erosão e sulcos. } \\
\text { Assoreamento do curso } \\
\text { d'água. }\end{array}$ & $\begin{array}{l}\text { Distribuição da } \\
\text { população de forma } \\
\text { dispersa. } \\
\text { Utilização de mão de } \\
\text { obra } \\
\text { predominantemente } \\
\text { familiar. } \\
\text { Predominância da } \\
\text { produção de milho, } \\
\text { feijão e fumo. } \\
\text { Gado de leite em } \\
\text { sistema extensivo. }\end{array}$ & $\begin{array}{l}\text { Desmatamento nas } \\
\text { áreas de encostas. } \\
\text { Poluição dos cursos d' } \\
\text { água por agrotóxicos e } \\
\text { dejetos (suínos e aves). } \\
\text { Erosão e sulcos. }\end{array}$ \\
\hline
\end{tabular}


Com base nisso, pode-se inferir que esta área apresenta um potencial de conflitos bem significativo e pode se agravar caso seja utilizada de forma inadequada, comprometendo toda a estrutura das propriedades que são abrangidas por ela.

Percebe-se também que nesta porção encontram-se áreas campo (potreiros), destinadas à criação de gado, os quais contribuem para a compactação do solo com o pisoteio, aumentando os índices de erosão e vulnerabilidade dessas áreas, sem falar da possibilidade do surgimento de áreas de voçorocamento.

Outros problemas foram identificados como nas demais zonas delimitadas, como, o uso intensivo de agrotóxicos, desmatamento, uso das áreas para cultivo até à margem dos cursos d’água. A porção dentro desta zona que mais apresenta conflitos de uso localiza-se no setor sul-oeste da microbacia e uma faixa que abrange a porção central.

Tem-se a utilização da mão de obra familiar, destacando as tarefas desenvolvidas com a atividade leiteira, suínos, aves, bem como na produção de milho e fumo. Nessa zona ocorre também a presença de açudes, os quais servem para a criação de peixes e até mesmo para a dessedentação dos animais. No Quadro 14 são apresentadas as características da ZUOR para a microbacia do Lajeado Esperança.

5.3.2.1 Zonas homogêneas $X$ perspectivas da população na microbacia do Lajeado Esperança

Para a microbacia hidrográfica do Lajeado Esperança desenvolveu-se a mesma dinâmica de análise e discussão utilizada para a microbacia do Lajeado Pirapó, no que se refere a proposição das zonas homogêneas e perspectivas da população.

Dessa forma, considerou-se os projetos que a população inserida na área de estudo elencou como prioridades a serem implantadas, face a necessidade e a realidade existente. 
Quadro 14 - Caracterização da zona de uso e ocupação restrita na microbacia hidrográfica do Lajeado Esperança - Iporã do Oeste-SC.

\begin{tabular}{|c|c|c|c|c|c|}
\hline Zonas & Caracterização & Potencialidades & Limitações & $\begin{array}{l}\text { Aspectos } \\
\text { socioeconômicos } \\
\text { (uso da terra) }\end{array}$ & $\begin{array}{l}\text { Principais problemas } \\
\text { ambientais (conflitos } \\
\text { ambientais) }\end{array}$ \\
\hline \multirow[t]{4}{*}{ ZUOR } & $\begin{array}{l}\text { Apresenta um relevo } \\
\text { ondulado, } \\
\text { fortemente ondulado, } \\
\text { com a presença de } \\
\text { áreas } \\
\text { preservação } \\
\text { conservação } \\
\text { permanente. }\end{array}$ & $\begin{array}{l}\text { Presença de áreas de } \\
\text { pastagens e açudes. }\end{array}$ & $\begin{array}{l}\text { Potreiros nas áreas de } \\
\text { relevo ondulado, a } \\
\text { fortemente ondulado } \\
\text { compactando o solo e } \\
\text { favorecendo os níveis de } \\
\text { erosão. }\end{array}$ & $\begin{array}{l}\text { Distribuição da } \\
\text { população de forma } \\
\text { dispersa. }\end{array}$ & $\begin{array}{ll} & \text { Desmatamento } \\
\text { áreas de encostas e ao } \\
\text { longo dos cursos } \\
\text { d'água.. }\end{array}$ \\
\hline & $\begin{array}{lr}\text { Localização } & \text { da } \\
\text { comunidade } & \text { (igreja), } \\
\text { comunidade } & \text { de } \\
\text { União da Serra } & \end{array}$ & $\begin{array}{l}\text { Atividades econômicas } \\
\text { predominantes } \\
\text { área: culturas (milho, } \\
\text { feijão e fumo). }\end{array}$ & $\begin{array}{l}\text { Uso de agricultura e } \\
\text { pastagens (campos), } \\
\text { próximos as nascentes e } \\
\text { nas margens dos cursos } \\
\text { d'áqua. }\end{array}$ & $\begin{array}{l}\text { Utilização de mão de } \\
\text { obra } \\
\text { predominantemente } \\
\text { familiar }\end{array}$ & $\begin{array}{l}\text { Poluição dos cursos d' } \\
\text { água por agrotóxicos e } \\
\text { dejetos (suínos e aves) }\end{array}$ \\
\hline & $\begin{array}{l}\text { Pequenas } \\
\text { propriedades e } \\
\text { predominância da } \\
\text { mão de obra familiar. }\end{array}$ & $\begin{array}{l}\text { Chiqueiros e avários } \\
\text { em sistema de } \\
\text { parceria. }\end{array}$ & $\begin{array}{ll}\text { Utilização } & \text { de } \\
\text { agrotóxicos. } & \end{array}$ & $\begin{array}{l}\text { Predominância da } \\
\text { produção de milho, } \\
\text { feijão e fumo. }\end{array}$ & Erosão e sulcos. \\
\hline & $\begin{array}{l}\text { Agricultura (milho e } \\
\text { fumo) criação de } \\
\text { sinos e aves. }\end{array}$ & & $\begin{array}{l}\text { Utilização de } \\
\text { implementos agrícolas } \\
\text { para a execução das } \\
\text { atividades de manejo da } \\
\text { terra e áreas de } \\
\text { encostas }\end{array}$ & $\begin{array}{lr}\text { Gado de leite em } & \text { em } \\
\text { sistema } & \text { extensivo; } \\
\text { parceria } & \text { com } \\
\text { empresas } & \text { na } \\
\text { produção de aves e } \\
\text { suínos. }\end{array}$ & \\
\hline
\end{tabular}


O cenário atual e desejado foi elaborado num contexto geral, considerado os aspectos socioeconômicos e ambientais, da área de estudo, porém não perdendo o foco da inserção de cada zona, com as atividades sugeridas, na dinâmica de produção e de consumo espacial local e regional. Toa essa dinâmica, da ZUOM encontra-se estruturado no Quadro 15.

$\mathrm{Na}$ ZUOM, o cenário atual caracterizado é de uma área com relevo suave a ondulado, com a presença de áreas destinadas às atividades de produção de milho e fumo, principalmente, com pastagens para a alimentação do gado.

A mão-de-obra empregada nas atividades é essencialmente familiar, apresentando uma distribuição da população de forma dispersa.

Esta zona limita-se na porção leste da microbacia, distando aproximadamente, $20 \mathrm{~km}$ da área urbana da cidade. Para a população a distância dificulta o acesso às oportunidades, que muitas vezes chegam ao conhecimento somente pelos meios de comunicação (rádio).

A utilização da terra se dá de forma intensa, com a prática de cultivos e com o uso de agrotóxicos, prática não recomendada face às conseqüências que podem trazer a toda a população e também aos recursos naturais.

Nessa porção é tolerado o uso da agricultura e de pastagens para a alimentação do gado, porém respeitando as margens dos cursos d’água. As práticas de manejo devem estar acompanhas a atividades voltadas a produção de produtos agrícolas, evitando assim, o surgimento de focos de erosão de sulcos ou laminar.

O sistema de consórcio pode ser incentivado, com a vegetação, e a produção de milho, feijão, cana de açúcar, mandioca, entre outros. Um sistema utilizado é a plantação de espécies frutíferas consorciado com o feijão, a mandioca, e aveia, neste caso, para a alimentação do gado.

Para tal, dos projetos elencados pela população para a microbacia hidrográfica do Lajeado Esperança tem-se os seguintes: a população visualiza a implantação de mini-agroindústrias para o processamento da matéria prima, como as frutas, dentre elas pode-se citar: a laranja, o pêssego e a uva. O gado também é uma das atividades que a população considera rentável e possível de ser ampliada. Contudo, observa-se que o planejamento da atividade e o manejo adequado do solo e das pastagens contribuem para a manutenção da qualidade ambiental do espaço como um todo. 
Quadro 15 - Proposta de Zoneamento-Antrópico-Ambiental para a ZUOM na microbacia hidrográfica do Lajeado Esperança-Iporã do Oeste-SC.

\begin{tabular}{|c|c|c|c|c|c|}
\hline Zonas & Cenário atual & Usos proibidos & Tolerados & $\begin{array}{l}\text { Projetos levantados e } \\
\text { desejados pela } \\
\text { população para toda } \\
\text { a microbacia }\end{array}$ & $\begin{array}{l}\text { Cenário projetado e a } \\
\text { incentivar na ZUOM. }\end{array}$ \\
\hline ZUOM & $\begin{array}{l}\text {-A área se mostra com } \\
\text { um relevo suave a } \\
\text { ondulado. } \\
\text { - Área limítrofe com o } \\
\text { Município de Riqueza. } \\
\text {-Presença de áreas } \\
\text { ocupadas pelas culturas } \\
\text { (milho, feijão e fumo) } \\
\text { pastagens para a } \\
\text { alimentação do gado. } \\
\text {-Uso da terra intenso } \\
\text { com atividades voltadas } \\
\text { a produção de milho, } \\
\text { fumo e pastagens para o } \\
\text { gado. } \\
\text { - Mão de obra familiar. } \\
\text {-Área distante do centro } \\
\text { urbano. }\end{array}$ & $\begin{array}{l}\text {-Avanço de } \\
\text { desmatamento } \\
\text { em áreas de } \\
\text { preservação } \\
\text { permanente } \\
\text { (margem de } 30 \\
\text { m), } \\
\text { principalmente na } \\
\text { margem do Rio } \\
\text { das Antas. } \\
\text {-Utilização } \\
\text { intensa da terra } \\
\text { sem } \\
\text { planejamento e } \\
\text { manejo, } \\
\text { provocando } \\
\text { assoreamento } \\
\text { dos cursos d' } \\
\text { água. } \\
\text { Uso de } \\
\text { agrotóxicos. }\end{array}$ & 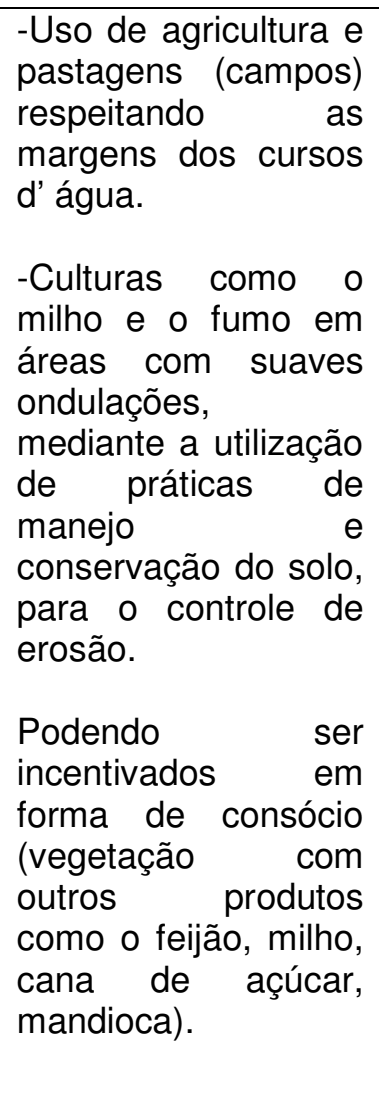 & $\begin{array}{l}\text { - Fruticultura. } \\
\text {-Produção orgânica. } \\
\text {-Conservação do solo. } \\
\text {-Habitação. } \\
\text {-Mini-indústria de } \\
\text { sucos concentrados. } \\
\text {-Gado de leite. } \\
\text {-Recuperação } \\
\text { manejo de florestas e } \\
\text { nascentes. } \\
\text {-Coleta seletiva do lixo. } \\
\text { Associação de } \\
\text { produtores. }\end{array}$ & $\begin{array}{l}\text {-Instalação } \\
\text { agroindústria para o } \\
\text { processamento de } \\
\text { produtos (mel, leite, } \\
\text { laranja, entre outras). } \\
\text {-Ampliação de áreas } \\
\text { florestadas incluindo } \\
\text { espécies frutíferas } \\
\text { principalmente nas } \\
\text { margens do curso } \\
\text { principal do Lajeado do } \\
\text { Rio das Antas. } \\
\text {-Coleta seletiva de lixo. } \\
\text {-Criação de gado com } \\
\text { sistema de manejo } \\
\text { adequado. } \\
\text {-Sistema de parcerias } \\
\text { entre produtores. } \\
\text {-Produção de alimentos } \\
\text { orgânicos. }\end{array}$ \\
\hline
\end{tabular}


A recuperação e manejo florestal também fazem parte dos projetos prioritários. Pelo mapeamento do uso da terra, têm-se poucas áreas florestadas, com alguns fragmentos distribuídos de forma heterogênea pelo espaço. Com base nisso, reforça-se a necessidade de implantação desse projeto não visando somente o aumento da biodiversidade, mas inclusive visando à manutenção das pessoas nesses espaços, com maior qualidade ambiental.

Hoje percebe-se que as pessoas estão se mostrando mais propícias a mudança de comportamento, pelo menos no que diz respeito a manutenção de áreas florestadas. Essa mudança de comportamento veio a tona principalmente porque as famílias residentes nessa zona e nas demais da microbacia, pelo fato de conviverem, praticamente todo $\mathrm{o}$ ano com períodos de estiagem. Em conversa informal com alguns proprietários, os mesmos destacaram que a vegetação é fundamental para a manutenção da umidade do solo e dos recursos hídricos.

No que se refere à questão da habitação, este também é um projeto que deve ser incentivado, porque primeiramente, vem de encontro a uma necessidade social, a qual proporciona um aumento da auto-estima nas pessoas e as incentiva a permanecer naquele lugar, onde possivelmente já tenha uma história de vida construída. Em segundo lugar, porque as condições físicas favorecem a construção de bem-feitorias sem maiores restrições. Esse tipo de projeto também pode estar atrelado ao melhoramento dos acessos a algumas propriedades, visando o deslocamento das pessoas e dos produtos ao mercado consumidor.

A produção orgânica é outra alternativa vislumbrada pela comunidade local, visto que as condições de relevo, microclima, entre outras são favoráveis. Entretanto, diante da realidade que é presenciada, não somente nessa zona, mas em todo território do município, a utilização de agrotóxicos ainda é uma prática presente. Para implantar este tipo de produção, é necessário que a população se conscientize e mude seus hábitos, pois não existe produto orgânico numa propriedade, se nas adjacências essa prática é intensiva. Portanto, essa atividade exige que se faça uma tomada de consciência e que o comprometimento e o envolvimento sejam de todos, pois isso só será possível com a mudança de comportamento por parte de todas as pessoas, estejam elas envolvidas direta ou indiretamente com a questão.

Projetos voltados à conservação do solo também são prioridades, pois como as áreas são intensamente utilizadas pelas atividades agrícolas, o desgaste 
do solo também é significativo. Sugere-se com isso, que a população busque orientação adequada com técnicos e façam planejamento de uso e manejo do solo, para que este possibilite uma maior produção sem perder seus nutrientes nos processos erosivos.

A coleta seletiva do lixo deve ser incentiva por ser extremamente positiva, no que diz respeito ao meio ambiente, face aos reflexos que pode causar num determinado espaço se não forem tomadas medidas preventivas, principalmente no que diz respeito às embalagens de agrotóxicos, que devem ser devolvidas as empresas habilitadas para que seja dado o destino final ao produto. Outros tipos de lixo já vêm sendo recolhidos (sucatas, ferro, latas, alumínios), os quais são conduzidos a locais próprios para a seleção e reaproveitamento.

Uma dinâmica pouco comum nos dias de hoje é o trabalho em sistema de associações, impossibilitado, muitas vezes em função do próprio sistema ao qual a sociedade encontra-se inserida. No intuito de agregar valor aos produtos produzidos e buscar a própria inserção no mercado de produção, os agricultores projetam formar grupos visando desenvolver determinadas atividades. Esse tipo de parceria contribui para a dinamização da produção, troca de experiências, na valorização do produto final, uma vez que o mercado hoje exige que se forneça um produto de qualidade e em quantidade significativa para a demanda de consumo. Um exemplo disso é a produção de leite, cada produtor busca em sua propriedade melhorar o plantel, o manejo, alimentação e higiene local para agregar mais valor ao produto. Assim, a venda é feita em conjunto, onde se reúnem três ou quatro famílias, dependendo do tamanho do plantel, com uma única inscrição nos laticínios. Dessa forma, o valor do litro do leite pago é maior do que se o agricultor vendesse de forma individual.

No que se refere a ZUOR, o cenário atual que se apresenta é de áreas com relevos declivosos, abrangendo porções destinadas à preservação e a conservação permanente, de acordo com o Código Florestal Brasileiro. Em alguns pontos ocorre a dificuldade de acesso às propriedades, devida a inclinação do relevo.

Da mesma forma, como nas demais zonas delimitadas, tem-se a mão-deobra familiar predominando e as atividades voltadas à produção de milho e fumo são significativas. As informações podem ser observadas no Quadro 16. 
Quadro 16 -Proposta de Zoneamento-Antrópico-Ambiental para a ZUOR na microbacia hidrográfica do Lajeado Esperança-Iporã do Oeste-SC.

\begin{tabular}{|c|c|c|c|c|c|}
\hline Zonas & Cenário atual & Usos proibidos & Tolerados & $\begin{array}{l}\text { Projetos levantados e } \\
\text { desejados pela população } \\
\text { para toda a microbacia }\end{array}$ & $\begin{array}{l}\text { Cenário projetado e a } \\
\text { incentivar na ZUOR. }\end{array}$ \\
\hline ZUOR & $\begin{array}{l}\text { - Conta com um relevo } \\
\text { ondulado, com fortes } \\
\text { declives, abrangendo em } \\
\text { maior proporção áreas } \\
\text { de ACP e APP. } \\
\text { - Localização da } \\
\text { comunidade de Linha } \\
\text { União da Serra, na } \\
\text { porção noroeste da } \\
\text { microbacia. } \\
\text {-Dificuldade de acesso a } \\
\text { algumas propriedades } \\
\text { em função do relevo } \\
\text { inclinado. } \\
\text {-Presença de áreas } \\
\text { ocupadas pelas culturas } \\
\text { (milho e fumo) pastagens } \\
\text { (alimentação do gado), } \\
\text { criação de aves e } \\
\text { suínos. } \\
\text { Pequenas propriedades - } \\
\text { mão de obra familiar }\end{array}$ & 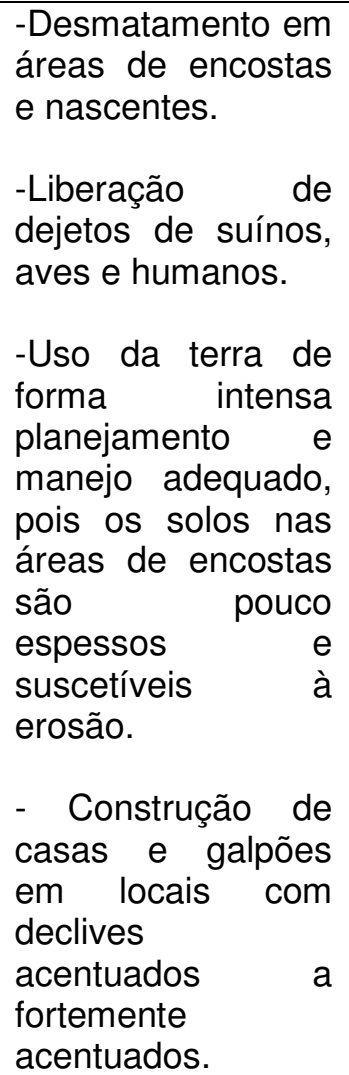 & 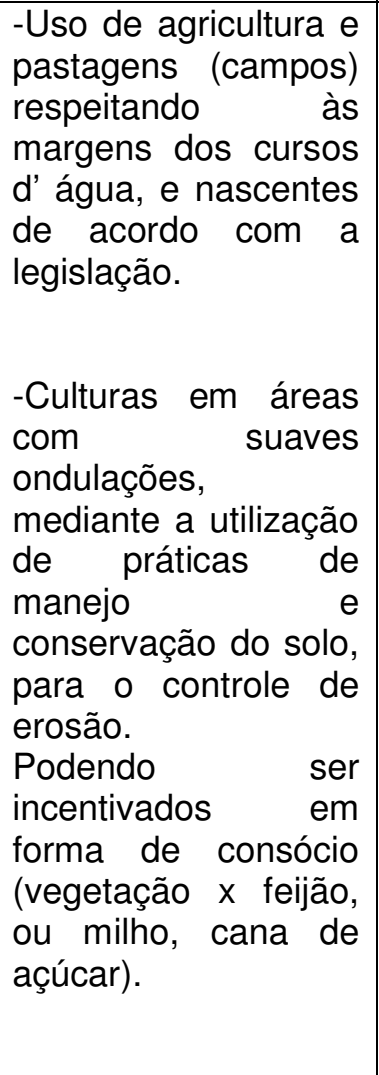 & $\begin{array}{l}\text { - -Fruticultura. } \\
\text {-Produção orgânica. } \\
\text {-Conservação do solo } \\
\text {-Habitação. } \\
\text {-Mini-indústria de sucos } \\
\text { concentrados. } \\
\text {-Gado de leite. } \\
\text {-Recuperação e manejo de } \\
\text { florestas e nascentes. } \\
\text {-Coleta seletiva do lixo. } \\
\text { - Associação de produtores. }\end{array}$ & 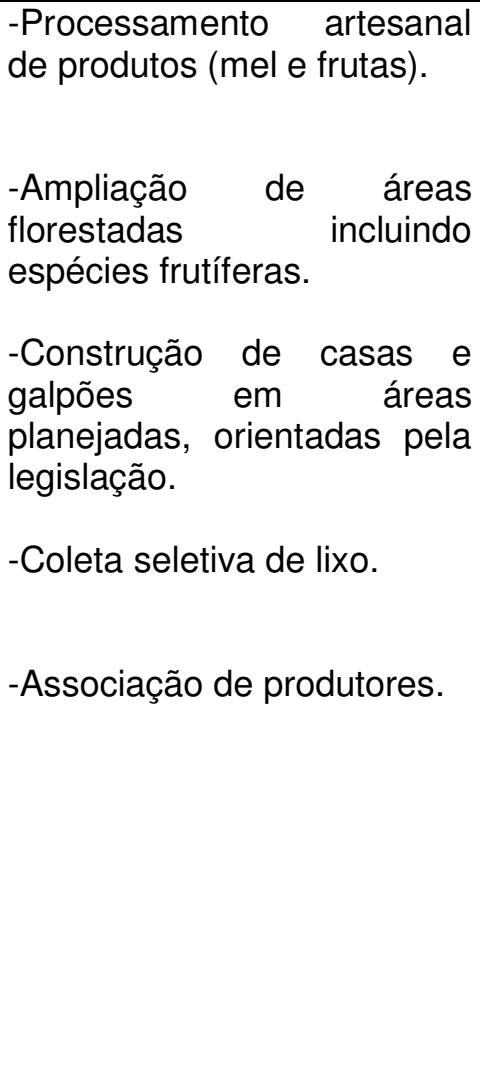 \\
\hline
\end{tabular}


Quanto aos usos proibidos nesta zona, destaca-se a liberação de dejetos de suínos e aves em demasia nas propriedades, os quais passam a contaminar o solo e os recursos hídricos.

O desmatamento em áreas de encostas e nascentes, bem como as atividades voltadas a agricultura sem planejamento e orientação adequada para o uso, são extremamente danosos ao meio ambiente, em função de que nessas áreas o solo é raso e os índices de erosão podem potencialmente se intensificar.

Tolera-se em alguns casos, onde a declividade permite o uso da agricultura e pastagens, respeitando, é claro, as nascentes e cursos d’água. Nesse caso também é tolerada a utilização do espaço consorciando à vegetação com culturas, como o feijão, milho e até a cana de açúcar.

Dentre os projetos levantados pela população para toda a microbacia, o que pode-se orientar para essa zona a partir desse cenário: a ampliação de áreas florestadas, principalmente de espécies nativas, no sistema de silvicultura. Essa prática contribuirá para que todo o sistema se reconstitua, ou seja, que espécies da fauna retornem a este espaço que outrora foi destruído pelos colonizadores.

O processamento artesanal de frutas pode ser incentivado nessa zona, seguido de orientações adequadas com relação ao uso da terra.

A porção abrangida pela ZUOC tem na caracterização da área um relevo que se estende até as declividades de 30\%, aproximadamente. Ocorre a presença de culturas como o milho e fumo de forma bem expressiva, bem como as áreas de pastagens para a alimentação do gado de leite.

Nesta zona tem-se a localização da comunidade de Preferido Alto, Linha Esperança, e a Escola Núcleo com ensino fundamental de pré-escola até a 8ª série. O acesso a área central da microbacia encontra-se em bom estado de conservação, facilitado pelo fluxo de veículos que transportam os alunos matriculados na escola núcleo.

Quanto aos usos proibidos, destaca-se os desmantamentos em áreas de encostas e nas margens dos rios, bem como a liberação de dejetos de aves e suínos, e o uso de agrotóxicos nas lavouras, os quais comprometem a qualidade do solo e da água existente.

São tolerados os usos de agricultura e pastagens em áreas previamente definidas, considerando a legislação ambiental. Assim, as culturas praticadas em áreas com declives suave ondulado a ondulado devem ser manejadas e 
conservadas, controlando a erosão do solo. Ainda com relação ao uso da terra cultura que é intenso nessa zona, pode-se tolerar o uso de vegetação consorciada com as atividades agrícolas, como a cana de açúcar.

Os projetos elencados como prioridade pela população da microbacia são observados no Quadro 17. Partindo-se das prioridades foi elaborado o cenário para a ZUOC, tendo o seguinte: como as áreas classificadas nessa zona encontram-se inseridas em espaços sem muitas restrições de acesso, a implantação de indústrias de processamento de frutas como a laranja, queijo, mel entre outras, tornar-se-ia mais uma das alternativas, para promover o desenvolvimento desse espaço e de toda a microbacia. Antes disso, se faz necessário conhecer as necessidades de mercado e as demandas dos consumidores. O incentivo deve partir de um conjunto, ou seja, a comunidade deve formar grupos de discussão sobre o assunto e os órgãos competentes estaria oferecendo todo o aporte burocrático e de distribuição de tais produtos ao mercado consumidor.

A necessidade de ampliação de áreas florestais também deve ser incentivada, uma vez que contribuirá para a recuperação de algumas áreas degradadas, podendo inclusive, agregar valor dentro das propriedades com o cultivo de espécies frutíferas, como a laranja, cereja, ameixa, entre outras.

A construção de casas e outras bem feitorias nas propriedades devem respeitar as inclinações do relevo.

Outra questão importante, que deve ser destacada, é o papel da escola como formadora de opinião. Esta pode contribuir com a população a partir da elaboração e execução de bons projetos voltados à questão ambiental, na perspectiva de incentivar as pessoas residentes nas adjacências a cuidar melhor do espaço em que vivem, conservando o solo, protegendo as fontes e cursos d’água, entre outros.

Por fim, com base nessa discussão, foi possível espacializar nas microbacias hidrográficas do Lajeado Pirapó e Lajeado Esperança as áreas que apresentam o uso da terra e os conflitos ambientais causados pela intervenção do homem. A partir da delimitação de zonas homogêneas buscou-se projetar e orientar um cenário que viesse a atender as principais demandas ou as perspectivas da população face às características ambientais existentes em cada zona. 
Quadro 17 - Proposta de Zoneamento-Antrópico-Ambiental para a ZUOC na microbacia hidrográfica do Lajeado Esperança-Iporã do Oeste-SC

\begin{tabular}{|c|c|c|c|c|c|}
\hline Zonas & Cenário atual & Usos proibidos & Tolerados & $\begin{array}{l}\text { Projetos levantados e } \\
\text { desejados pela população } \\
\text { para toda a microbacia }\end{array}$ & $\begin{array}{l}\text { Cenário projetado e a } \\
\text { incentivar na ZUOC. }\end{array}$ \\
\hline ZUOC & 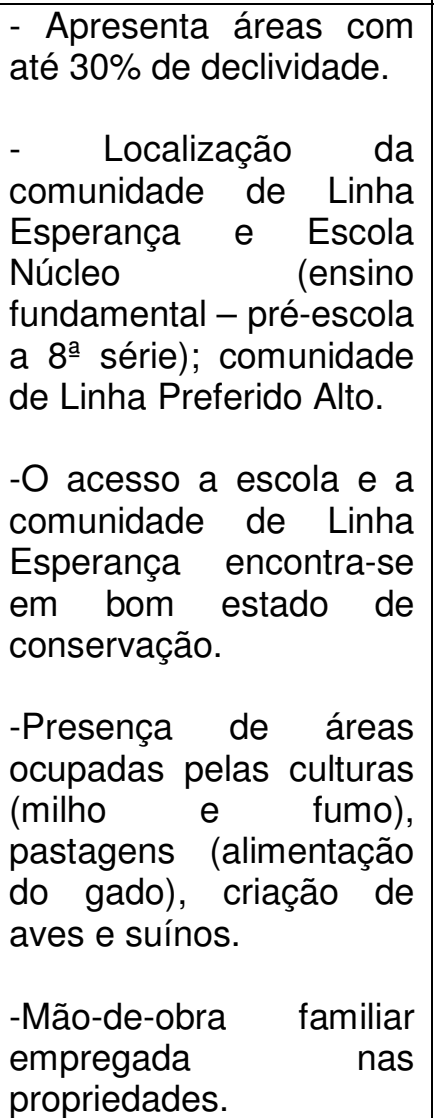 & 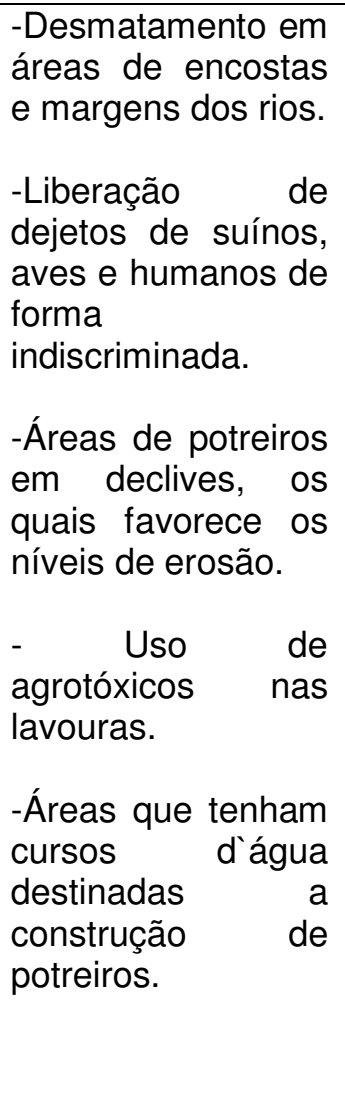 & 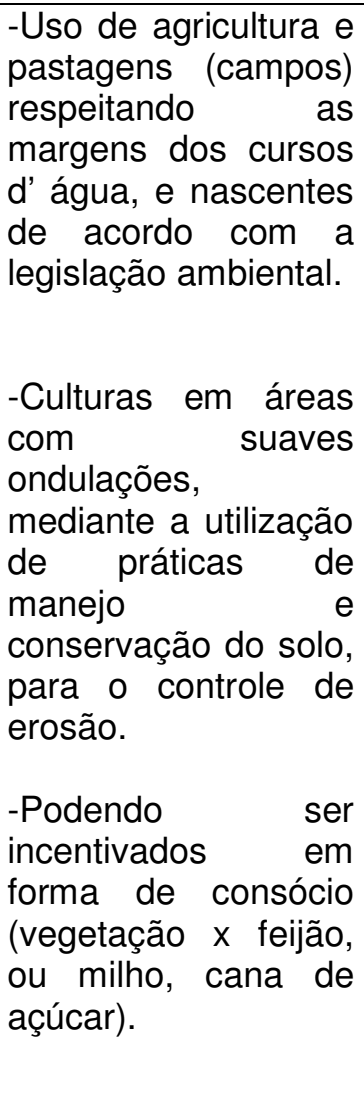 & $\begin{array}{l}\text {-Produção orgânica } \\
\text {-Conservação do solo. } \\
\text {-Habitação. } \\
\text {-Mini-indústria de sucos } \\
\text { concentrados. } \\
\text {-Gado de leite. } \\
\text {-Recuperação e manejo de } \\
\text { florestas e nascentes. } \\
\text {-Coleta seletiva do lixo. } \\
\text { - Associação de produtores. }\end{array}$ & 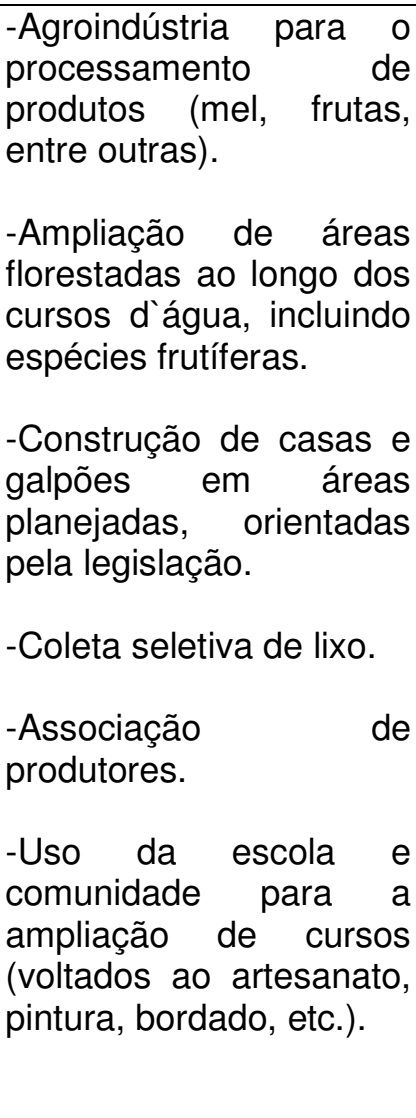 \\
\hline
\end{tabular}


Este cenário projetado, por sua vez, só tornará possível se a comunidade como um todo, juntamente com poder público e órgãos competentes (Epagri, através do microbacias II), realizarem ações conjuntas, com muito diálogo e força de vontade.

\subsubsection{2 - Diretrizes e encaminhamentos gerais}

O Zonemaneto-Antrópico-Ambiental elaborado para as microbacias hidrográficas do Lajeado Pirapó e Lajeado Esperança, buscou integrar e discutir uma série de informações referentes aos fatores socioeconômicos e ambientais. Dessa forma, antes de se adentrar nos encaminhamentos gerais, torna-se pertinente esboçar algumas questões, as quais poderão embasar as políticas de desenvolvimento dentro de cada microbacia estudada, levando em consideração as potencialidades existentes em cada Zona de Uso e Ocupação.

As diretrizes não seguiram um caráter de cunho metodológico específico, porém, foram orientadas nas características físicas, e socioeconômicas existentes no espaço estudado. Nesse contexto, são apresentadas algumas diretrizes, as quais devem ser implementadas, na área de estudo na medida do possível, com o apoio do poder público municipal, por meio de suas secretarias e órgãos competentes, juntamente com a comunidade local, podendo inclusive ser adaptadas, visando os anseios da população e a conservação dos recursos naturais, numa perspectiva de "sustentabilidade".

- A ampliação de projetos de educação ambiental voltadas ao manejo adequado dos recursos naturais nas comunidades e escola pertencentes às microbacias é uma das alternativas. Este tipo de projeto busca qualificar e dinamizar as atividades de produção, aumentando com isso as possibilidades de inserção no mercado, usando os recursos naturais disponíveis de forma adequada e equilibrada. Entende-se que, a busca pelo conhecimento e esclarecimentos de como usar adequadamente a terra faz com que os produtores reduzam as áreas destinadas à produção bem como a pressão sobre o espaço geográfico.

A sensibilização das pessoas pode conduzir a ações de minimização dos impactos ambientais num determinado espaço e formar uma nova consciência, 
promovendo a mudança de valores e de comportamento em relação ao meio ambiente.

- Desenvolver programas de qualificação e aperfeiçoamento para os agricultores, no intuito de qualificar a produção, melhorar o plantel e reduzir os gastos com a criação de gado de leite, suínos e aves.

- Nesse, sentido, também pode ser incentivara criação de pequenos animais como coelhos; hortifrutigranjeiros entre outros.

- Incentivar o cultivo de plantas medicinais, aromáticas e frutas nativas. Esta atividade possibilita a ampliação do conhecimento sobre a biodiversidade da flora existente na região, sem falar da importância das plantas medicinais no tratamento das mais variadas doenças existentes, diminuindo a procura pela assistência médica.

- A implantação da Agenda 21 no município. Essa proposta pode contribuir no avanço das discussões e na implementação de políticas de manejo e recuperação de áreas degradas.

- Monitorar e fiscalizar as áreas de nascentes, pois as mesmas devem estar protegidas para garantir a manutenção dos recursos hídricos.

- Monitorar e controlar os impactos ambientais provocados pela liberação dos dejetos de aves e suínos, evitando assim a contaminação do solo e do lençol freático.

- As atividades de produção deverão estar enquadradas ao que rege as normas do licenciamento ambiental.

- A construção de cisternas para a captação de água é importante, pois as mesmas podem garantir a água para a dessedentação dos animais e plantas em época de estiagem, principalmente para quem tem em suas propriedades aviários e galpões.

- Implementar programas de controle de erosão do solo. Estes devem ser observados em todas as ZUO nas microbacias, uma vez que as declividades existentes podem comprometer a estrutura do solo.

- Desenvolver oficinas ou pequenas áreas para a produção de artesanato, como o crochê, pintura; produtos como o mel e o melado.

- Criar novas áreas de lazer (salão de festas, canchas de bocha e 48), além de melhorar as que já existem, no intuito de promover o bem-estar da população, 
envolvendo-as, resgatando o diálogo e o convívio entre as famílias no interior do município.

- Diante do contexto em que o município se vê inserido, e face aos estudos já realizados, é mister que se oriente a estruturação do plano diretor agrícola, para a dinamização de projetos em todo o território municipal, priorizando ações alternativas que visem o desenvolvimento socioeconômico e a qualidade ambiental.

Nesse sentido, é de fundamental importância o incentivo e o envolvimento do poder público e órgãos competentes na fiscalização bem como envolver a própria população nos projetos, como já vem sendo feito com o Microbacias II. 


\section{6 - CONSIDERAÇÕES FINAIS}

No intuito de contribuir com o planejamento socioambiental do Município de Iporã do Oeste-SC, em especial das microbacias hidrográficas do Lajeado Pirapó e Lajeado Esperança, efetuou-se um estudo aprofundado no que diz respeito ao conhecimento dos padrões de organização do espaço geográfico delimitado. $\mathrm{Da}$ mesma forma, buscou-se levantar e discutir a problemática socioeconômica e ambiental que envolve a área de estudo, propondo algumas alternativas a partir de cenários, os quais orientam a utilização adequada do espaço e a tomada de decisões.

A presente pesquisa desenvolveu-se com base na abordagem sistêmica. Inicialmente, no referencial teórico, elaborou-se um breve resgate sobre o planejamento e a questão ambiental e sua relação com a Geografia, bem como destacou-se a contribuição da abordagem geossistêmica na pesquisa voltada ao planejamento socioespacial.

A metodologia norteadora da pesquisa fundamentou-se na proposta de Libault (1971), o qual aborda os quatro níveis da pesquisa geográfica, atingindo desta forma aos objetivos propostos no trabalho.

Para a elaboração do Zoneamento-Antrópico-Ambiental, é importante destacar a importância das tecnologias computacionais. O Sistema de Informações Geográficas Spring 4.2.1, utilizado para a elaboração dos produtos cartográficos (uso da terra, declividades, hipsometria, legislação, conflitos e zonas homogêneas) mostrou-se eficiente não só pela rapidez e facilidade de manusear um grande conjunto de dados, mas também, pela estruturação de um banco de dados georreferenciados, os quais servirão como fonte para pesquisas futuras, possibilitando estudos sobre a dinâmica espacial e elaboração de um plano diretor para o município.

Entretanto, conhecendo a dinâmica de elaboração dos produtos por meio do SIG-Sring, e buscando apresentar os produtos finais com uma boa definição, estes foram editados do Corel Draw 12.

A escala cartográfica adotada para a elaboração dos produtos insere-se na classificação de semidetalhe (1:40.000) conforme o IBGE (1999), sendo considerada compatível aos objetivos da pesquisa. 
Diante dos dados levantados e analisados, pode-se dizer que o Município de Iporã do Oeste caracteriza-se por ser essencialmente agrícola, com destaque a produção de milho, feijão e fumo, bem como a criação de aves, suínos e gado de leite. Por se tratar de um município que tem na sua base a produção agropecuária, as propriedades classificam-se em média de 12 a 15 ha, com a utilização da mãode-obra essencialmente familiar. Diante disso vale destacar ainda, que $63,80 \%$ da população reside na zona rural.

Para o mapeamento de uso da terra foram definidas as seguintes classes de uso da terra: culturas, florestas, campos, área urbana e não classificados, isto para os mapeamentos dos períodos de 1978 e 1997, acrescentando a classe de uso água para o mapeamento de uso da terra de 2007, eliminando assim, a classe de uso não classificado, por não ser constada na imagem. Assim, pôde-se verificar que o uso da terra predominante no município é o das culturas, principalmente no que se refere ao ano de 1997, ocupando 58,3\%, da área do município. No ano de 2007, esta classe cai para uma área de $9.238,73$ ha, $46,17 \%$ do total do total da área do município de Iporã do Oeste, que é de 20.009,62 ha. As áreas de culturas cedem espaço para as áreas florestadas, face ao abandono de algumas propriedades e a aplicação da legislação ambiental.

No que diz respeito às declividades no município pode-se dizer que as áreas planas abrangem apenas $9,7 \%$ da área total, contra $52,9 \%$ de área com declividades acima declividades acima de $30 \%$.

Nesse contexto, Spironello (2002) destaca que, face às características topográficas no município, a condição do produtor e a falta de uma política agrícola de incentivo a diversificação das atividades no campo e de manejo adequado dos recursos naturais, fazem com que o pequeno proprietário utilize de forma inadequada o espaço geográfico. O pequeno proprietário de terras sente-se obrigado de ocupar além das poucas áreas planas existentes, outras áreas com declives acentuados a fim de garantir a sua permanência e a da sua família na agricultura.

Partindo dessa contextualização buscou-se elaborar o ZoneamentoAntrópico-Ambiental (ZAA) em duas áreas amostrais, com características peculiaridades; as microbacias hidrográficas do Lajeado Pirapó (MHLP) e Lajeado Esperança (MHLE). As zonas foram estabelecidas com base na metodologia de Rocha (1997), delimitando as áreas homogêneas a partir das características do 
relevo, hipsométricas, legislação e uso da terra. O conhecimento e a experiência da pesquisadora sobre a área de estudo contribuiu para melhor delimitar as áreas e discutir sobre o cenário atual caracterizado.

A partir da sobreposição dos planos de informação, foi possível elaborar, inicialmente, o Zoneamento Ambiental com a caracterização de três zonas homogêneas, a saber: a Zona de Uso e Ocupação Moderada (ZUOM), Zona de Uso e Ocupação Restrita (ZUOR) e Zona de Uso e Ocupação Controlada (ZUOC). Assim, a partir da análise de cada uma das zonas estabelecidas no que se refere aos fatores físicos econômicos e sociais, foi possível configurar, os cenários atuais e a incentivar em cada ZUO nas microbacias.

Vale destacar, no entanto que os relatórios elaborados sobre a realidade socioeconômica e ambiental das microbacias em estudo, foram fundamentais para as análises e discussões desta pesquisa, pois a partir das perspectivas e projetos da população da MHLP e MHLE, foi possível fazer uma ponte entre o cenário atual (com base no zoneamento ambiental) e o desejado pela população, resultando assim numa proposta de cenários a incentivar, guiados por algumas diretrizes principais, como: implementação de projetos de educação ambiental; monitoramento e controle de impactos ambientais, principalmente em áreas de nascentes e encostas; cursos de aperfeiçoamento e qualidade de produção na agricultura; cursos de manejo e conservação do solo; construção de cisternas para a captação de água; incentivar a implantação da Agenda 21 e do plano diretor agrícola, no sentido de dinamizar as políticas públicas e as tomadas de decisões em cada setor. As diretrizes só serão possíveis de serem implementadas com o incentivo do poder público municipal e a orientação técnica dos órgãos competentes dentro do território municipal e a participação efetiva da população. 


\section{BIBLIOGRAFIA}

AB' SABER, A. Os domínios de natureza no Brasil. Potencialidades paisagísticas. São Paulo: Ateliê Editorial, 2003.

AURÉLIO, B. H. F. Novo Dicionário Aurélio. Rio de Janeiro: $3^{\underline{a}}$ ed., 5.0 Versão, Editora Positivo, 2004, Cd-Rom.

ATLAS DE SANTA CATARINA. Florianópolis: IBGE, 1989.

BERTRAND, G. Paisagem e Geografia Física Global - Esboço metodológico. Cadernos de Ciências da Terra. São Paulo, nº 13, 1971.

BOTELHO, R. Planejamento Ambiental em Bacias Hidrográficas. In: GUERRA, A. T. et al. Erosão e conservação dos solos: conceitos, temas e aplicações. Rio de Janeiro: Bertrand Brasil, 1999.

BOTELHO, R. \& SILVA. Planejamento ambiental em bacias hidrográficas. In: VITTE, A. C. \& A. J. T. GUERRA. Reflexões sobre a Geografia Física no Brasil. Rio de Janeiro: Bertrand Brasil, 2004.

CASSOL, R. Zoneamento ambiental elaborado com variáveis otimizadas estatisticamente, geradas por técnicas cartográficas. 1996. Tese (Doutorado em Geografia Humana) - Universidade de São Paulo, São Paulo. 1996.

CHRISTOFOLETTI, A. Geomorfologia. São Paulo: Edgard Blücher, ed da USP, 1974.

Análise de Sistemas em Geografia. São Paulo: Hucitec, 1979.

Modelagem de Sistemas Ambientais. São Paulo: Edgard

Blücher, 1999. 
CRÓSTA, A. P. Processamento digital de imagens de sensoriamento remoto. Campinas: IG/INICAMP, 1993.

DE BIASI, M. A Carta Clinográfica. Os Métodos de Representação e sua Confecção. Revista do Departamento de Geografia. São Paulo: FFLCH/USP, n0 6, 1992.

DEL PRETTE, M. E. Zoneamento-ecológico-economico. Ministério do Meio Ambiente, 2007.

EMBRAPA. Sistema de avaliação da aptidão agrícola das terras. RAMALHO, $\mathrm{F}$. A. \& BEEK, K.J. Rio de Janeiro: 3ª ed. rev. EMBRAPA/CNPS, 1995.

EPAGRI - EMPRESA DE PESQUISA AGROPECUÁRIA E EXTENSÃO RURAL DE SANTA CATARINA S.A. Zoneamento agroecológico e socioeconômico de Santa Catarina. Florianópolis, Epagri, 1999.

FARAH, M. F. S. \& BARBOZA, H. B. Novas experiências de gestão pública e cidadania: Projeto de recuperação, conservação e manejo dos recursos naturais em bacias hidrográficas. Rio de Janeiro: Editora FGV, 2000. http://inovando.fgvsp.br/conteudo/documentos/20experiencias1999/16\%2020microbacias.pdf. Acesso em 21/10/05.

FONTANA, A. (org) Construindo a sustentabilidade: uma perspectiva para o desenvolvimento regional. São Miguel do Oeste: McLee, 2001.

FUNDAÇÃO DE AMPARO Á TECNOLOGIA E MEIO AMBIENTE - FATMA. Mapa Fitogeográfico. 1978.

FRANCO, M. A. R. Planejamento ambiental para a cidade sustentável. São Paulo: Annablume, $2^{\underline{a}}$ ed., 2001.

INSTITUTO DE PLANEJAMENTO E ECONOMIA AGRÍCOLA. Colonização e evolução econômica: breves considerações - oeste catarinense. Florianópolis: Secretaria do Estado e Desenvolvimento e da Agricultura, 1990. 
Estudo preliminar dos solos do oeste catarinense classes para irrigação; classes para aptidão agrícola. Florianópolis: Secretaria do Estado e Desenvolvimento e da Agricultura, 1990.

Recursos naturais - oeste catarinense. Florianópolis:

Secretaria de Estado e Desenvolvimento Rural, 1994.

INSTITUO BRASILEIRO DE GEOGRAFIA E ESTATístICA - IBGE. População. Disponível

em:

http://www.ibge.gov.br/ibge/estatistica/população/censo2000/consulta.php/paginaatu $\underline{\mathrm{al}=1 \& u \mathrm{f}=42 \& \mathrm{letra}=\mathrm{i}}$. Acesso em 05 de Janeiro de 2005.

JUNGBLUT, R. Documentário Histórico de Porto Novo. São Miguel do Oeste: Arco Íris Gráfica e Editora, 2000.

KARNAUKHOVA, E. A análise geossistêmica da paisagem e as suas potencialidades para gestão ambiental das bacias hidrográficas com elevado grau de degradação ambiental. In: IV SIMPÓSIO NACIONAL: RECUPERAÇAO DE ÁREAS DEGRADADAS “SILVICULTURA AMBIENTAL”. FURB, 2000.

LANNA, A. E. L Gerenciamento de bacia hidrográfica: aspectos conceituais e metodológicos. Brasília: Instituto Brasileiro do Meio Ambiente e dos Recursos Renováveis. 1995.171p.

Levantamento agropecuário de Santa Catarina 2002-2003. Florianópolis: Secretaria do Estado e Desenvolvimento Rural. 2005.

LIBAULT, A. As tendências atuais da Cartografia. Boletim Paulista de Geografia. São Paulo: AGB/SP, $n^{0}$ 44, 1967.

Os Quatro Níveis da Pesquisa Geográfica. Métodos em Questão. São Paulo: IGEO/USP, n 1, 1971. 
MACHADO, P. A. L. Direito Ambiental Brasileiro. São Paulo: $7^{a}$ Edição, Editora Malheiros Editores, 1999.

MELO, D. R. de Geossistemas: Sistemas Territoriais. Disponível em: < http://ivairr.sites.uol.com.br/dirce.htm> Acesso em 18/09/04.

MENDONÇA, F. A. Geografia e Meio Ambiente. São Paulo: Contexto, 1998.

- Diagnóstico e analise ambiental de microbacia hidrográfica:

Proposição metodológica na perspectiva do zoneamento, planejamento e gestão ambiental. Revista o Espaço Geográfico em Análise. Curitiba: $n^{0} 3$, ano 3, v.1, 2000.

Geossistemas: A história de uma procura. São Paulo:

Contexto, 2000.

MISSIO, E. Proposta Conceitual de Zoneamento Ecológico-Econômico para o Município de Frederico Westphalen - RS. Tese (Tese de Doutorado) Universidade Federal de São Carlos/SP. 2003.

MONTEIRO, C. A. F. A Questão Ambiental: 1960-1980. São Paulo: Instituto de Geografia, 1981.

MORAES, A. C. R. Meio Ambiente e Ciências Humanas. São Paulo: Hucitec, 1994.

Geografia: Pequena História Crítica. São Paulo: Hucitec, $18^{a}$ ed. 2002.

PHILIPPI JR, A. (et al). Municípios e Meio Ambiente: Perspectivas para a Municipalização da Gestão Ambiental no Brasil. São Paulo: ANAMMA, 1999.

PIAZZA, W. F. Santa Catarina: Sua História. Florianópolis: Ed. da UFSC, 1983. 
A Colonização de Santa Catarina. $3^{\mathrm{a}}$ ed. Florianópolis: Lunardelli, c1994.

PUNDEK, M \& MOLINARI, A. J. Curso de Identificação, Uso e Manejo dos Solos da Região Oeste de Santa Catarina. EPAGRI, 2001.

REGULAMENTO DA 1로 FAIC. Folha 1, 1972.

ROCHA, J. S. M. da. Manual de Projetos Ambientais. Santa Maria: Imprensa Universitária, 1997.

ROSA, R. O Uso do SIG's para o Zoneamento: Uma Abordagem Metodológica. 1995. Tese (Doutorado em geografia Física) - Universidade de São Paulo, São Paulo, 1995.

ROSS, J. L. S. Análises e síntese na abordagem geográfica da pesquisa para o planejamento ambiental. Revista do Departamento de Geografia. São Paulo: FFLCH/USP, n 9, 1992.

ROSS, J. L. S. (org). Geografia do Brasil. São Paulo: Editora Edusp, 1995. Geomorfologia: Ambiente e Planejamento. $6^{a}$ ed. São Paulo: Contexto, 2001.

SANCHÉZ, P. O. \& SILVA, T. C. Zoneamento ambiental: uma estratégia de ordenamento da paisagem. Rio de Janeiro: Caderno Geociências, $n^{0}$ 14:47-53, abril/junho, 1995.

SECRETARIA DE EDUCAÇÃO, CULTURA, DESPORTO E TURISMO. Iporã do Oeste - 1925/1997. Iporã do Oeste: 1998.

SILVA, J. W. O Oeste Catarinense: memórias de um pioneiro. Florianópolis: Edição do autor, 1987. 
SILVA, J. S. V. da \& SANTOS, R. F. dos. Zoneamento para planejamento ambiental: vantagens e restrições de métodos e técnicas. In: Cadernos de Ciência \& Tecnologia. Brasília, Embrapa, v.21, n 2, p. 221-263, maio/ago, 2004.

SMANIO, G. P. Interesses difusos e coletivos: Estatuto da criança e do adolescente, consumidor, meio ambiente e improbidade administrativa, ação civil pública e inquérito civil. São Paulo: Atlas, 1999.

SOTCHAVA, V. B. O Estudo de Geossistemas. Métodos em Questão. São Paulo: FFLCH/USP, $n^{0} 16,1977$.

SPIRITO SANTO, E. A agricultura no Estado de Santa Catarina. Chapecó: Grifos, 1999.

SPIRONELLO, R. L. Relatório técnico de execução relativo a convênio firmado entre prefeitura Municipal de Iporã do Oeste-SC e Universidade Federal de Santa Maria-RS. Santa Maria: 1999.

Mapeamento do uso da terra em função das classes de declividades no Município de Iporã do Oeste/SC. 2001. Monografia (Monografia de Especialização) - Universidade Federal de Santa Maria, Santa Maria. 2001.

Adequabilidade do uso da terra no município de Iporã do Oeste-SC: Uma análise geossistêmica da Microbacia do Arroio Taquarussu. Dissertação (Dissertação de Mestrado) - Universidade de São Paulo/SP. 2002.

SCRURAL. Jornal local. Iporã do Oeste. 2002.

TRICART, J. Paysage et ecologie. Revista Geomorph Dynam... XXVIII, Paris: (3): 81-95 [1977].

TROPPMAIR, H. Geossistema: enfoque de integração. Revista de estudos ambientais. Blumenau, v.2, n 2-3, 34-40, mai/dez, 2000. 
VIEIRA, P. F. (et all). Meio Ambiente, desenvolvimento e cidadania: desafios para as ciências sociais. Florianópolis: Ed da UFSC, 1995.

WANDERLEY, L. L. Litoral Sul de Sergipe uma Proposta de Proteção Ambiental e Desenvolvimento Sustentável. 1998. Tese (Doutorado em Organização do Espaço) - Universidade Estadual Paulista, Rio Claro. 1998. 
